Portland State University

PDXScholar

8-20-1976

\title{
Biostratigraphy of the Snowshoe Formation (Jurassic) in the Izee area, Grant County, Oregon
}

\author{
Paul Lawrence Smith \\ Portland State University
}

Follow this and additional works at: https://pdxscholar.library.pdx.edu/open_access_etds

Part of the Geology Commons, and the Paleontology Commons

Let us know how access to this document benefits you.

\section{Recommended Citation}

Smith, Paul Lawrence, "Biostratigraphy of the Snowshoe Formation (Jurassic) in the Izee area, Grant County, Oregon" (1976). Dissertations and Theses. Paper 2416.

https://doi.org/10.15760/etd.2413

This Thesis is brought to you for free and open access. It has been accepted for inclusion in Dissertations and Theses by an authorized administrator of PDXScholar. Please contact us if we can make this document more accessible: pdxscholar@pdx.edu. 
BIOSTRATIGRAPHY OF THE SNOWSHOE FORMATION (JURASSIC)

IN THE IZEE AREA, GRANT COUNTY, OREGON

by

PAUL L. SMITH

A thesis submitted in partial fulfillment of the requirements for the degree of

MASTER OF SCIENCE

in

GEOLOGY

Portland State University

1976 
AN ABSTRACT OF THE THESIS OF Paul L. Smith for the Master of Science in Geology presented August 20, 1976.

Title: Biostratigraphy of the Snowshoe Formation (Jurassic) in the Izee area, Grant County, Oregon.

APPROVED BY MEMBERS OF THE THESIS COMMITTEE:

Richard E. Thoms, Chairman

Marvin H. Beeson

Joseph J. Kohut

Using the standard Jurassic zonal scheme, this work attempts to determine the ages of the four members of the Snowshoe Formation that crop out in the Izee area. As a corollary, regional correlations are possible. The 
stratigraphic relationship between the Snowshoe Formation, the subjacent Hyde Formation and the superjacent Trowbridge Formation is also investigated.

Over one thousand fossils were collected from five stratigraphic sections and eight localities. The sections were measured using tape and compass techniques and the relative stratigraphic ranges of the fossils calculated using a computer program written specifically for this project. The ammonite fauna, dominated by the families Hildoceratidae, Stephanoceratidae and Sonniniidae, is systematically described.

The Snowshoe Formation was deposited in marine waters of neritic depths during late Toarcian to early Callovian time, with the Bathonian apparently unrepresented. The lower member correlates in part with the Weberg and Warm Springs Members of the Snowshoe Formation in the Suplee area whereas the middle and Silvies members correlate in part with the Basey Member. Most of the Snowshoe Formation has, or probably has, correlatives within the North American continent. The lower contact of the Snowshoe Formation in the Izee area is gradational and the basal deposits non-diachronous whereas the upper contact is either diachronous or represents an unconformity. 
TO THE OFFICE OF GRADUATE STUDIES AND RESEARCH:

The members of the Committee approve the thesis of Paul L. Smith presented August 20, 1976.

Richard E. Thoms, Chairman

Marvin H. Beeson

Joseph J. Kohut

APPROVED :

Marvin H. Beeson, Head, Department of Earth Sciences

David T. Clark, Dean of Graduate Studies and Research 


\section{ACKNOWLEDGEMENTS}

I would like to thank Mr. Tom Amundson for his tireless help as a field companion during both the field seasons of 1974 and 1975.

I am most grateful to Dr. R. W. Imlay of the

United States Geological survey who provided references, maps, plastotypes and valuable advice. Several very rewarding days were spent in the field with Dr. Imlay during 1975 exploring various aspects of the Jurassic succession in eastern Oregon.

Dr. Richard Thoms was my advisor during my graduate studies at Portland State University. I would like to thank him, not only for his help in a professional capacity, but also for making me feel at home in a new country. Other members of the faculty at Portland state University who offered their assistance at various stages of my thesis research include Dr. Van Atta, Dr. Kohut, Dr. Johnson and Mr. Pierson. Mr. Ric Bartlett of the Earth Sciences Museum at Portland State University assisted with the preparation of some of the specimens.

Dr. N. Morton of the University of London, England provided several publications and allowed me to view his collection of sonninids from western Scotland. Dr. G. E. G. Westermann of McMaster University, Canada sent me several 
of his publications. Mr. David Taylor, a graduate student at the University of California, Berkeley, helped me immensely in supplying obscure publications and discussing the many problems of ammonite taxonomy as well as accompanying me in the field on various occasions. Mr. Arden Callender, Jr. offered advice, valuable criticism and consolation when the occasion arose. My thanks to all these gentlemen.

Several ranchers and ranch managers allowed me access to their lands. I am particularly grateful to Mr. Owen Martin of the Izee Ranch and to Mrs. Hyde, owner of the Hyde Ranch.

The photographs of the fossils were taken by Ms. Kathy Gordanier-Smith and the films developed and printed by the Audio-Visual Department at Portland State University. Finally, I would like to thank my family: my parents for their encouragement and my wife, Kathy, whose unfailing help and support during the preparation of this paper made its completion possible. 
TABLE OF CONTENTS

PAGE

ACKNOWLEDGEMENTS ............ . . .

IIST OF TABLES . . . . . . . . . . . vii vi vi

LIST OF FIGURES • . . . . . . . . • • viii

INTRODUCTION . . . . . . . . . . . . . 1

GEOLOGY . . . . . . . . . . . . . 3

Introduction ........... 3

The Snowshoe Formation ........ 7

PALEONTOLOGY . . . . . . . . . . . . 12

Ammonites ............. 12

Other Fossils . . . . . . . . 32

BIOSTRATIGRAPHY ................. 35

Age and Correlation - The Lower Member . . 43

Age and Correlation - The Middle Member . . 47

Age and Correlation - The Silvies Member . . 49

Age and Correlation - The Upper Member . . 50

Paleoecology ................. 51

Conclusions . . . . . . . . . 55

SYSTEMATIC SECTION . . . . . . . . . . 64

Notes on Preservation and Quantification . . 64

Systematic Descriptions . . . . . . 68 
vi

PAGE

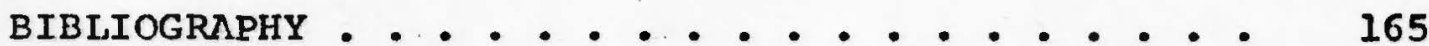

PINTES ...................... 177

APPENDIX A - SECTION AND LOCALITY DESCRIPTIONS • • 198

APPENDIX B - FORTRAN IV PROGRAM STRAT . . . . . 201

APPENDIX C - FOSSIL CATALOG NUMBERS . . . . 212 
LIST OF TABLES

PAGE

TABLE

I Ammonite Genera and Subgenera from

the Snowshoe Formation Showing

Biological Relationships and

Number of Specimens Available

for Study . . . . . . . . . 14

II Geographic Distribution of the

Snowshoe Formation Fauna in

the Izee Area . . . . . . . 15 


\section{LIST OF FIGURES}

PAGE

FIGURE

1 Simplified Geologic Map of the Izee

Area Showing Sections Measured

and Fossil Localities . . . . Pocket

2 Lithostratigraphy of the Snowshoe

Formation in the Izee Area . . . 8

3 Histogram Showing the Distribution

by Family of the Snowshoe

Formation Ammonite Fauna . . . . 13

4 The Stratigraphic Range of Dumortieria

Haug and CatulZoceras Gemmellaro

in Northwest Europe ana Southern

France . . . . . . . . . . 24

5 Standard Zones of the European

Jurassic . . . . . . . . 36

6 Section 1 (Big Flat) - Biostratigraphy

and Lithostratigraphy . . . . . 38

7 Section 2 (Flat Creek) - Biostrati-

graphy and Lithostratigraphy . .

8 Section 3 (Bunton Hollow) - Biostra-

tigraphy and Lithostratigraphy . Pocket 
FIGURE

9 Section 4 (Sheep Creek Divide) Biostratigraphy and Lithostratigraphy ..........

10 Section 5 (Caps Creek) - Biostrati-

graphy and Lithostratigraphy . . Pocket

11 Stratigraphic Section of the Type

Silvies Member Showing Fossil

Localities . . . . . . . .

12 The Age of the Snowshoe Formation

in the Izee Area ........

13 Correlation of Members of the

Snowshoe Formation in the Izee

Areas . . . . . . . . . . .

14 The Umbilical Diameter of Ammonites . .

15 Rib Densities for Dumortieria

insignisimilis (Brauns) and

Dumortieria cf. D. dumortieri

(Thiollière) - Section Four . . •

16 Dumortieria ? cf. D. pusilza Jaworski:

Variation of Ribbing Density

During Ontogeny ........

17 Tmetoceras scissum (Eenecke): Varia-

tion of Ribbing Density During

Ontogeny ........... 
PAGE

\section{FIGURE}

18 Sketches Showing the Variety of

Lappets Displayed by Species of

Pelekodites from the Izee Area . . 124

19 Comparisons of Some of the Type

Material of Stephanoceras (Skirro-

ceras) juhlei Imlay and Stephanoceras

(Skirroceras) kirschneri Imlay . . 141

20 Variables for Program Strat . . . . 202

21 Model Illustrating Parameters Used

in Program Strat . . . . . . 202

22 Program Response to Various Values

of ANGA . • . . . . . . . . 203

23 Examples Illustrating the Calculation

of Fossil Positions Using Program

strat . . . . . . . . . 209 


\section{INTRODUCTION}

In the western Blue Mountains of eastern Oregon there occurs an extensive inlier of Paleozoic and Mesozoic rocks. Part of the immensely thick Jurassic portion of this sedimentary pile, named the Snowshoe Formation, crops out discontinuously over a wide area stretching from the Silvies River valley, Grant County, in the north to the Emigrant Creek area, Harney County, in the south. Exposures of the Snowshoe Formation in the suplee area to the west are separated from easterly exposures in the Izee and Seneca areas by the Mowich upwarp. This report is concerned with the Snowshoe Formation where it is exposed on the eastern flank of the Mowich upwarp near the former town of Izee (see fig. 1).

Fossil collections were made during the summers of 1974 and 1975 along the entire strike of the snowshoe Formation in the Izee area as mapped by Dickinson (1958; Dickinson and Vigrass, 1965). Sections were measured, using compass and tape techniques, at five locations within this area and fossils collected or obtained from eight localities (see fig. 1 and Appendix A). In excess of a thousand samples yielded over six hundred identifiable ammonites and sundry other fossils. The stratigraphic position of each specimen was calculated 
using a computer program written by the author. A copy of this program and the necessary documentation is included (Appendix B).

This study was undertaken to establish more clearly the age of the Snowshoe Formation and its biostratigraphic relationship to the subjacent Hyde Formation and superjacent Trowbridge Formation. Complex facies relationships between the Silvies Member and the informally named lower, middle and upper members of the Snowshoe Formation were also investigated.

The Izee area itself is important in evaluating the biostratigraphy of the Snowshoe Formation because it is at the geographic center of the total area of outcrop and shows the maximum development of the Formation in terms of age. Furthermore, the Izee area does not show the tectonic complications evident further to the east around Seneca where Cretaceous intrusions have caused the added difficulty of contact metamorphism. With a detailed knowledge of the biostratigraphy of the Snowshoe Formation in the Izee district, which contains the type areas for both the Snowshoe Formation and the Silvies Member of the Snowshoe Formation, the tectonic problems to the east should be more easily resolved.

This work also adds useful information to the body of knowledge concerned with global ammonite distributions during the Jurassic Period. 


\section{GEOLOGY}

Introduction

The Snowshoe Formation, subjacent and superjacent Jurassic deposits in the Izee area strike northeastsouthwest along the eastern flank of the Mowich upwarp and dip steeply to the southeast. The Formation is traversed by the South Fork of the John Day River around the former community of Izee, where the type area was designated by Lupher (1941, p. 259) . Exposures everywhere are generally poor and this is particulary true for the type area.

To the southwest of Izee the Snowshoe Formation can be traced around the flank of the Mowich upwarp to the eastern half of section $32, T .18 \mathrm{~S}$, , R. $26 \mathrm{E}$. where it disappears beneath a cover of Cenozoic volcanic rocks. Dickinson and Vigrass (1965, p. 44) have since demonstrated that deposits cropping out around the abandoned town of Suplee and separated from the Izee area to the east by the Mowich upwarp, are shallower water facies equivalents of the type snowshoe Formation. Since these deposits are areally limited they were incorporated into the snowshoe Formation as the Weberg, Warm Springs and Basey members by Dickinson and Vigrass (20c. cit.) as a simplification of Lupher's terminology. 
To the northeast of Izee a thick volcaniclastic unit named the Silvies Member (Dickinson and Vigrass, 1965, p. 49) interdigitates with sedimentary rocks of the middle part of the Snowshoe Formation. Snowshoe sedimentary rocks have been traced some eighteen miles beyond the area of study eastward toward Seneca (Brown and Thayer, 1966) where the Silvies Member reaches a thickness in excess of 5,000 feet (c. 1,524 meters) and includes andesitic lavas (Dickinson and Vigrass, 1964, p. 51,59$)$.

For the purposes of this study the Izee area is defined as the area covered by the geologic maps of Dickinson (1958; Dickinson and Vigrass, 1965). Throughout this area, the Snowshoe Formation rests conformably on the Hyde Formation, the uppermost unit of the Mowich Group. The Hyde Formation is composed of thick beds of blue gray andesitic marine tuff and tuffaceous volcanic graywacke which weathers greenish brown (Dickinson and Vigrass, 1965, p. 41). The unit, which is unfossiliferous, forms an admirable base to all the sections measured since it is highly resistant, particularly in comparison to the easily eroded argillaceous sedimentary rocks of the lower Snowshoe Formation. Consequently, the Hyde Formation crops out as crags on the western banks of subsequent streams (tributaries of the South Fork of the John Day River) whose courses are guided by the outcrop 
of the Snowshoe Formation. The contact between the two formations is somewhat gradational over a stratigraphic interval of less than 20 feet (c. 6.1 meters) but the contact is easily drawn at the top of the stratigraphically highest sandstone bed in a continuous sequence. The contact between the Snowshoe Formation and the overlying Trowbridge Formation is not conformable but if any angular discordance exists it is too small to be discernable. The Trowbridge Formation is divided into three members. The lowermost, the Rosebud Member, is composed of massive to faintly bedded, black to green, faintly laminated mudstone. It thins to the southwest and does not reach Big Flat so that the overlying officer Member comes to lie directly on the Snowshoe Formation in this area. The officer Member is composed of alternations of Rosebud-like mudstones and resistant, ledge-forming, volcaniclastic rocks. The latter are diagenetically altered tuffs and volcanic sandstones. For detailed descriptions of the petrology and discussions of the significance of all the Jurassic rocks in the Izee area, the interested reader is referred to the works of Lupher (1941), Dickinson (1958, 1962a, 1962b, 1962c) and Dickinson and Vigrass $(1964,1965)$

Tracing the Snowshoe Formation along strike from southwest to northeast within the Izee area, the outcrop is seen to widen considerably. The most southerly section 
measured (Section 1) yielded a total stratigraphic thickness for the Formation of 1,485 feet (c. 453 meters) whereas in the north (Section 3) a stratigraphic thickness of 3,200 feet (c. 975 meters) was measured, with an estimated 1,000 feet (c. 305 meters) of the upper part of the sequence not seen. At Caps Creek (Section 5), between these two extreme localities, a total stratigraphic thickness of 2,370 feet (c. 722 meters) was obtained. This represents a thickening at the rate of 120 feet per mile from Section 1 to Section 5 and approximately three times that rate between sections 5 and 3 .

Structurally, the southern part of the area is more simple, with shallower dips and only a few major normal faults. To the north the dips become much steeper and, in the most northerly part of the area, the rocks are tightly folded into the northeast-southwest trending Tamarack anticline and Lewis syncline. Section 3 was measured between the axes of these two folds and it is tempting to attribute the thickening to drag folding (cf. Dickinson, 1958, p. 115). The lower part of this section is well exposed and no such complications are evident but in the poorly exposed upper part, near the axis of the Lewis syncline, drag folding is a possibility, suggested by locally anomolous dips. However, it will be later reasoned that any tectonic thickening is merely in addition to the thickening attributable to stratigraphic and sedimentologic 
causes (see p. 62).

The Snowshoe Formation

In 1965 Dickinson divided the type Snowshoe Formation of Lupher's terminology into three gradational, lithologically distinctive but unmapped and informally recognized lower, middle and upper members (Dickinson and Vigrass, 1965, p. 44). These are very useful divisions but they are retained as informal members because their contacts are occasionally diffuse. The relative thicknesses and relationships between these three members and the Silvies Member in the Izee area is shown in fig. 2. Iithological features of the sequence are shown in the stratigraphic columns contained in the biostratigraphic section of this work (figs. 6 to 11 ).

It should be noted that in no section measured during this study did the lower, middle and upper members follow each other in uninterrupted stratigraphic sequence. Either the upper member was missing or the Silvies Member separated, or probably separated, the middle and upper members.

Where the upper contact is fairly clear (sections 1 and 3), the lower member is seen to maintain a constant thickness (630 feet, c. 192 meters) over much of the area. However, the contact on section 5 is diffuse, spanning a stratigraphic interval of 200 feet (c. 61 meters) so that the lithology of the middle member is not dominant until 


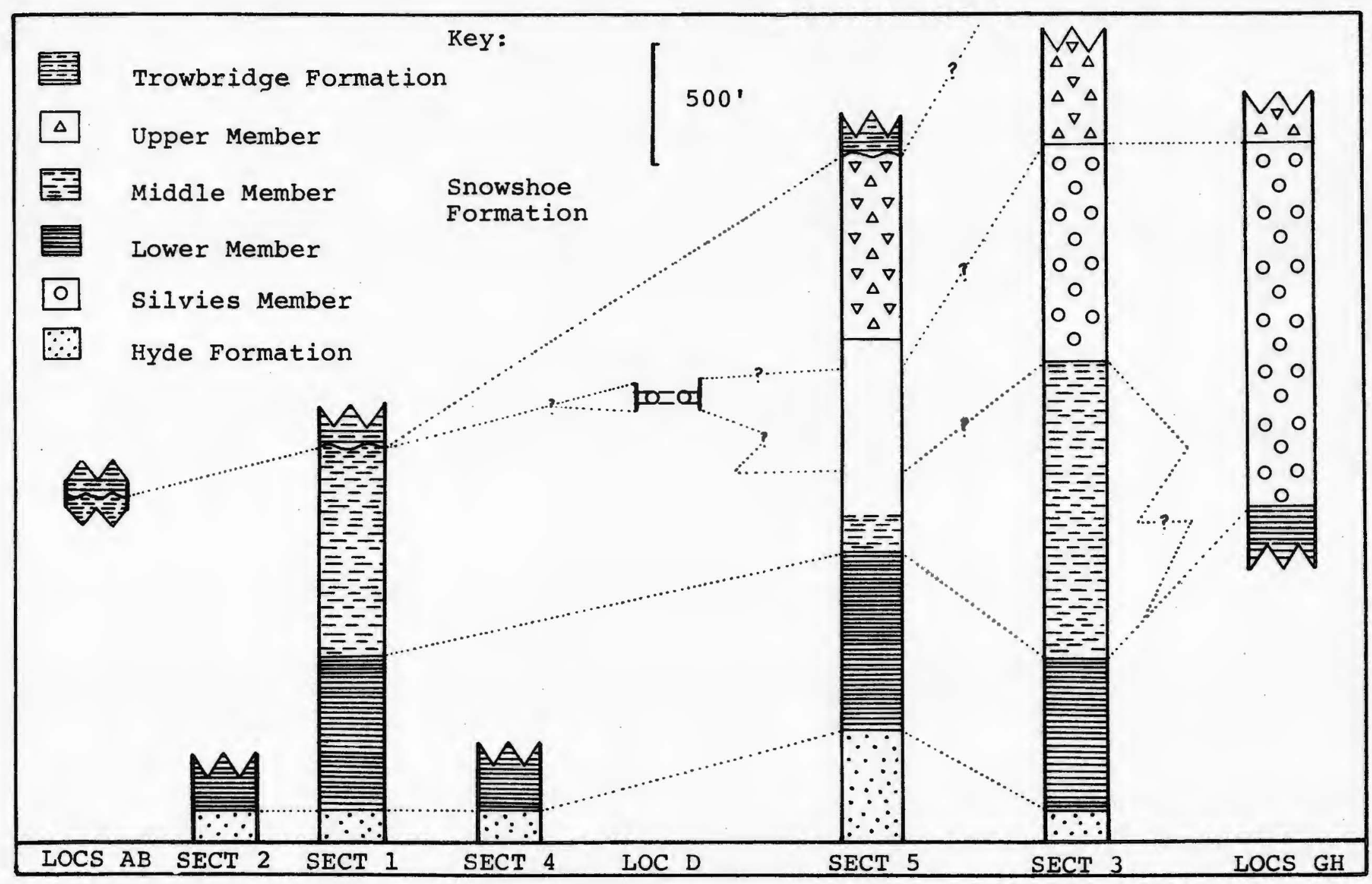

Figure 2. Lithostratigraphy of the Snowshoe Formation in the Izee area. 
the lower member has reached a thickness of 725 feet (c. 221 meters).

The lower member is composed of brown and dark gray to black, thin-bedded mudstone, shale and siltstone. The siltstones are usually predominant in the basal part of the member, especially in Section 4. Most of these argillaceous rocks are calcareous and calcareous nodules are evident in sections 3 and 5 . The nodules are diagenetic and characterized by their silty laminae being etched into relief on weathered surfaces. Limestones are developed in the lower member at 50 to 100 foot intervals in all of the sections measured except section 4. These limestones may reach a thickness of 5 feet but are usually thinly bedded and not persistent.

The middle member is of variable thickness but disappears before reaching the type area of the silvies Member (Localities $\mathrm{G}$ and $\mathrm{H}$ ) to the northeast. It is composed of alternating laminae of gray, green or, rarely, buff colored siltstone or sandstone and dark gray to black lutite. These alternations are usually a millimeter or so in thickness but thicken to the northeast where they may be a little in excess of one centimeter. The bleached spots that are sometimes seen have been attributed by Dickinson and Vigrass to the porphyroblastic growth of diagenetic laumonite $(1965$, p. 47). Rare, thin beds of limestone occur in the northeasterly sections but they are 
more common and thicker (up to 3 feet thick) in section 1 , to the southwest.

The Silvies Member is at a maximum thickness in the type area and thins rapidly to the southwest. It was thought that the Silvies and middle members interfingered in the headwaters of Lewis Creek (Dickinson and Vigrass, 1965, p. 49) although conglomeratic key beds were mapped as far south as Buck Creek before the Silvies Member was named (Dickinson, 1958). The interval where the Silvies Member would be expected to occur on section 5 is unfortunately covered but reconnaissance by the author and Dr. R. W. Imlay in the drainage of Rosebud Creek suggests the Member should be mappable as far south as Izee. The Silvies Member is composed of intercalations of lutites identical in lithology to the middle member and thick sequences of blue gray, hard greywacke sandstones, which weather brown, and conglomerates. The sandstone and conglomerate units may be over 100 feet (c. 30 meters) thick in the type area but the thickest individual unit seen in Section 3 is only 20 feet thick.

The upper member is the most poorly exposed. On Section 5, a thickness of 870 feet was measured but the base is not visible. The member does not reach section 1 (Big Flat) where the Trowbridge Formation rests directly on the middle member of the snowshoe Formation.

The upper member is composed of brown, green or 
black, thin-bedded mudstones and siltstones with intercalated gray, thick-bedded sandstones (which weather brown). Some parts of the section display rapid alternations of five centimeter beds of siltstone and sandstone, the latter often displaying planar cross-stratification (usually high angle). Locally, thin limestones and large, fossiliferous, calcareous nodules occur. 


\section{PALEONTOLOGY}

\section{Ammonites}

Fig. 3 shows that the Snowshoe ammonite fauna is dominated by the families Hildoceratidae, stephanoceratidae and Sonniniidae. All the other families combined constitute less than 20 percent of the fauna. The Phylloceratidae, Lytoceratidae, Oppeliidae, Hammatoceratidae, Leptosphinctinae and Macrocephalitidae are all groups represented in the Snowshoe Formation that are characteristic of the Tethyan Realm (Hallam, 1971, p. 136). In fact the Kosmoceratidae, represented by one specimen, is the only group within the Snowshoe fauna of any Boreal affinity.

A detailed statistical breakdown of the ammonite fauna to generic and subgeneric level is shown in Table I. Of the genera and subgenera listed, 17 are new to the Izee area and 7 of these are new to Oregon. The geographic distribution of the ammonites within the Izee area is summarized in Table II, which shows that most of the ammonite collections were made north of the South Fork of the John Day River. The fauna from Localities $G$ and $H$ marks the first fossils ever collected from the Silvies Member of the Snowshoe Formation.

Most of the ammonites described herein agree with the generic and subgeneric diagnoses given in the "Treatise 
PERCENT

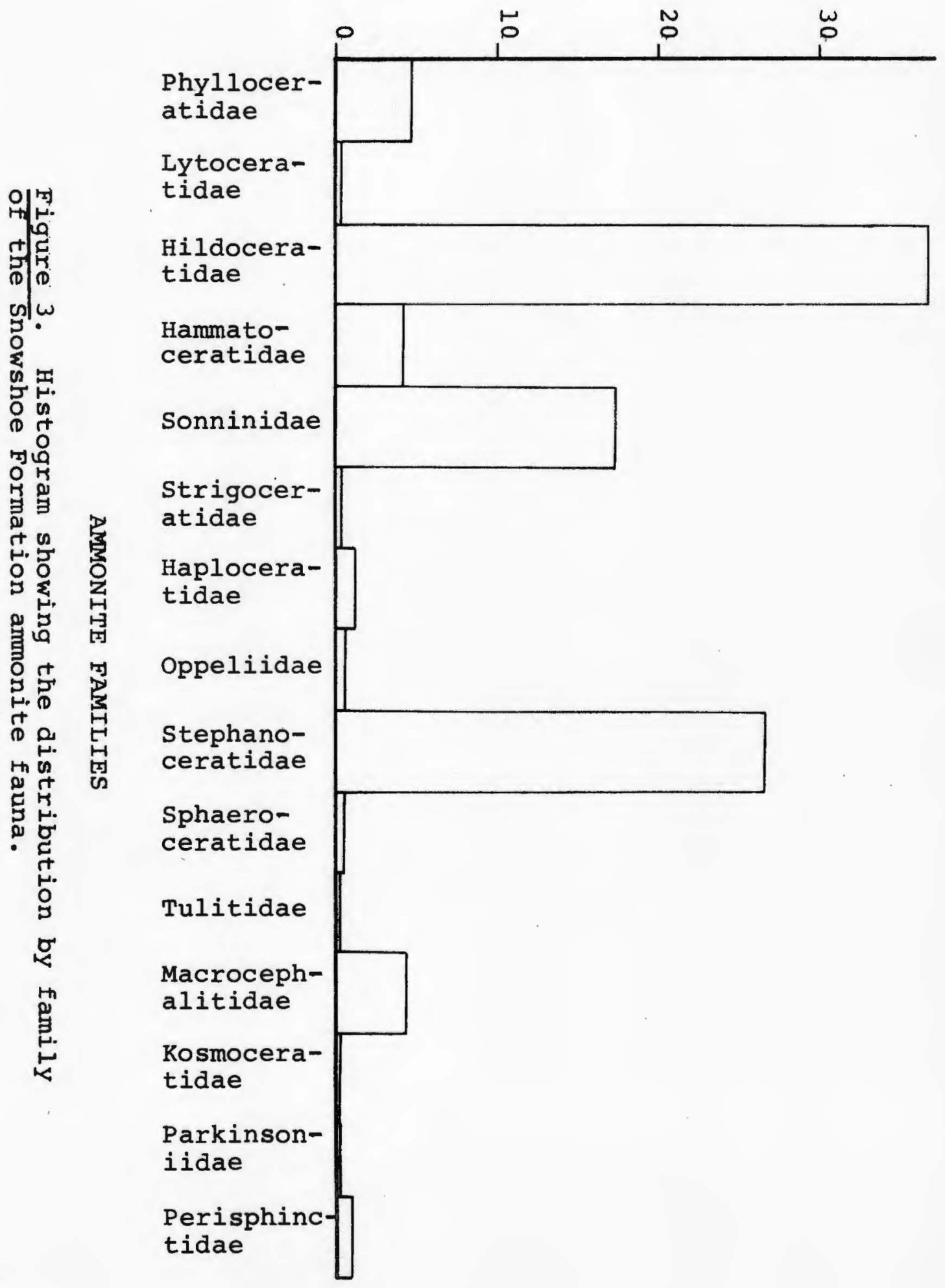


TABLE I

AMMONITE GENERA AND SUBGENERA FROM THE SNOWSHOE FORMATION SHOWING BIOLOGICAL RELATIONSHIPS AND NUMBER OF SPECIMENS AVAIIABLE FOR STUDY

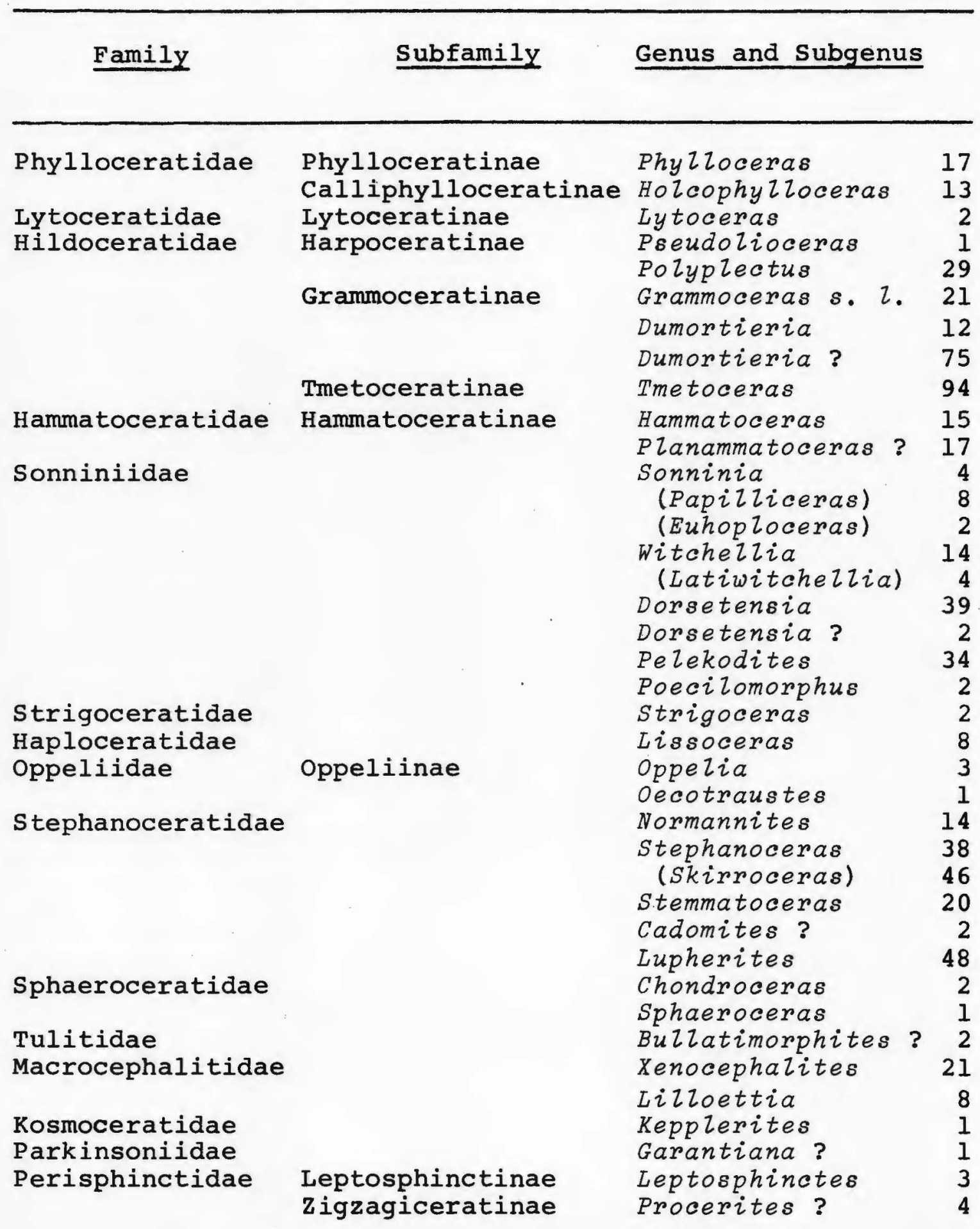


TABLE II

GEOGRAPHIC DISTRIBUTION OF THE

SNOWSHOE FORMATION FAUNA

IN THE IZEE AREA

Sections and localities are arranged from southwest to northeast (see figure 1 and Appendix A).

Key:

TAXA

Ammonite gen. and sp. indet. A

Ammonite gen. and sp. indet. B

Ammonite gen. and sp. indet. C

Aptychi

Belemnite gen. and sp. indet.

Bositra buchi (Roemer)

Bulzatimorphites ? sp.

Cadomites ? sp.

Camptonectes sp.

Chondroceras

alzani (McLearn)

Dorsetensia edouardiana (d'orbigny)

D. oregonensis Imlay
- $\quad 1$ - 2 specimens

- 3-6 specimens

- More than 6 specimens

LOC SEC SEC SEC LOC LOC SEC LOC SEC LOC $\begin{array}{llllllllll}A \& B & 2 & 1 & 4 & C & D & 5 & E \& F & 3 & G \& H\end{array}$

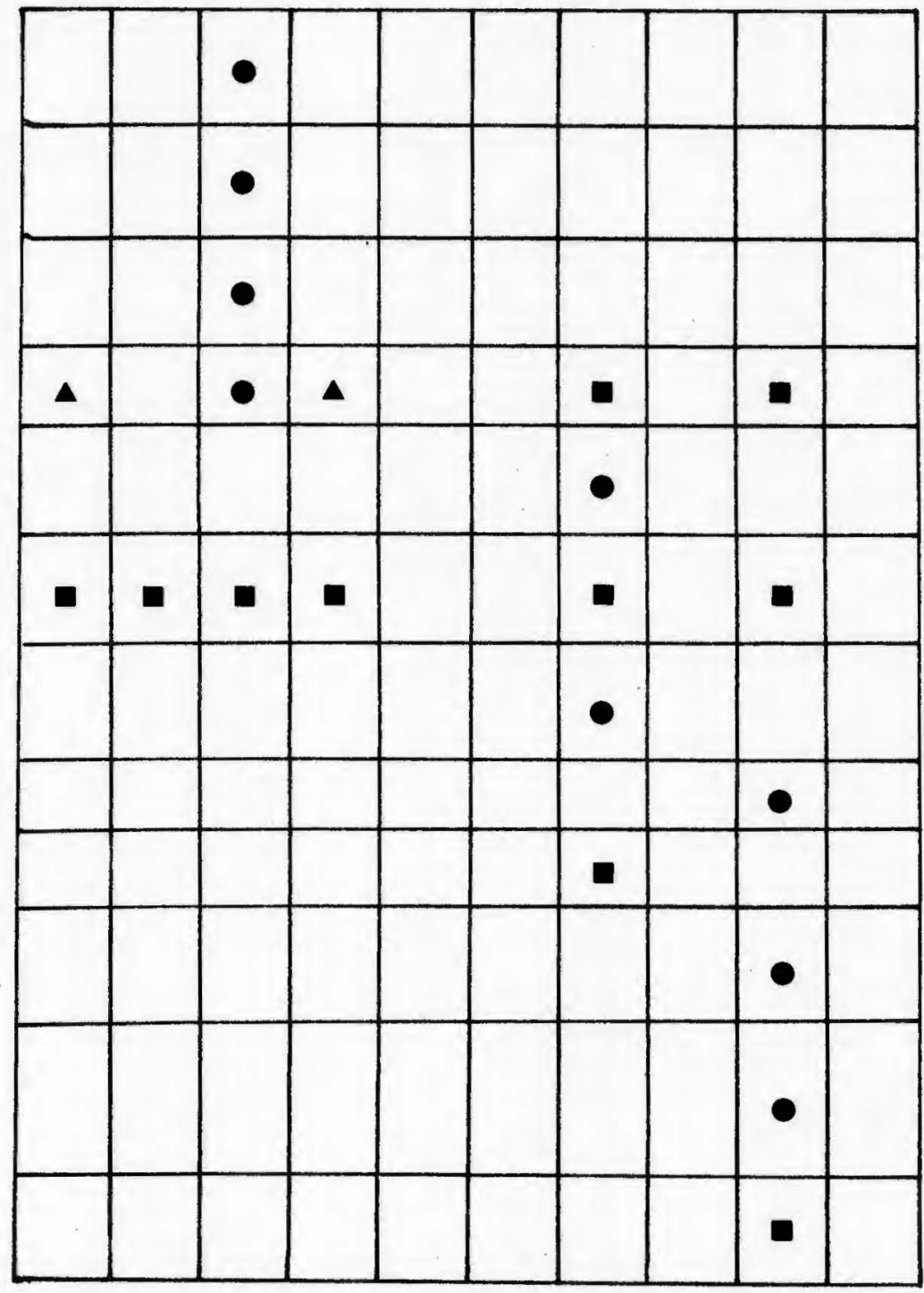


TABLE II (Continued)

TAXA

Dorsetensia pinguis (Roemer)

D. romani (Oppel)

$D$. cf. D.

subtecta Buckman

D. sp. A

D. sp. B

D. ? sp.

Dumortieria

insignisimilis (Brauns)

D. raricostata Géczy

$D$. cf. D. dumortieri

(Thiollière)

$D$. cf. $D$.

exacta Buckman

D. ? Cf. $D$.

pusizla Jaworski

Garantiana ? sp.

Gastropod gen. and sp. indet.

Grammoceras

sensu lato

Hammatoceras

speciosum

Janensch

Hammatoceras spp.
LOC SEC SEC SEC LOC LOC SEC LOC SEC LOC $\begin{array}{llllllllll}A \& B & 2 & 1 & 4 & C & D & 5 & E \& F & 3 & G \& H\end{array}$

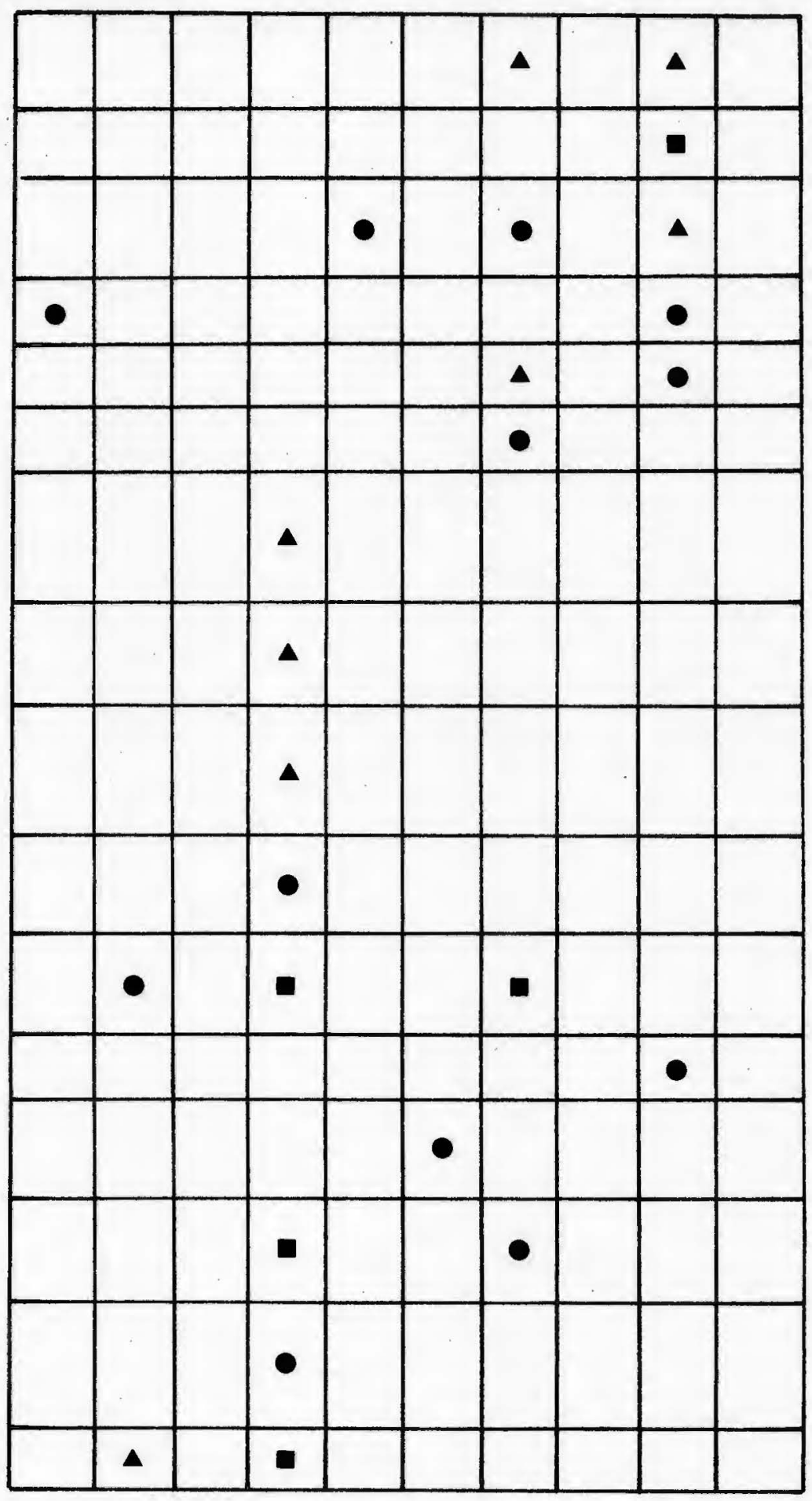


TABLE II (Continued)

TAXA

Holcophylzoceras costisparsum Imlay

Kepplerites spinosum (Imlay)

Leptosphinctes cf. L. evolutus Imlay

$L$. $\mathbf{s p}$.

Lilloettia

buckmani

(Crickmay)

L. Zizloettensis Crickmay

L. mertonyarwoodi

? Crickmay

L. mizleri?

Imlay

Lissoceras hydei Imlay

Lupherites

senecaensis Imlay

Lytoceras

espinazitum Pugin

$L$. aff. $L$.

eudesianum

(d'Orbigny)

Normannites (N.) orbignyi (Buckman)

N. cf. N. vigorosus (Imlay)

N. sp.
LOC SEC SEC SEC LOC LOC SEC LOC SEC LOC

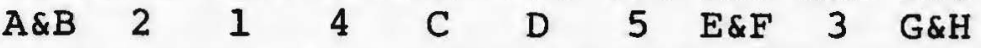

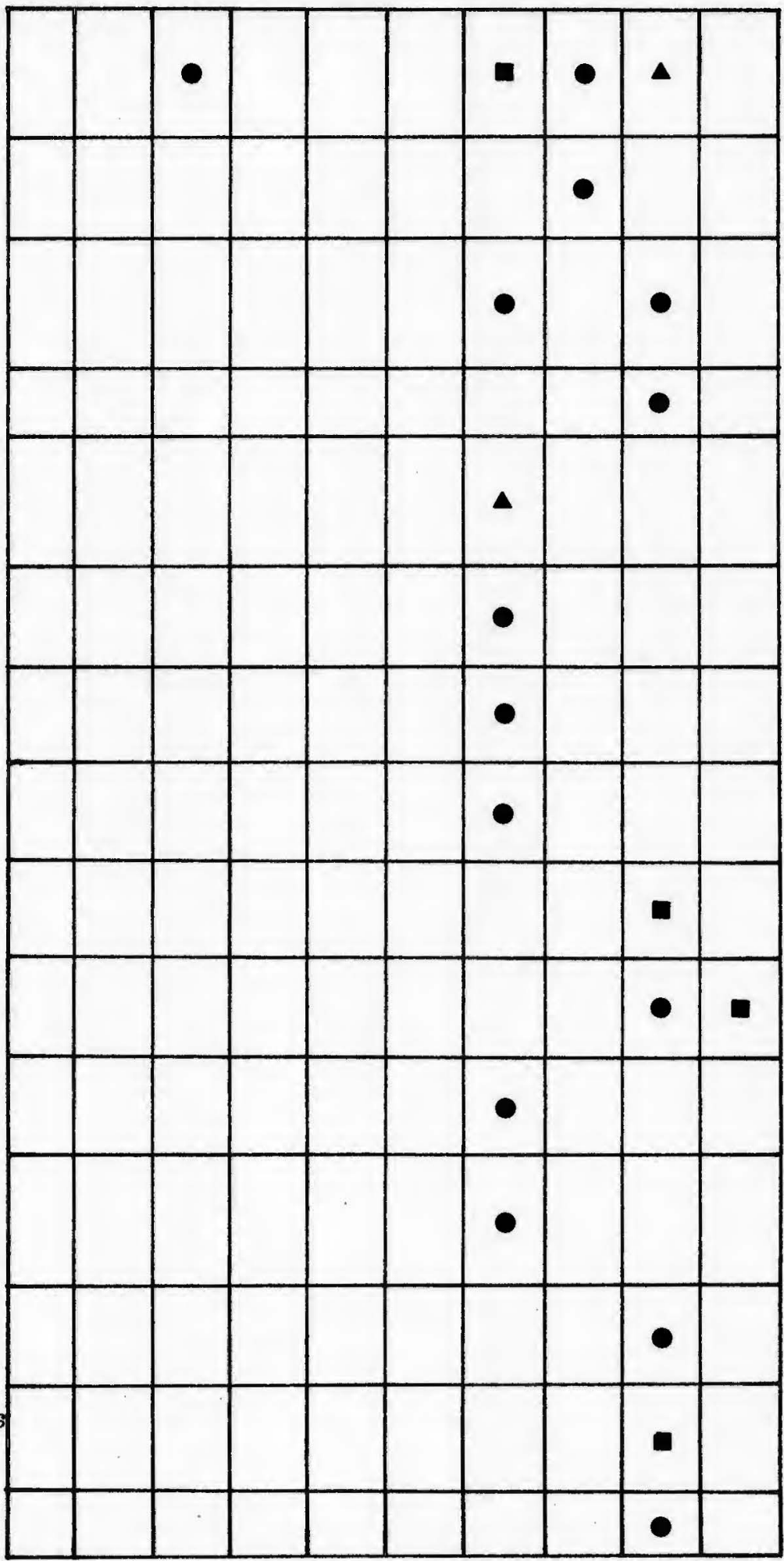


TABLE II (Continued)

TAXA

LOC SEC SEC SEC LOC LOC SEC LOC SEC LOC

oecotraustes sp.

Oppelia subradiata ? (J. de C.

Sowerby)

Oysters

Pelekodites

silviesensis Imlay

P. dobsonensis

Imlay

P. cf. $P$.

zurcheri

(Douvillé)

P. spp.

PhyZloceras kunthi

? Neumayr

P. sp.

Planammatoceras

? spp.

Poecizomorphus

varius Imlay

Polyplectus spp.?

Procerites ? sp.

Pseudolioceras cf. spitsbergense Frebold

Sonninia cf. S. nodatipinguis

(Buckman)

S. sp.

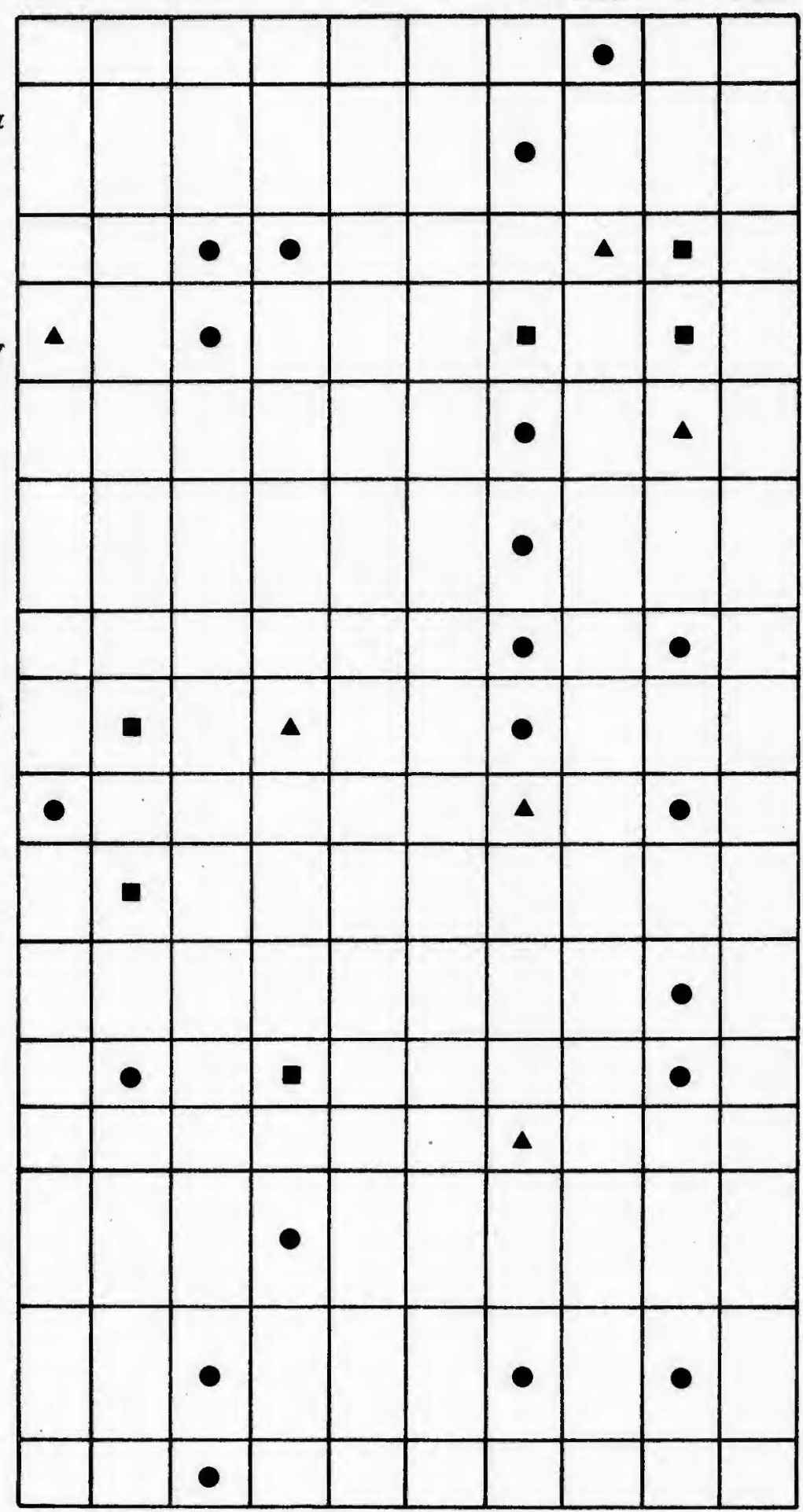


TABLE II (Continued)

$\begin{array}{llccccccccc} & \text { LOC } & \text { SEC } & \text { SEC } & \text { SEC } & \text { LOC } & \text { LOC } & \text { SEC } & \text { LOC } & \text { SEC } & \text { LOC } \\ \text { TAXA } & \text { A\&B } & 2 & 1 & 4 & \text { C } & \text { D } & 5 & \text { E\&F } & 3 & \text { G\&H }\end{array}$

Sonninia

(Euhop Zoceras) spp.

S. (Papilizeras)

spp.

Sphaeroceras sp.

Stemmatoceras aff.

S. albertense

McLearn

S. sp.

stephanoceras nodosum

(Quenstedt)

S. sp. A

S. spp.

S. n. sp.?

S. (skirroceras)

juhlei Imlay

S. (S.) kirschneri Imlay

S. (S.) aff.

S. (S.) juhlei

Imlay

Strigoceras cf. S. Zanguidum

(Buckman)

Tmetoceras scissum (Benecke)

Witchellia connata (Buckman)

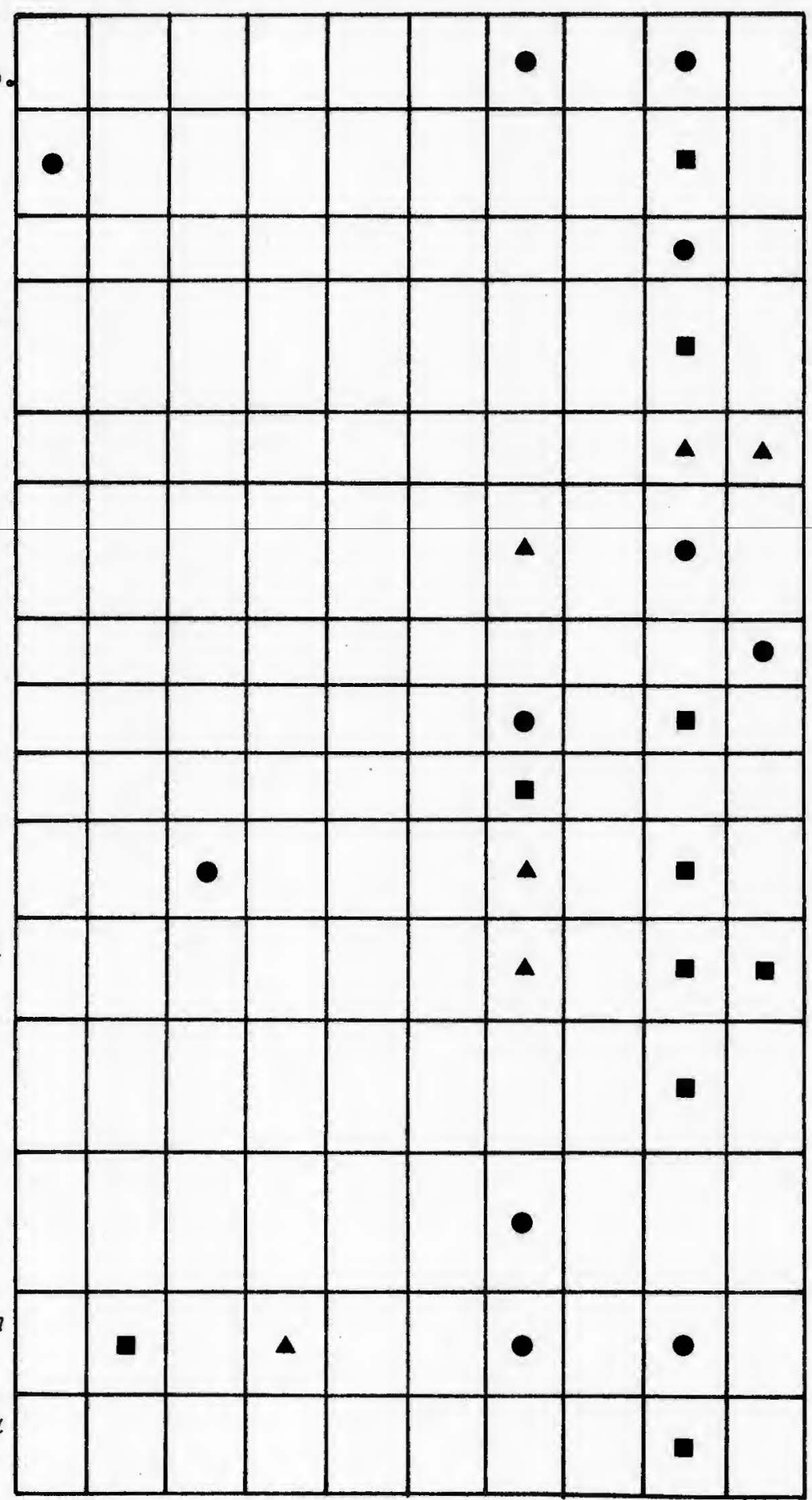


TABLE II (Continued)

\begin{tabular}{|c|c|c|c|c|c|c|c|c|c|c|}
\hline TAXA & $\begin{array}{l}\text { LOC } \\
\mathrm{A} \& \mathrm{~B}\end{array}$ & $\begin{array}{c}\text { SEC } \\
2\end{array}$ & $\begin{array}{c}\text { SEC } \\
1\end{array}$ & $\begin{array}{c}\mathrm{SEC} \\
4\end{array}$ & $\begin{array}{l}\text { LOC } \\
\text { C }\end{array}$ & $\begin{array}{c}\text { LOC } \\
\text { D }\end{array}$ & $\begin{array}{c}\text { SEC } \\
5\end{array}$ & $\begin{array}{l}\text { LOC } \\
\mathrm{E} \& \mathrm{~F}\end{array}$ & $\begin{array}{c}\text { SEC } \\
3\end{array}$ & $\begin{array}{l}\text { LOC } \\
\text { G\&H }\end{array}$ \\
\hline Witchellia spp. & - & & $\bullet$ & & & & & & & \\
\hline $\begin{array}{l}\text { W. (Latiwitchellia) } \\
\text { evoluta Imlay }\end{array}$ & & & & & & & & & $\Delta$ & \\
\hline Wood & & $\bullet$ & $\bullet$ & & & & 0 & & $\Delta$ & - \\
\hline $\begin{array}{l}\text { Xenocephalites } \\
\text { vicarius Imlay }\end{array}$ & & & & & & & 口 & & & \\
\hline
\end{tabular}


on Invertebrate Paleontology" (Arkell, et al., 1957). Genera listed in the "Treatise" and regarded here as synonomous are discussed in detail below. In addition, those taxa are discussed which have proved difficult to work with due to controversy over their status. The bearing of the hypothesis concerning sexual dimorphism in ammonites, that has been generally accepted since the "Treatise" was written, is outlined in terms of its effect on nomenclature.

Dumortieria, Catulloceras and Tmetoceras were recognized as distinct genera within the family Hildoceratidae by Arkell (1957, p. L262) although Tmetoceras was placed in a separate, monotypic, sub-family (after Spath, 1936, p. 3). Dumortieria and Catulzoceras are restricted to the upper Toarcian whereas Tmetoceras is thought to be restricted to the lower Bajocian. Recent developments in the literature have cast doubts on the validity of these genera and, although a major taxonomic revision is well beyond the scope of this work and the capacity of the hypodigm available, a discussion of the approach adopted herein should prove useful.

The relationship between CatulZoceras and Tmetoceras is interesting. The former is similar in appearance to the latter except that CatuZZoceras possesses a low keel whereas on the ventral surface of Tmetoceras, a sulcus bordered by the swollen ventral ends of the ribs is evident. 
Constrictions are common to both, to a greater or lesser extent, but Westermann (1964a, p. 432) has demonstrated with Tmetoceras that no great taxonomic significance can be attached to their presence or absence since the segmental growth which they represent was probably environmentally controlled. Tmetoceras probably evolved from Catulzoceras by the gradual change in features of the ventral surface, a lineage suggested by many workers $(e . g$. Roman, 1938, p. 100) and, as such, the wisdom of placing them in separate subfamilies is open to question. The stratigraphic evidence also indicates the intimate connection between the two genera. Catulzoceras ranges through the Moorei and Aalensis sub-zones of the Levesquei zone (uppermost Toarcian) in the northwest European province (see fig. 5). Tmetoceras has been recorded throughout the Opalinum, Scissum and Murchisonae Zones of the lowermost Bajocian (Westermann and Riccardi, 1972, p. 22). However, it has also been reported from the uppermost Toarcian by Donovan (1958, p. 40, p. 53) and Westermann (1964a, p. 433). Thus the uppermost portion of the range of Catuzzoceras possibly overlaps the lower part of the range of Tmetoceras. Furthermore, a complete morphological intergradation has been observed between the two genera over a short stratigraphic interval (Westermann, 1964a, p. 433). Concentrating on the two Toarcian genera, we find that the situation is not quite so straightforward. 
Dumortieria is a genus showing a considerable range in the strength and nature of the ribbing. Low in the Levesquei Zone there occurs what Ernst has referred to as the "Levesquei-Gruppe" (1923, p. 118) which consists of coarsely ribbed species that are later almost entirely replaced by the finely ribbed "Radiosa-Gruppe". The morphological variability displayed by Dumortieria has also been discussed in considerable detail by Setti (1968). Dumortieria is distinguished from Catuzzoceras by its slightly lower keel; ribs that flex more prorsiradiately onto the venter and (supposedly) by the absence of constrictions (Imlay, 1968, p. C4). These minor differences have not been considered valid by some workers and as a consequence, CatuZZoceras and Dumortieria have been regarded as synonomous (Donovan, 1958, p. 53; Géczy, 1967, p. 137; Setti, 1968, p. 320). Recent objections to this practice have been raised by Guex (1975) who feels that he has established distinctly different stratigraphic ranges for the two genera in the Causses, France. However, after close examination of what after all are only the teilzones that he presents, it can be seen that rather than increasing the range of Catuzzoceras below that of Dumortieria (Guex, 1975, p. 124), he merely extends the range of Catuzzoceras to include the Reynesi sub-zone of the Insigne Zone so that the new range coincides with that established for Dumortieria in northwest Europe (Dean, Donovan and Howarth, 
1961, p. 489). This is summarized in fig. 4.
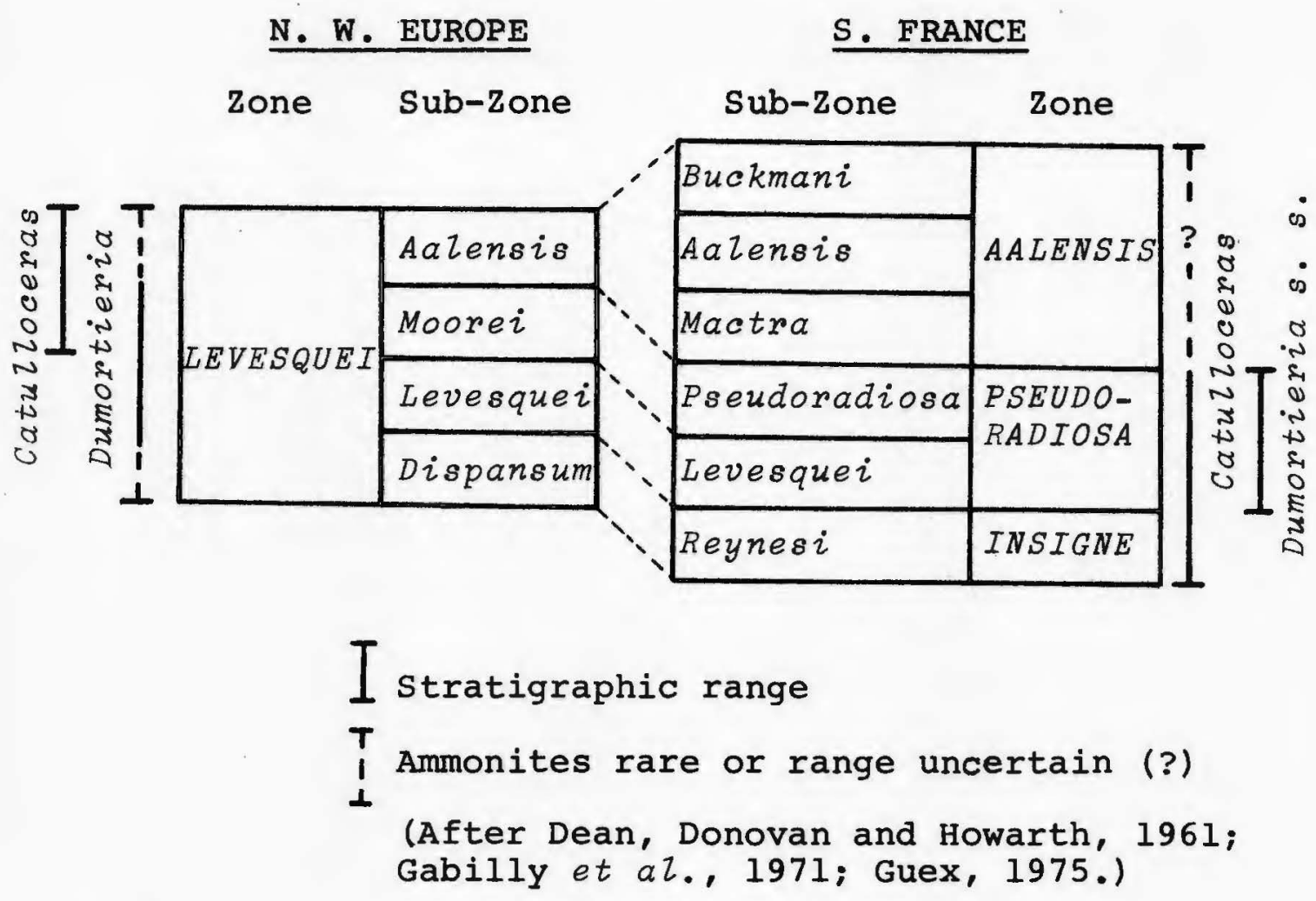

Figure 4. The stratigraphic range of Dumortieria Haug and Catuzzoceras Gemmellaro in northwest Europe and southern France.

Specimens collected during this study are generally poorly preserved with the ventral surface often difficult to see. Tmetoceras is readily distinguished by the swollen ventral ends of the ribs that protrude beyond the outline of the shell, especially when the shell is flattened. The genus is further characterized by its rectiradiate costation. Catuzloceras is here regarded as a synonym of Dumortieria for the reasons stated above. Minor differences such as differing keel heights and relative magnitude of 
ventral rib inflection could only be satisfactorily determined using a large, well preserved population sample. The genus Dumortieria can therefore be differentiated from Tmetoceras on the basis of the ribbing which flexes prorsiradiately onto the ventral surface in Dumortieria, and by the presence of a keel as opposed to a ventral sulcus (or smooth band). The family Sonniniidae contains a diverse suite of ammonites whose sutures tend to show a trifid first lateral lobe where the three accessory lobes are approximately of equal length, no matter how complex. The family ranges from the Concavum zone (Bajocian) to the Lower Bathonian with the acme in the Middle Bajocian. Several sonniniid genera are represented in east-central oregon but the taxonomy of the group is by no means straightforward, genera often having been retained simply because they are stratigraphically useful.

Sonninia sensu stricto comprises planulate forms characterized by fairly evolute coiling with moderately compressed whorls; a narrow venter bearing a high, hollow keel; lateral tubercles or swellings on inner and intermediate sized whorls; strong, irregular, flexuous to sickle-shaped ribs that may divide into two or more secondary ribs, and a more or less smooth body chamber (Imlay, 1973, p. 4). Sonninia s. $s$. is only questionably represented in the Izee area but poorly preserved specimens of its two subgenera Papilliceras and Euhoploceras, have been collected. The 
subqenus, Papilliceras, contrasts with Sonninias. s. in being more evolute and more compressed and in having simpler, straighter, more uniform ribs that are rectiradiate on the lower parts of the flanks and curve slightly forward on the upper parts. Strigation may be present and most characteristically, a median row of lateral tubercles occurs on the septate whorls and on some body chambers (Imlay, 1975, p. 5). Euhoploceras is an extremely variable group and has been the subject of intensive study. The many species of Euhoploceras that were first named by Buckman from the exceedingly fossiliferous Discites Zone at Bradford Abbas, England were later included in a single species, Sonninia adicra (Waagen) by Westermann (1966). Westermann, using semi-quantitative work, maintained that all Buckman's species were morphological variants and that, if necessary, infrasubspecific categories ( $v i z$. "forma") should be recognized within S. adicra (Westermann, 1966, p. 310). Westermann's arguments were based on the premise that the Bradford Abbas deposits were not condensed and that the ammonites found together, actually lived together. Unfortunately, this does not seem to be the case (Morton, 1975, p. 46) and Euhoploceras must, for the time being, be recognized as distinct. It can be differentiated from Sonninia by its broader, more quadrate whorls; distinct subtabulate (or even bisulcate) venter, and low keel (Morton, 1975, p. 44).

The many similarities between the sonniniid genera 
Witchellia and Dorsetensia have led some workers to regard the latter as a junior synonym (see Morton, 1972, p. 505) whereas Oechsle (1958, p. 77 and passim) went a step further and included both genera in Sonninia. Dorsetensia was recently restudied and revised by Huf (1968). It consists of forms ranging from small and evolute with a shallow umbilicus, low solid keel, and sharp ribbing to large and involute with a deep umbilicus, pronounced hollow keel, and absence of ribbing (the "liostraca group" of Buckman, 1892, p. 308; see also the generic diagnosis of Huf, 1968, p. 72). The umbilical wall is vertical and the shoulder abruptly rounded. Ribs or lirae are falcoid and simple except on the innermost whorls (Imlay, 1973, p. 7; cf. discussion of D. pinguis below). The whorl section is ovate (higher than wide) to triangular and ornamentation in the form of nodes is distinctly absent. A group of ammonites classed here with Dorsetensia has had a varied and colorful history. They are characterized by being evolute and strongly ribbed, except that the ribbing branches near the umbilical edge and the venter may be bisulcate and as such they resemble Witchellia (see below). Dorsetensia pinguis and $D$. hannoverana are typical examples. These species have been included in Sonninia by Hiltermann (1939, p. 164-170) and Oechsle (1958, p. 113); in Witchellia by Dorn (1935, p. 116) and in Poecizomorphus by Huf (1968, p. 54-69). It was Huf (1968, p. 54) who first noticed the occurrence of intermediates 
between $D$. hannoverana and $D$. deltafalcata (Quenstedt). Morton (1972, p. 505) finally transferred them to Dorsetensia and it is this practice that is followed here.

The lectotype of the genus Witchellia (w. Zaeviuscula (J. de C. Sowerby)) has been refigured by Westermann (1969b, text-fig. 35). Witchellia is characterized by its compressed whorls; involute to fairly evolute coiling; a distinctly separate venter bearing a low keel bordered by furrows; weak to fairly strong, flexuous ribs that arise singly and in pairs at the base of the flanks, trend radially or slightly forward on the flanks and may weaken or fade out on the body chamber; and tubercles on the smallest septate whorls (Imlay, 1973, p. 5). The subgenus Latiwitchellia also has a bisulcate, carinate venter and some rib furcation at the base of the flanks but the coiling is much more evolute, the whorls stouter, the ribbing stronger on the body chamber and there may be blunt nodes high on the flanks (Imlay, 1973, p. 6).

The genus Pelekodites is a loose group composed of polyphyletic microconchs. The species are small and evolute with low umbilical walls. A low, blunt keel is bordered by narrow, smooth areas; the ribbing is simple rursiradiate to biconcave, becoming stronger ventrally and adorally. When preserved, the aperture bears lateral lappets. This genus might well become obsolete as sexual pairings are made, perhaps with Sonninia or Witchellia (Morton, 1975, 
p. 45; see discussion of sexual dimorphism in this report,

p. 30 .

Sonninias. s. ranges from the upper Concavum zone to the lower Humphriesianum Zone (Imlay, 1973, p. 19; Morton, 1975, passim). EuhopZoceras is restricted to the Discites Zone (Westermann, 1966, p. 19) but has been reported from the upper Concavum Zone (Morton, 1975, passim) and also associated in the upper part of its range with Papizliceras in Oregon (? Laeviuscula Zone) (Imlay, 1973, p. 5). This association is not corroborated by the detailed studies of Taylor (1976). Papizziceras itself is restricted to the Sauzei Zone (Westermann and Riccardi, 1972, p. 75; Morton, 1975, p. 76, 78) except for the association with Euhoploceras mentioned above. According to most authors, Witchellia is restricted to the Laeviusoula zone and this is one of the main arguments for retaining Dorsetensia, which is mainly restricted to the Humphriesianum zone (Morton, 1972, p. 505). However, Witchellia has been reported from the Sauzei Zone (Imlay, 1973, p. 19) as has Dorsetensia (Dorn, 1935, p. 120; Imlay, 1973, p. 7). The Dorsetensia pinguis group is characteristic of the upper Sauzei and lower Humphriesianum Zones (Morton, 1972, p. $505 ; 1976$, p. $28,29,31)$. The subgenus of Witchezzia, Latiwitchellia, was previously found to occur only in the Discites zone (lower "Sowerbyi zone", Imlay, 1973, p. 7) and was therefore older than the oldest occurrences of 
Witchellia in Europe. This restricted range is not substantiated here since the subgenus is found associated with Witchellia and Dorsetensia on Section 3 (see fig. 8). Pelekodites ranges from the Discites zone to the Sauzei Zone inclusive.

In 1963 two classic papers were published simultaneously and independently concerning the recognition of sexual dimorphism in Jurassic ammonites (Callomon, 1963; Makowski, 1963). The association of forms that were identical in all respects except for shell size and the nature of the peristome had been noticed before but these were the first attempts to draw together the facts and offer an acceptable explanation. The larger macroconchs, as they have been called, possess a simple collared peristome whereas the smaller microconchs possess various forms of lateral lappets. Parallel lineages evident in both types have allowed the hypothesis of sexual dimorphism to be well established.

Sexual dimorphism is a subject that has regenerated the old controversy of the species problem in paleontology. The topic of the morphospecies and the biospecies has received much attention from paleontologists and neontologists alike (see, for example,sylvester-Bradley, 1956) but the main problem here is one of nomenclature. Forms that are now recognized as sexual dimorphs have been accorded separate specific and even generic rank in the past. The 
Rules of Zoological Nomenclature hold that sexual dimorphs should bear the same specific name and recommends that the law of priority apply (Stoll, 1961, Article 24 (b), p. 27). However, since sexual dimorphism in ammonites can only remain a hypothesis, the issue cannot be forced by the Rules of Nomenclature. As a consequence, two different nomenclatural approaches are evolving at present, one where the dimorphs are accorded subgeneric rank and the other where the dimorphs are given the same name and differentiated using the standard biologic symbols for male and female. This whole problem of dimorphism and its effect on nomenclature was thought to be so important as to be worthy of an international symposium almost held in Prague (Westermann, Ed., 1969a).

Certain Toarcian and Bajocian ammonites collected during this study show evidence of sexual dimorphism but the pairing up of dimorphs and "marriage" into a single species would be foolhardy at this early stage. More stratigraphically controlled collecting in surrounding areas is necessary so that paleoecological factors can be taken into account, and precise stratigraphic ranges can be compared. Features of sexual dimorphism will be described and discussed but standard binomial names will be applied. This conservative approach, with the aim of encouraging nomenclatural stability, has been adopted by several workers where pairings are obscure le.g. Morton, 
1975) or where detailed biostratigraphic studies are just beginning (Imlay, 1973).

At a higher taxonomic level, however, it becomes impossible to recognize the family Otoitidae (Arkell, et a ., 1957, p. L287) which is composed predominantly of microconchs now paired with members of the stephanoceratidae and Sphaeroceratidae. The abandonment of Arkell's classification on this point, which in the case of the snowshoe Formation fauna concerns only Normannites, is based on arguments and discussions presented by Westermann (1954, 1964b), Imlay (1964b) and Morton (1971b).

\section{Other Fossils}

One very interesting aspect of the snowshoe fauna is the abundance of ammonite aptychi which are usually rare except in rocks of the "Posidonia" Facies (see section of paleoecology, p. 54). All the specimens collected are true aptychi consisting of paired calcareous structures as opposed to the single unmineralized objects often referred to as anaptychi (Kennedy and Cobban, 1976, p. 12). Aptychi are often found in the body chambers of ammonites or, rarely, closing off the aperture. Basically, there are two theories as to the function of aptychi. One school of thought maintains that aptychi were opercula that could be withdrawn to a ventral resting position (Arkell, et al. 1957, p. L99) or perhaps lifted dorsally as with modern Nautilus (Schindewolf, 1958, p. 1). The other, more current 
school maintains that anaptychi and probably aptychi functioned as jaws (Lehmann, 1970, 1971, 1972) although Kennedy and Cobban have suggested that aptychi underwent a secondary adaptation to function as opercula (1976, p. 13). No attempt has been made as yet to split the snowshoe aptychi into the taxonomic units described in the "Treatise" which this author feels to be inadequate. Most of the aptychi were found completely isolated while others were found next to, but not inside, the body chambers of ammonites whose apertural size would have corresponded approximately to the size of the aptychi. Some of the aptychi compare with those found in the body chambers of sonniniids collected from Scotland (Morton, 1973). Others show a diversity of size, shape, ornamentation and stratigraphic range suggesting that several genera are represented. The aptychi from the Snowshoe Formation will be the subject of a detailed study at a later date.

Other fossils that were collected from the snowshoe Formation include a variety of pelecypods such as ostrea, Gryphaea? (grouped as "oysters"), Inoceramus ? and Camptonectes (pl. 9, fig. 12). By far the most abundant is the small Bositra buchi (Roemer) (Rosidonomya alpina and Posidonia ornati, auct.) which crowds bedding planes at many horizons throughout the sequence, but most commonly in the lower member.

While carrying out thin-section studies, Dickinson 
came across minute "ovoid, bell-shaped and helmet-shaped" objects in the mudstones of the lower, middle and silvies members that he took to be replaced or recrystallized radiolarian tests $(1965$, p. 46). These objects comprise 10 to 25 percent of the mudstones. Samples of the limestones collected from the lower member on section 3 were dissolved in acid to reveal perfectly preserved radiolaria, with spines intact, indicating that Dickinson's inferences were correct.

Much of the dark color of the mudstones in the lower member is attributed to dispersed organic matter. Black and brown organic material is often visible on bedding planes. Some of this material may be the remains of radulae and perhaps siphuncles (see Andalib, 1972) although most is probably attributable to fish. On a larger scale, pieces of carbonized wood up to 15 centimeters in length have been collected from rare localities in all the members of the Snowshoe Formation.

Two specimens of turreted gastropods were collected from beds of Silvies-like lithology behind the Izee Schoolhouse (pl. 9, fig. 9). One small, poorly preserved belemnite was found 840 feet (256 meters) above the base on Section 5 where a few rhynchonellid brachiopods were also collected from a nodule 50 feet (c. 15 meters) above the base. 


\section{BIOSTRATIGRAPHY}

The stages and standard zonal succession used in this work are shown in $\mathrm{fig.} \mathrm{5.} \mathrm{The} \mathrm{Callovian} \mathrm{stage} \mathrm{is}$ assigned to the Upper Jurassic in accordance with the current practice of the United States Geological Survey. It should be noted, however, that many workers now regard this stage as part of the Middle Jurassic because such a designation has historical priority (von Buch, 1837, p. 49; Arkell, 1956, p. 8; Hallam, 1975, table 2.1). The term Aalenian is here regarded as a synonym of the lower Bajocian following the recommendations of the Luxembourg colloquia on the Jurassic System (Sapunov, 1964, p. 226; Morton, 1971a, p. 86). The zonal scheme incorporates several revisions over that used by Arkell (1933, 1956, 1957) to include the work of Dean, Donovan and Howarth (1961) and the more recent work of Parsons (1974). The stages and zones recognizable in each section have been marked on the stratigraphic columns where the ranges of each taxon are also indicated (figs. 6 to 11). The correlation between sections and some localities within the Izee area is shown in fig. 12 (cf. fig. 2). The significance of these correlations is discussed in the concluding part of the section on biostratigraphy. 


\begin{tabular}{|c|c|c|c|}
\hline SYSTEM & \multicolumn{2}{|c|}{ STAGE } & ZONE \\
\hline $\begin{array}{l}\text { UPPER } \\
\text { JURASSIC }\end{array}$ & CALLOVIAN & LOWER & $\begin{array}{l}\text { Sigaloceras calloviense } \\
\text { Macrocephalites macrocephalus }\end{array}$ \\
\hline \multirow{6}{*}{$\begin{array}{l}\text { MIDDLE } \\
\text { JURASSIC }\end{array}$} & \multirow{3}{*}{ BATHONIAN } & Upper & $\begin{array}{l}\text { Clydoniceras discus } \\
\text { oppelia aspidoides }\end{array}$ \\
\hline & & Middle & $\begin{array}{l}\text { Tulites subcontractus } \\
\text { Procerites progracilis }\end{array}$ \\
\hline & & Lower & Zigzagiceras zigzag \\
\hline & \multirow{3}{*}{ BAJOCIAN } & Upper & $\begin{array}{l}\text { Parkinsonia parkinsoni } \\
\text { Garantiana garantiana } \\
\text { Strenoceras subfurcatum }\end{array}$ \\
\hline & & Middle & $\begin{array}{l}\text { Stephanoceras humphriesianum } \\
\text { otoites sauzei } \\
\text { Witchellia Zaeviuscula } \\
\text { Hyperlioceras discites }\end{array}$ \\
\hline & & Lower & $\begin{array}{l}\text { Graphoceras concavum } \\
\text { Ludwigia murchisonae } \\
\text { Tmetoceras scissum } \\
\text { Leioceras opalinum }\end{array}$ \\
\hline $\begin{array}{l}\text { LOWER } \\
\text { JURASSIC }\end{array}$ & TOARCIAN & Upper & $\begin{array}{l}\text { Dumortieria levesquei } \\
\text { Grammoceras thouarsense } \\
\text { Haugia variabilis }\end{array}$ \\
\hline
\end{tabular}

(After the works of Arkell (see text); Dean, Donovan and Howarth, 1961; Parsons, 1974; Cox, 1964; Callomon, 1964; and others.)

Figure 5. Standard zones of the European Jurassic. 
Key: For figures 6 to 11 (stratigraphic columns). Figures 8 and 10 are found in the pocket.

Abundance symbols: (for intervals of ten stratigraphic feet).

- 1 - 2 specimens

$\Delta \quad 3$ - 6 specimens

- More than 6 specimens

I Approximate generic range

Abbreviations:

U.

Upper

M.

L.

Loc.

H.

$\operatorname{Tr}$.

Ro.

$\mathrm{Baj}$.

Toarc.

Humph.

Middle

Lower

Locality

Hyde

Laev.

Murch.

Trowbridge

Rosebud

Bajocian

Toarcian

Humphriesianum

Laeviuscula

Levesqu. Levesquei
Iithologic symbols:

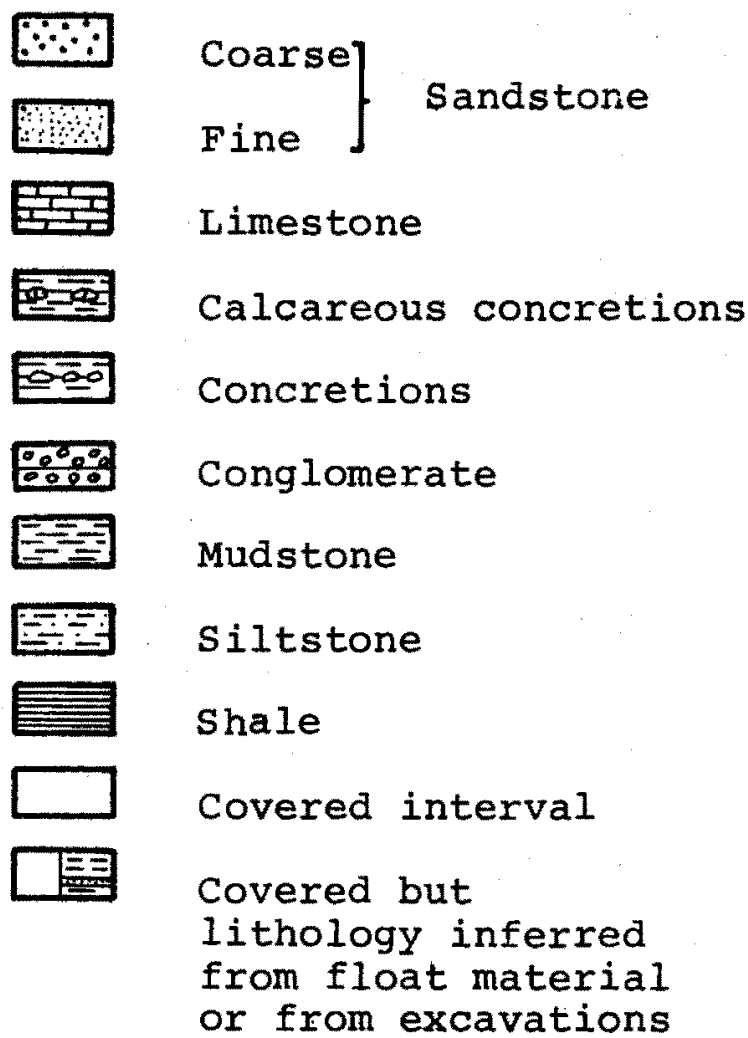




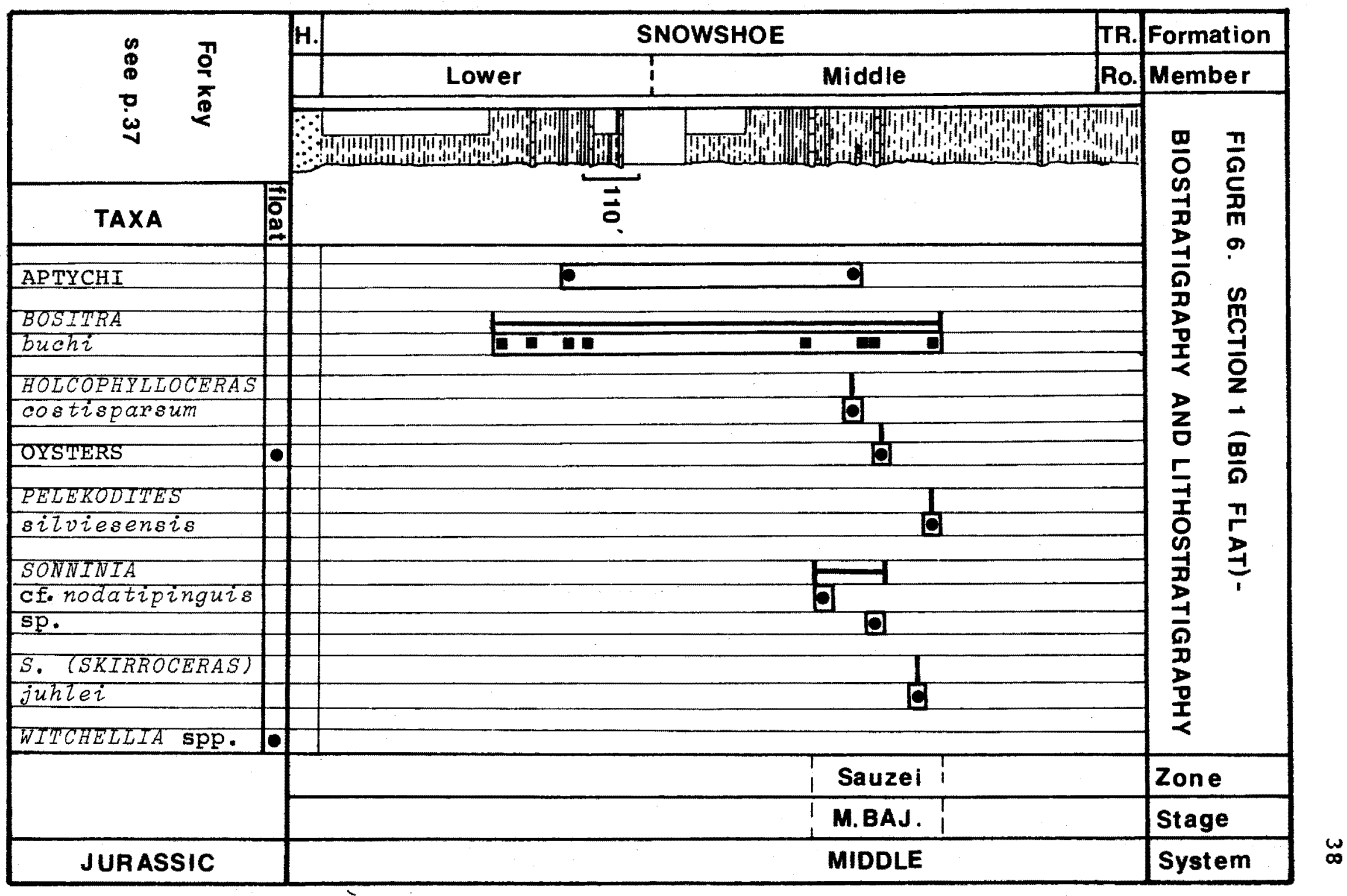




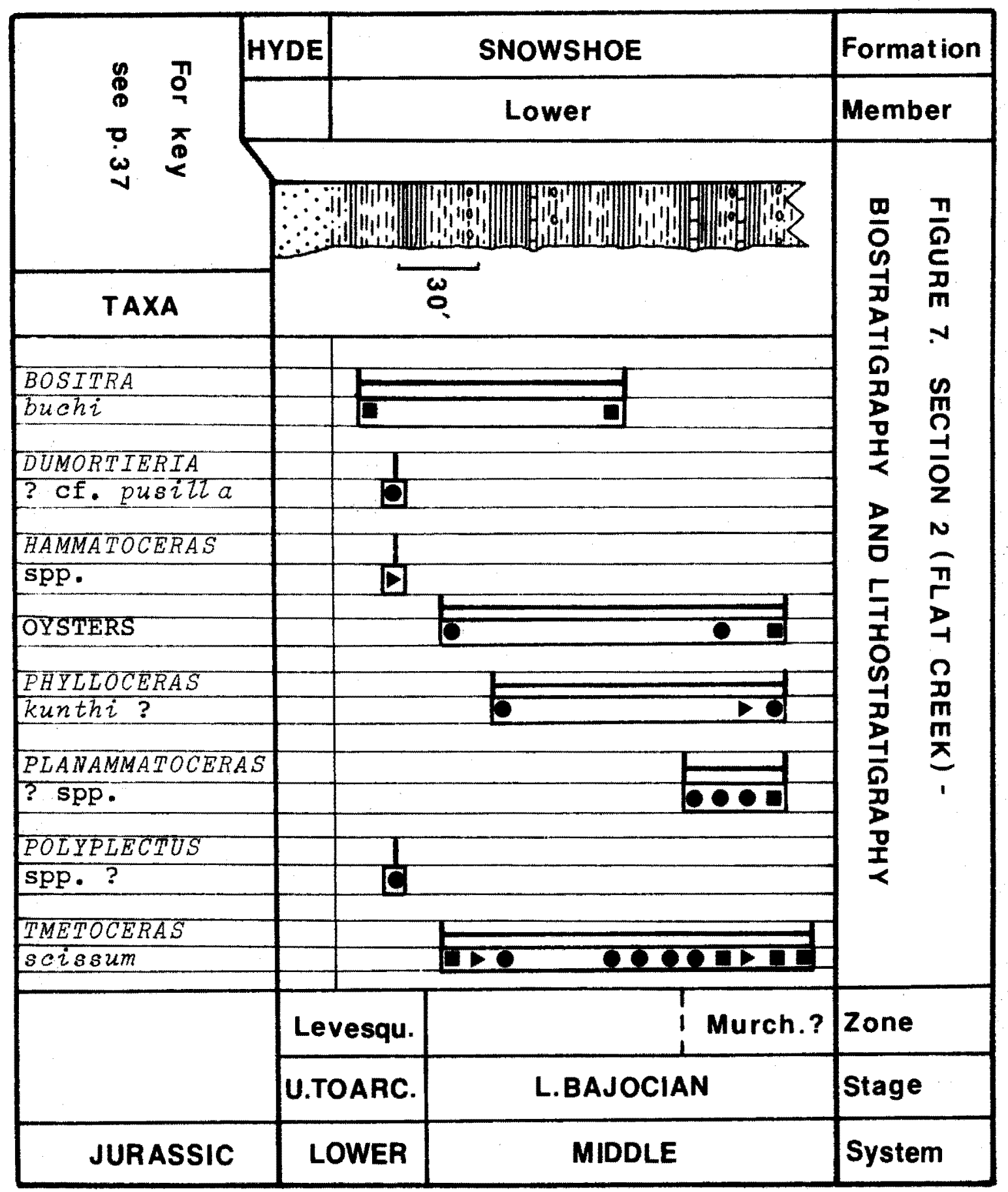




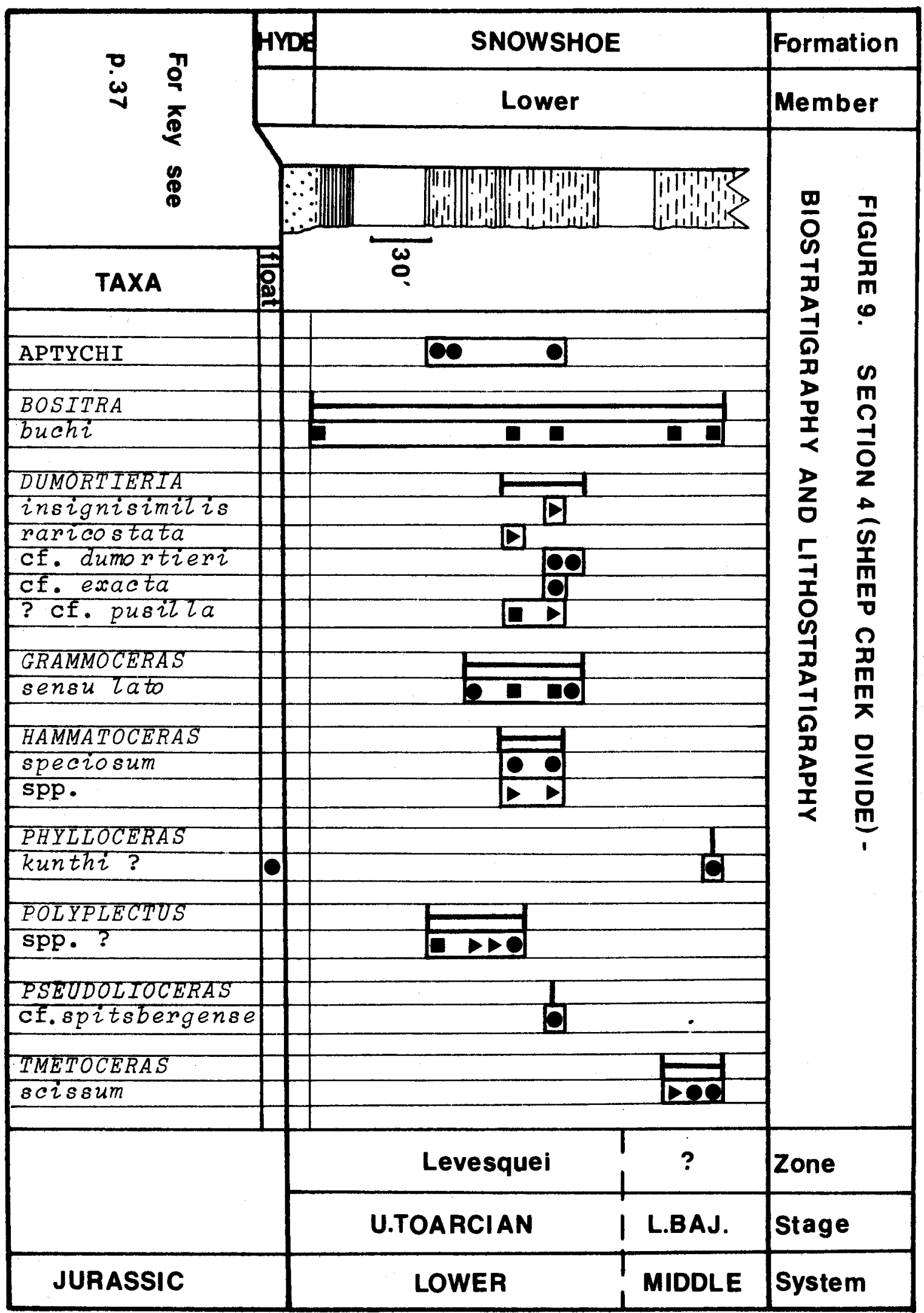




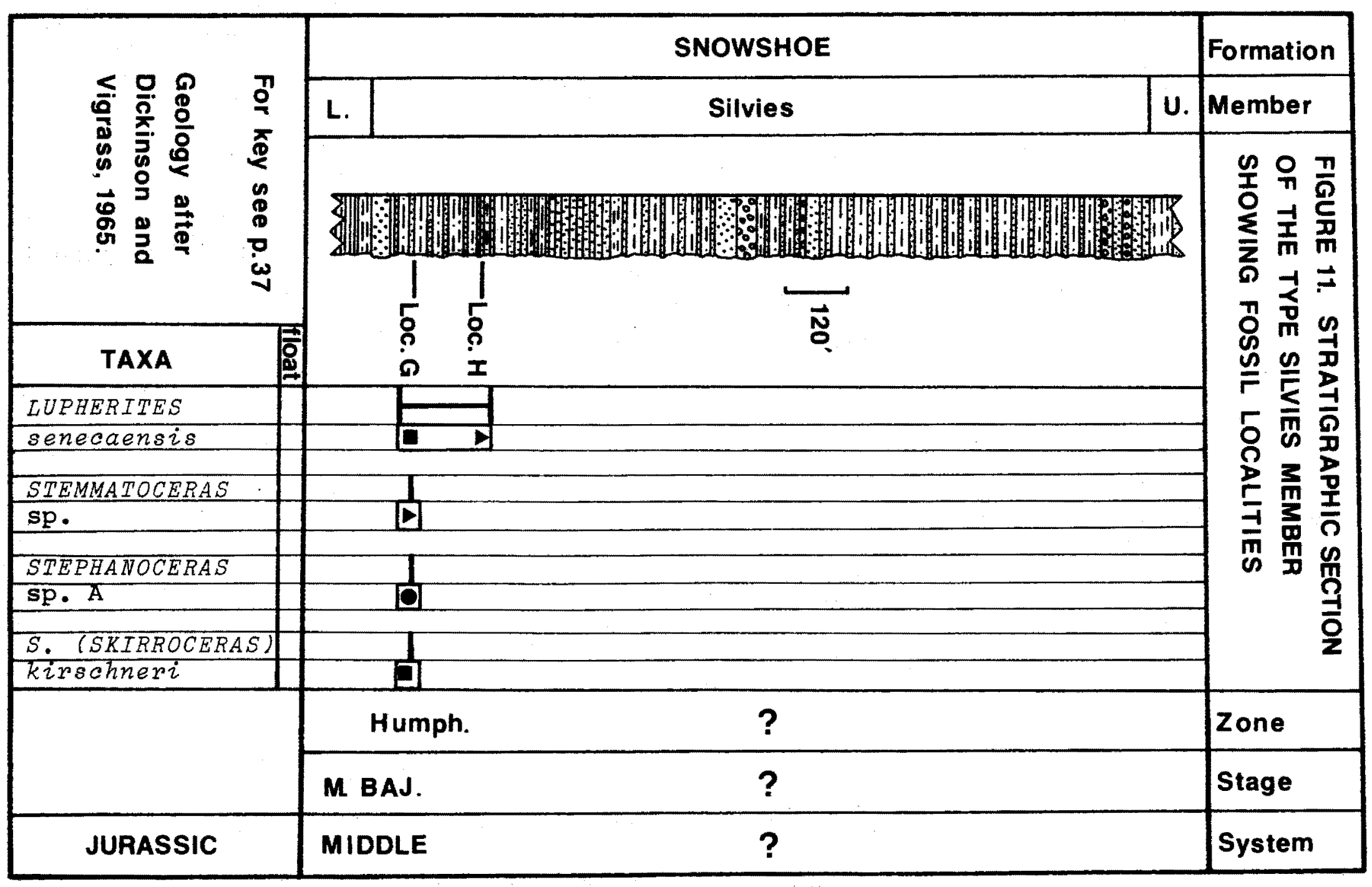




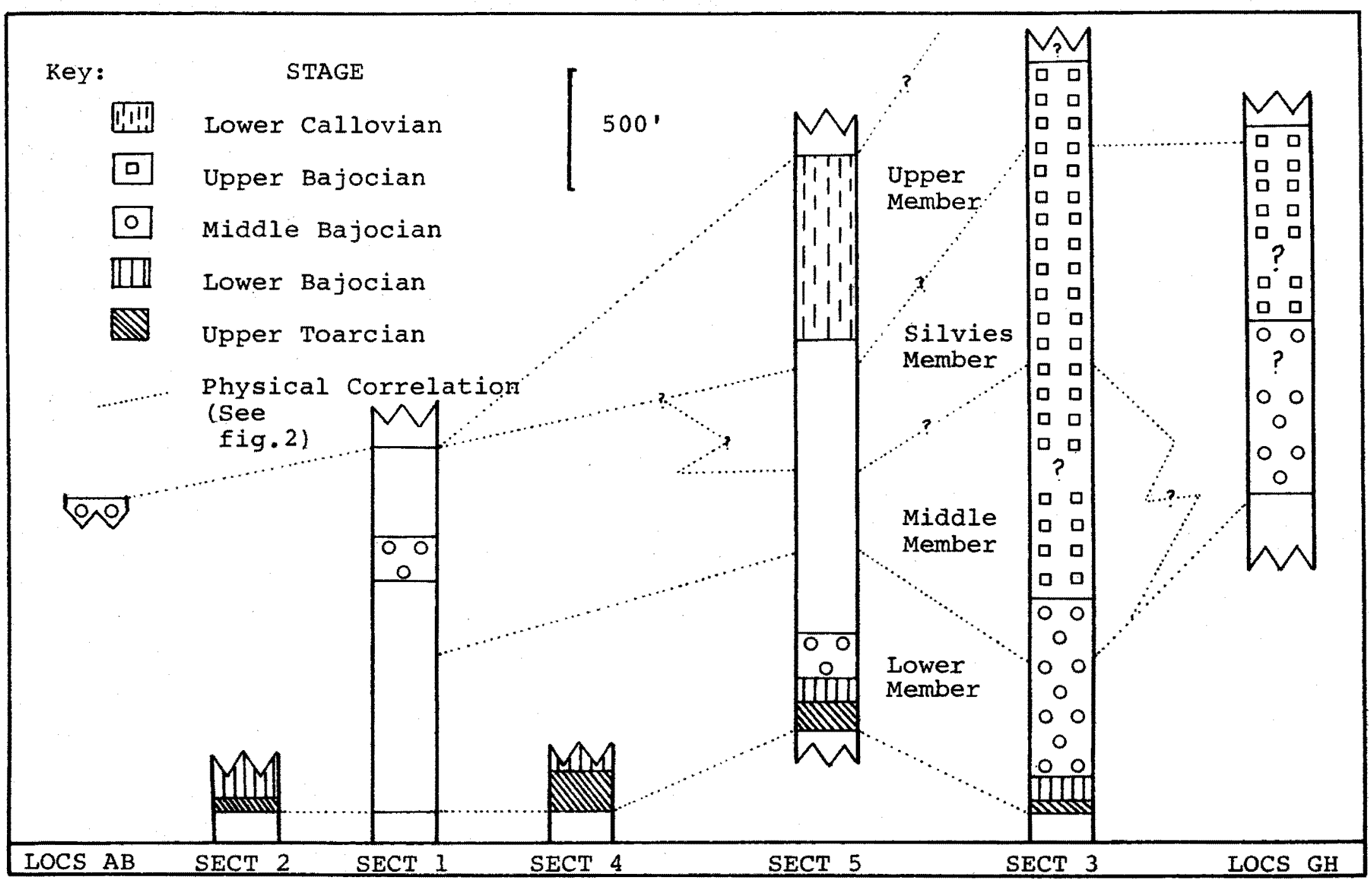

Figure 12, The age of the snowshoe Formation in the Izee area. 
Age and Correlation - The Lower Member

The basal 180 feet (less at some localities) of the lower member yielded Dumortieria, Polyplectus and Lower Jurassic species of Hammatoceras and Pseudolioceras. A correlation with the uppermost zone of the Toarcian, the Levesquei zone, is suggested by the presence of species of Dumortieria (including CatuZZoceras) which is restricted to that Zone (Dean, et al., 1961, p. 489) and Hammatoceras speciosum Janensch which is found in the upper Thouarsense and lower Levesquei Zones in Europe (Guex, 1975, p1. 12). Imlay recognized the Variabilis zone in eastern Oregon (1968, p. C14) but this was based on the occurrence of Haugia which is here assigned to Hammatoceras.

The base of the Middle Jurassic is marked by the incoming of Tmetoceras scissum (Benecke) which is restricted to the lower Bajocian. If Planammatoceras? has been correctly identified, a correlation with the Murchisonae Zone is suggested on Flat Creek where T. scissum and PZanammatoceras? are associated.

The 100 to 150 feet of rocks assigned to the lower Bajocian correlate broadly with the lowest beds of the Weberg Member in the Suplee area. Many of the ammonites of the lower Weberg Member as well as other ammonites characteristic of the lower Bajocian in Canada and Alaska such as Praestrigites, Eudmetoceras, Erycites and Pseudocidoceras have not been found in the Izee area. 
The middle Bajocian is marked by the incoming of the Sonniniidae and stephanoceratidae. The following discussion refers primarily to section 3 where Bajocian deposits are the most continuously fossiliferous. The lowest, Discites zone is only evident by two poorly preserved specimens of Sonninia (Euhoploceras), one of which occurs on Section 3 only 50 feet below beds of Laeviuscula Zone age in a 175 foot thick, otherwise unfossiliferous sequence above the highest occurrence of $T$. scissum. Some undeterminable portion of this 175 foot interval represents the time during which the middle and upper parts of the Weberg Member were deposited. If one were to assume an equal rate of deposition at both sections 3 and 4 , and extrapolate the position of the highest occurrence of $T$. scissum from Section 4 (205 feet above the base), this interval is reduced to just over 50 feet. In the suplee area, the beds of the snowshoe Formation above the range of T. scissum and below that of Witchellia sensu stricto comprise approximately 100 stratigraphic feet that yield an extremely abundant, well preserved and varied fauna. The temporally equivalent beds in the Izee area, on the other hand, can only be described at best as poorly fossiliferous. This could be due: (a) to collection failure, (b) to slow or non-deposition, in which case a condensed sequence or layer would be expected, (c) to erosion, producing an unconformity, (d) to ecologic conditions that 
were inhospitable to the ammonites flourishing in the Suplee area.

The many hours of bed-by-bed collecting in well exposed sections by several workers during the course of this study does not favor explanations (a) and (b). The fact that there is a suitably positioned stratigraphic interval that has yielded two ammonite fragments of probable Discites zone age suggests explanation (c) is unlikely. Explanation (d), unfavorable ecologic conditions, therefore seems most promising. Furthermore, Taylor (personal communication, 1976) is marshalling evidence that the Weberg Member ammonites within the suplee area itself were limited by ecologic controls. There appears to be a correlation in that area between the distribution of some of the ammonites and the lithology of the host rocks which, incidentally, were believed to have been deposited in shallower water than in the Izee area (Dickinson and Vigrass, 1965, p. 58).

The 60 stratigraphic feet or so of the lower member on Section 3 that is assigned to the Laeviuscula zone is characterized by an association of Witchellia connata (Buckman) and W. (Latiwitchellia) evoluta Imlay. The upper boundary of the zone is drawn above the last occurrence of W. connata and below the first occurrences of Dorsetensia (except for one specimen), Sonninia (Papilliceras) sp., species of Stephanoceras (Skirroceras) and Pelekodites 
sizviesensis Imlay (in abundance). The boundary between the Sauzei and Humphriesianum zones is drawn above the highest occurrences of Sonninia (PapilZiceras) sp., Pelekodites silviesensis, Lissoceras hydei and below the first occurrences of Poecilomorphus varius Imlay and Normannites sp. The incoming in abundance of Dorsetensia spans the boundary between the Sauzei and Humphriesianum Zones whereas species of Stephanoceras and $S$. (Skirroceras) are not abundant until the Humphriesianum Zone.

The Laeviuscula and Sauzei zone age deposits correlate with the Warm Springs and lower Basey Members of the Snowshoe Formation in the suplee area. The Warm Springs Member is also similar lithologically to the lower member and it has been suggested that the name might be applicable in the Izee area if it weren't for the fact that the upper boundary of the lower member is diffuse (Imlay, 1973, p. 14). The Laeviuscula zone is only recognizable on Section 3 where it encompasses approximately 60 feet of deposits that correlate with the lower part of the Warm springs Member. The overlying 80 feet or so correlate with the remainder of the Warm Springs Member, the lower part of the Basey Member and Imlay's lower assemblage from the Snowshoe Formation of the Seneca area (Imlay, 1973, p. 28). This entire interval in these areas is characterized by the ammonites Witchellia connata, Pelekodites silviesensis, Sonninia (Papilliceras), Lissoceras hydei and Dorsetensia 
subtecta Buckman. Notably absent from the Izee area are ammonites such as Fontannesia intermedia Imlay which is restricted to a narrow interval at the base of the Warm Springs Member, Emizeia buddenhageni Imlay and otoites contractus ( $J$. de C. Sowerby) which are both common in the upper part of the Member. Again, ecologic controls may have been at play.

The remaining 200 feet of the lower member are assigned to the Humphriesianum Zone and are discussed in the next section dealing with the middle member.

\section{Age and Correlation - The Middle Member}

Approximately the upper 200 feet of the lower member and the basal 2 or 3 hundred feet of the middle member on Section 3 correlate with the Basey Member of the Snowshoe Formation in the Izee area. These stratigraphic intervals are characterized by the following ammonites, which indicate an assignment to the Humphriesianum Zone, probably the lower part: Dorsetensia edouardiana (d'orbigny), D. oregonensis Imlay, Poecilomorphus, Stephanoceras nodosum (Quenstedt), Chondroceras alzani (McLearn) and Normannites, with Stephanoceras (Skirroceras) kirschneri Imlay appearing in abundance. Within 200 feet of the base of the middle member appear representatives of the genus Stemmatoceras together with Lupherites senecaensis Imlay and Cadomites?, none of which are found associated with Chondroceras alzani, S. (S.) 
kirschneri, S. (S.) juhlei and Sphaeroceras sp., the interval also being characterized by an absence of the genus Dorsetensia. Like the upper part of the Basey Member, these beds on Section 3 are assigned to the Humphriesianum zone, probably the upper part, and correlate with Imlay's middle assemblage of the Snowshoe Formation in the Seneca area (Imlay, 1973, p. 28), part of the Silvies Member and probably the Snowshoe Formation in the Emigrant Creek area (op. cit., p. 30).

The middle member in the southwestern part of the area has yielded fossils characteristic of the Sauzei zone, 400 feet above its base on Section 1 and 60 feet below the top of the Formation at Localities $A$ and $B$ where the Trowbridge rests directly on the middle member. The basal middle member, therefore, is younger in the southwest than in the northeast.

The transition from the middle to the upper Bajocian is rather difficult to delimit because of the sparsity of the data. The ammonite assemblage that occurs on Section 3 some 250 feet above the association characteristic of the upper part of the Humphriesianum zone is very tentatively assigned to the upper Bajocian because of the occurrence of a species of Normannites that is similar to N. vigorosus (Imlay) of the upper Bajocian (Imlay, 1962a, p. A2), a specimen referred questionably to the genus Garantiana and undescribed fragments resembling Oecotraustes. Since the 
upper Bajocain ammonites Leptosphinctes cf. L. evolutus Imlay and Leptosphinctes sp. occur in the upper member between 218 feet and 345 feet above its lower contact with the Silvies Member on Section 3, this would mean that the upper three quarters of the middle member, the entire Silvies Member and at least the basal part of the upper member are possibly entirely late Bajocian in age on that section. This interpretation should be tempered by the information presented in the next section concerning the age of the Silvies Member. Also, the assemblage from Section 3 in question is associated with Normannites (Normannites) orbignyi Buckman, which is characteristically found in the upper part of the Humphriesianum Zone, particularly the Blagdeni subzone (Westermann, 1954, p. 135).

\section{Age and Correlation - The Silvies Member}

Dickinson and Vigrass described the type sequence of the Silvies Member as unfossiliferous (1965, p. 51). In fact, the Member as a whole was thought to be unfossiliferous, only a few unidentifiable ammonite fragments having been found (Imlay, 1973, p. 15). A thorough search of the argillaceous interbeds in the type area of the Silvies Member, however, yielded a large fauna consisting of an association of Lupherites senecaensis Imlay, Stephanoceras sp. A., Stephanoceras (Skirroceras) kirschneri Imlay and Stemmatoceras sp. (Localities $\mathrm{G}$ and $\mathrm{H}$ ). This association is identical with that found between 700 and 800 feet above 
the base of section 3 in the middle member rocks that correlate with the upper part of the Humphriesianum zone. The basal contact of the Silvies Member, therefore, is probably diachronous, bearing in mind the arguments presented in the previous section. Since upper Bajocian ammonites have been collected from directly above the unit (Section 3 and Imlay's locality 95, 1973, p. 41, 49), the Silvies Member probably spans the boundary between the middle and upper Bajocian. It certainly is no younger than the upper Bajocian and no older than the Humphriesianum zone.

Age and Correlation - The Upper Member

The stratigraphically highest occurrence of a late Bajocian ammonite occurs on Section 3, 3,115 feet above the base of the Formation, indicating that at least the lower 345 feet of the upper member is of late Bajocian age.

All the beds in the Snowshoe Formation assigned to the upper Bajocian correlate with unnamed beds in the Juniper Mountain and Huntington areas (Imlay, 1973, p. 30, 31).

On Section 5, 1,770 feet above the base, occurs an assemblage of Lizloettia lizloetensis Crickmay, L. buckmani (Crickmay), L. milleri ? Imlay, L. mertonyarwoodi ? (Crickmay), Xenocephalites vicarius ImIay and Bullatimorphites ? sp. which is assigned to the lower Callovian. The 
overlying Trowbridge and Lonesome Formations are also of this age (Imlay, 1964, p. D9). The Bathonian Stage has not been identified in the collections made during this study. In fact, Bathonian ammonites have not yet been recorded in the Pacific coast region south of Smithers in north-central British Columbia (Imlay, in litt., 1974). Poorly preserved fragments occurring 220 stratigraphic feet below the Callovian assemblage on section 5 are questionably assigned to the genus Procerites. This genus is typically Bathonian but has been collected from lowermost Callovian rocks in southern Alaska (Imlay, 1975, fig. 2). The upper member, therefore, appears to range in age from the upper Bajocian to the lower Callovian with an unfossiliferous or covered interval of 1,000 stratigraphic feet on Section 5 which may represent in part the Bathonian stage.

\section{Paleoecology}

As members of the nekton, ammonites were supposedly. free from the limitations imposed on other organisms by environmental conditions; hence their great value in biostratigraphy. However, Kennedy and Cobban have recently suggested that even apparently facies independent ammonite species may vary in their relative abumdance between facies (1976, p. 44). The vast majority of ammonites collected from the snowshoe Formation were found in argillaceous rocks. The succession contains a higher proportion of coarser clastic material in its middle and upper parts 
where ammonites are rare to absent. The great input of volcaniclastic material from the east by turbidity flow (Dickinson and Vigrass, 1965, p. 59), that now constitutes the Silvies Member of the Snowshoe Formation, could well have marked the beginning of a period of conditions sufficient to drive ammonites from the area. This rarity of ammonites is a characteristic that persists throughout the remainder of Jurassic time in east-central oregon when immensely thick sequences of sediments were rapidly laid down. Even so, unaccountably barren thicknesses in the lower, fossiliferous part of the Snowshoe Formation, without any change in lithology, suggests that subtle or far removed ecological controls were at play that did not leave their mark in the local sedimentary record.

The only ammonites which have any water depth connotations at present are the "leiostracans" (phylloceratids and 1ytoceratids) which, on grounds of facies associations and shell structure, were thought to inhabit deep water (Westermann, 1971, p. 33). They are generally absent from shallow inland and epicontinental seas but their distribution may include the outer margin of the shelf (Westermann, 1975, p. 34). In the Snowshoe Formation the proportion of phylloceratids and lytoceratids to all the other ammonites is low ( 3 percent) but their presence is enough at least to suggest ease of access, if not proximity to the open ocean. Such a conclusion is strengthened by 
an abundance of radiolaria.

The small and fragile pelecypod, Bositra buchi (Roemer), is found throughout the sequence and in abundance in the lower and middle parts. Jefferies and Minton (1965) have elegantly argued that Bositra was a nektoplanktonic organism and this is in keeping with its world wide occurrence. The pelecypod is ubiquitous in the quietwater, euxinic facies typified by the "Posidonia shales" $l=$ Bositra $)$ of Europe. Conditions must indeed have been quiet during the deposition of the snowshoe Formation for the delicate shells to be fossilized unbroken. Sedimentologic evidence also suggests quiet conditions for the middle part of the sequence where fine, alternating laminae of siltstone and mudstone are found. For such structures to be preserved, deposition must have been rapid or perhaps euxinic bottom conditions suppressed the benthonic fauna, preventing bioturbation (see Pettijohn, 1975, p. 105). The rarity of benthonic organisms from much of the snowshoe Formation favors the latter idea but probably both causes were effective. A likely water depth of 650 feet to 1,650 feet (c. 200 to 500 meters, upper bathyal, continental slope) has been suggested for some European deposits rich in Bositra but these limits are by no means rigid (Westermann, 1975, p. 35; see also, sturani, 1971, p. 43). Oysters (sensu Zato) are often found encrusting ammonites, usually concentrated in the umbilicus of large 
forms. As a consequence, many of the oysters have grown xenomorphically, forming a partial external mold of the ammonite, in the fashion described by Lewy (1972) and Stenzel (1971, p. N1022). The fact that oysters are absent from bedding planes where they encrust ammonites suggests a muddy bottom unsuitable for oyster colonization. Although euryhaline oysters are thought to have arisen in the Middle Jurassic (Hudson and Palmer, 1976), there can be no doubt that normal marine conditions prevailed during the deposition of the Snowshoe Formation since the oysters collected were always associated with stenohaline cephalopods and pelecypods. Normally the presence of oysters suggests shallow water and such conditions of deposition have been postulated for at least the upper part of the Snowshoe Formation (Imlay, 1964, p. D6). However, none of the oysters collected during this study are the thick shelled, large forms characteristic of shallow waters in modern seas.

The Snowshoe fauna as a whole is characterized by locally abundant ammonites and aptychi, ubiquitous Bositra buchi, oysters and other rare pelecypods, organic matter and radiolaria. Such a composition compares well with the fauna of the typical Bositra buchi facies which was described by Jefferies and Minton (1965, p. 158) as consisting

...mainly of shale, often bituminous, with subordinate limestone and radiolarian chert. Apart from $B$. buchi, which is often exceedingly 
abundant, almost the only macrofossils are ammonites, often including Phylloceras and Lytoceras, together with aptychi and cephalopod (? armonite) beaks (Rhynchoteuthis), though tracks, including zoophycus, may be present.

The Snowshoe Formation and fauna, particularly in the lower part of the sequence, are probably partial developments of this facies but perhaps of lower neritic rather than bathyal depths. The facies is widespread throughout the world, having been recorded in the Middle Jurassic rocks of Tethyan aspect in Europe, Africa, Turkey, Persia, Iraq, Indonesia and South America (Arkel1, 1956, passim; Jefferies and Minton, 1965, p. 158; Westermann, 1975, p. 35).

\section{Conclusions}

In summary, the snowshoe Formation fauna ranges in age from the Lower to the Upper Jurassic, spanning the uppermost Toarcian, Bajocian and lower Callovian stages. The zonal succession seems to be fairly complete in the lower part of the sequence but after the middle Bajocian, the dearth of ammonites does not allow the recognition of zones. The age relationships between the various members of the Snowshoe Formation, as postulated in this paper, are shown in fig. 13.

The Toarcian portion of the lower member has no known correlatives in oregon. This is also true of most of the Jurassic sequences in Canada where the Toarcian is often represented but not the Levesquei zone (Frebold, 1958, table 1; 1960, table 1; 1964, table 1; 1975, table 1; 


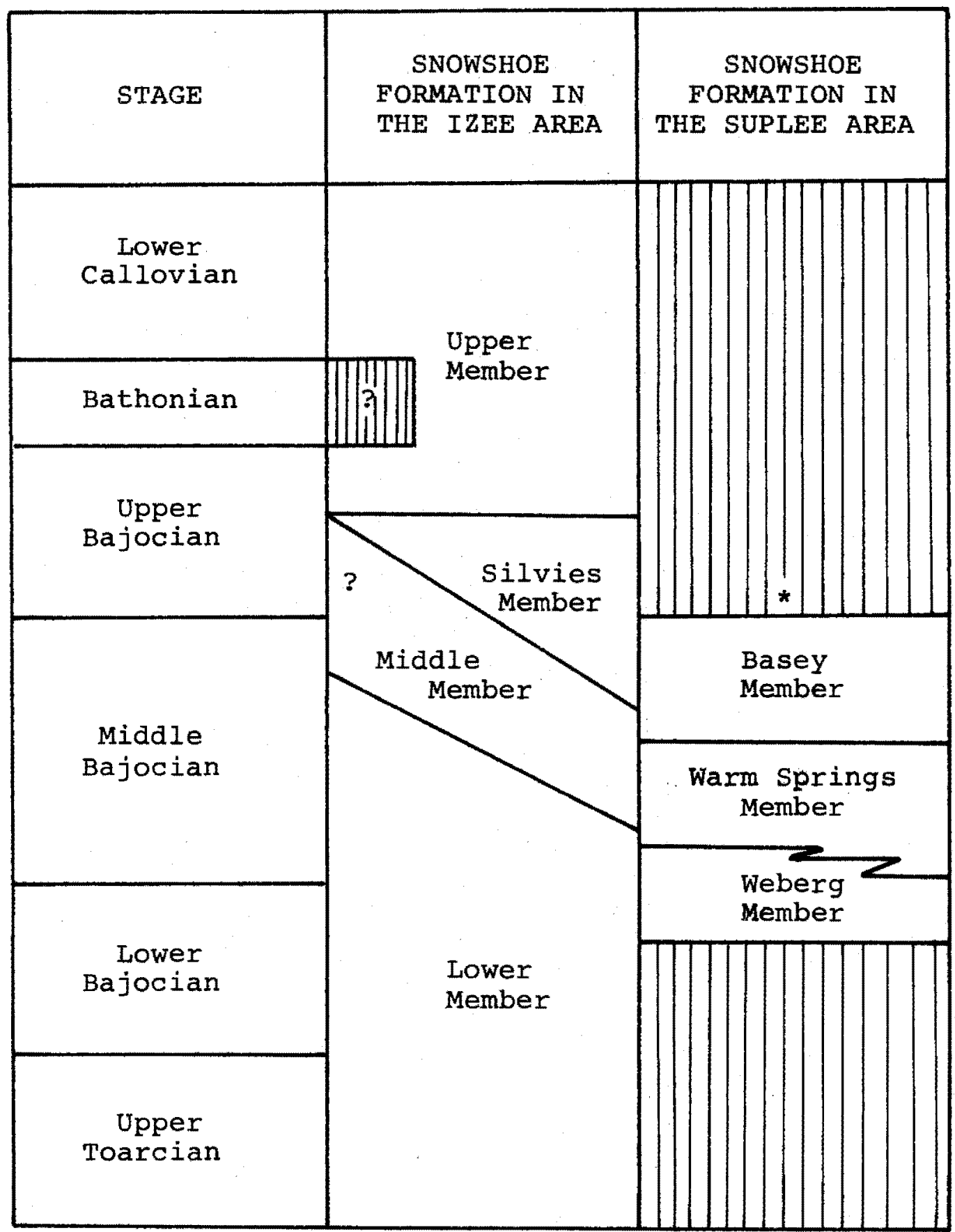

Key:

* The "Shaw Member" is not included within the Snowshoe Formation in this report (see Imlay, 1973, p. 9).

[IIIII Not represented.

Not to scale.

Figure 13. Correlation of members of the Snowshoe Formation in the Izee and suplee areas. 
Frebold et al., 1969, table 1). One possible exception is recorded in the southern Yukon where specimens of Catulzoceras ? spp. indet. have been collected from the Laberge Group (Frebold, 1964, p. 16, 26, table 1). The Levesquei zone is probably represented in unnamed sedimentary rocks cropping out in the Puale Bay and Alinchak Bay areas on the Alaska Peninsula and in the Utukok and Etivluk Rivers area of northern Alaska (Imlay and Detterman, 1973, fig. 11). Parts of the Kingak Shale in northern Alaska are probably correlative with the lowermost Snowshoe Formation but the case for the age of all of the Alaskan deposits is based on stratigraphic position rather than on the basis of fossils. The diverse Levesquei zone fauna in eastern oregon appears, at present, to be unique in the Pacific Coast region of the North American continent. The nearest comparable fauna occurs in the Mendoza Province of western Argentina (Jaworski, 1926).

The upper part of the lower member, the middle and Silvies members and the lower part of the upper member that are assigned to the Bajocian Stage constitute in excess of 2,000 stratigraphic feet of sedimentary rocks. This interval correlates wholly or in part with the following formations: the Kialagvik Formation, Red Glacier Formation, Gaikema Sandstone, Fitz Creek Siltstone, Cynthia Falls Sandstone, Nizina Mountain Formation and the Gemuk Group of Alaska (Imlay, 1953b, table 5; 1962b, fig. 7; 1964b, fig. 5; 1973, 
fig. 1; Imlay and Detterman, 1973, fig. 1IA); the Sawtooth and Piper Formations of Montana (Imlay, 1953a, table 2; 1962b, fig. 7; 1967, fig. 10); the Twin Creek Limestone of Idaho, wyoming and Utah (Imlay, 1953a, table 2; 1967, fig. 10); the Gypsum Spring Formation of Wyoming and Dakota (Imlay, 1953a, table 2; 1967, fig. 10); the Navajo Sandstone (?), Arapien Shale (?) and Carmel Formation (?) of Utah (Imlay, 1953a, table 2; 1967, fig. 10); the Thompson Limestone, the Mormon Sandstone and Sailor Canyon Formation of California (Imlay, 1964b, fig. 5; 1973, fig. 1, p. 35). Fossiliferous but unnamed Bajocian beds in Canada are described by Frebold (1964, table 1; Frebold and Tipper, 1967, pl. 2; Frebold et al., 1969, table 1). Other Bajocian sequences from Canada include the Yakoun Formation and parts of the Thompson, Fernie and Hazelton Groups (Frebold, 1953, pl. 1; Frebold and Tipper, 1967, p. 8; 1973, p. 1,109).

If the Bathonian stage is represented in the Snowshoe Formation of the Izee area, its correlatives would include the following: the Sawtooth Formation, Piper Formation, Gypsum Spring Formation, Carmel Formation, Arapien Shale, Twin Creek Limestone and Bowser Formation. All of these units are partly Bajocian in age except for the Bowser Formation of Alaska which is entirely Bathonian (Imlay, 1964b, fig. 5; Imlay and Detterman, 1973, fig. 11A). In Canada, part of the Hazelton Group is of Bathonian age (Frebold and Tipper, 1973, p. 1,109). 
The lower Callovian portion of the Snowshoe Formation correlates wholly or in part with the following units: the Shelikof Formation, Chinitna Formation and Kotsina Conglomerate (?) of Alaska (Imlay, 1962b, fig. 7; 1964b, fig. 5; 1975, fig. 8; Imlay and Detterman, 1973, fig. 11A); the Rierdon Formation of Montana (Imlay, 1962b, fig. 7; 1967, fig. 10); the Twin Creek Limestone of Idaho, Wyoming and Dakota (Imlay, 1953a, table 2; 1967, fig. 10); the "Lower Sundance" Formation of Wyoming and Dakota, and the Arapien Shale and Carmel Formation of Utah (Imlay, 1953a, table 2; 1967, fig. 10); the Consumnes Formation, Bicknell Sandstone and Hinchman Sandstone (?) of California (Imlay, 1961, fig. 1); the Mysterious Creek Formation, Minabariet Formation, parts of the Yakoun Formation, the Savik Formation and various unnamed sequences in Canada (Frebold, 1953, pl. 1; Frebold and Tipper, 1967, table 2).

From the detailed evidence accrued during this study, a model can be outlined that explains the distribution in space and time of the sedimentary rocks that now constitute the Snowshoe Formation in the Izee area. The gradational contact between the Hyde and the Snowshoe Formations attests to a gradual change in the nature of the sedimentation. Furthermore, this change began synchronously throughout the Izee area since upper Toarcian fossils are found in the basal part of the lower member on most sections. The lower member maintains fairly constant thickness throughout the area so 
that, as might be expected from a dominantly argillaceous unit, its geometry offers no clue as to provenance. As quiet deposition of suspended andesitic silt, clay and organic matter proceeded in the Izee area, the Suplee area to the west was experiencing transgression across the nascent "Suplee platform" (Dickinson and Vigrass, 1965, p. 58). Here lies an obvious possible source area for the sedimentary rocks of the lower member but certainly this was not the only source.

The hypothesis presented by Dickinson and Vigrass concerning the origin and relationships between the Silvies and middle members (1965, p. 59) is entirely compatible with the evidence gathered during this investigation. These workers suggest that the Silvies Member is a

wedge-shaped apron of andesitic detritus deposited by turbidity currents moving downslope toward the "Izee basin" from a constructional volcanic pile lying more than 25 miles east of Izee beyond Seneca (Zoc. cit.). The graded volcanic siltstone laminae of the middle member are interpreted as the distal ends of these turbidity flows. In the southwestern part of the Izee area, the middle member is decidedly older than to the north. It is suggested, therefore, that the distal ends of these turbidity flows first reached the southwestern part of the area during Sauzei zone time or earlier whereas they did not reach the northeastern part of the area until Humphriesianum zone time. Eventually the Silvies Member itself arrived in the area, encroaching from approximately 
the east or the northeast, if the evidence concerning the diachronous nature of its basal part holds good.

The deposition of the Silvies Member during the upper part of the middle Bajocian and the upper Bajocian was a geologic event of major proportions that not only appears to have had an influence on the distribution of ammonites but possibly heralded a period of shallowing followed by tectonic disturbance and subsidence. The problem of whether or not the Bathonian is present remains unsolved but it could mark a period of non-deposition or erosion. The upper member was probably deposited in the shallowing water of an almost filled Izee basin. Not only is the Snowshoe Formation a coarsening upward sequence but the overlying Rosebud Member of the Trowbridge Formation was thought to have been deposited in a lagoon or broad bay (Dickinson and Vigrass, 1965, p. 64 ).

The relationship between the snowshoe and Trowbridge Formations remains problematical in some respects. The upper member disappears in a westerly direction where Bajocian fossils are found directly below the contact as opposed to Callovian fossils 600 feet below the top of Section 5. Such a situation could be explained by the Snowshoe/Trowbridge contact being diachronous so that the Rosebud Member in the southwest could be equivalent in age to the upper member in the northeast. Unfortunately, the Rosebud Member has never yielded any fossils but is assigned 
to the lower Callovian merely because it rests on the upper member of the Snowshoe Formation in some areas and the Magill Member, the uppermost member of the Trowbridge Formation, has furnished lower Callovian fossils. However, a diachronous relationship is not the only possible explanation. The upper member could pinch out at depth before reaching Big Flat or, if there were any angular discordance between the two formations, the upper member could be progressively overlapped by the Trowbridge Formation in a westerly direction as suggested by Dickinson and Vigrass (1965, p. 60, 84). The Snowshoe/Trowbridge contact could well be conformable north of the South Fork of the John Day River but represent a diastem to the southwest, closer to the then active Mowich upwarp.

The progressive thickening of the Snowshoe Formation to the northeast described on p. 6 can therefore be attributed to two causes. Firstly, a tongue of the silvies Member adds thickness to the Formation in that part of the area. Secondly, fossil collections indicate that the Snowshoe Formation represents a longer period of time in the northeast than in the southwest.

As more detailed geologic maps become available the study of the biostratigraphy of the snowshoe Formation should be continued to the east where the unit, particularly in its upper parts, is often more fossiliferous. Eventually, a detailed understanding of Oregon's geologic history during 
this part of the Jurassic Period could be achieved across an area stretching from Suplee to the Idaho border. 
SYSTEMATIC SECTION

Notes on Preservation and Quantification

Certain ammonites collected from east-central Oregon provide a valuable right side-up criterion in an area where beds may be near vertical or overturned. The lowermost surface of the ammonite, $i . e$. the surface that came to rest on the sea floor, is often well preserved while the upper surface is crushed. Also, aptychi tended to come to rest in a stable position with the convex side of each valve facing upward. Rigorous evaluation of these casual observations would be a useful study.

Usually ammonites show a relatively well preserved body chamber. The absence of septa allows the free passage of sediment into the body chamber after the soft parts have decayed (Arkell, 1957, p. L86). This author has collected specimens from the English Lias, for example, where the body chamber is preserved as an internal mold almost in its original form whereas the phragmocone, unsupported by sediment, is crushed in the plane of coiling by the weight of the superincumbent deposits. Differences in preservation of this sort have been noted by several authors from Europe (e.g. Arkell, 1951, 1957). Some of the eastern Oregon ammonites, however, show a body chamber that is 
relatively more crushed than the phragmocone. This may be a reflection of the different rates of sedimentation that prevailed in Oregon during the Jurassic compared to the relatively slow rates experienced in the classic areas of Europe. The Jurassic sequence in southern England, for example, is a mere 5,000 feet $(1,524$ meters) or so thick (Cope, et al., 1969, table 1) whereas the dominantly volcaniclastic Jurassic succession in east-central oregon is four times thicker with at least three stages unrepresented (Dickinson and Vigrass, 1965, pl. 3). Rapid deposition would cause burial before decay of the soft parts thus preventing a complete infilling of the body chamber, leaving it weaker relative to the septate phragmocone (see Jackson, 1970, p. 381).

Preservation is generally poor. The vast majority of the ammonite specimens described herein are fragmentary or crushed in the plane of coiling and occasionally slightly crushed at right angles to this plane. This greatly inhibits quantification. Whorl width and height cannot usually be measured whereas umbilical measurements and shell diameters are exaggerated to some degree by crushing. However, features of ribbing are important in identification and rib densities are best expressed in terms of density per half whorls at given umbilical diameters. Only specimens that show a similar state of preservation are used for graphical work and a comment is made on the nature of the 
preservation. This will aid later workers attempting to study similarly preserved ammonites collected from the Snowshoe Formation in other areas. Suture lines are rarely evident and are usually corroded or distorted when preserved. Consequently, little use could be made of suture lines in identifying the specimens.

Parameters measured are listed below. All dimensions are in millimeters. All regression lines drawn on graphs are linear. Regression equations are given followed by the correlation coeffecient in parentheses. Approximate measurements are preceeded by "c." (circa).

D Diameter of specimen (see fig. 14).

Ud Diameter of umbilicus (see fig. 14).

$\mathrm{u}$ A measure of the degree of involution where $\mathrm{u}=\frac{\mathrm{Ud} \times 100}{\mathrm{D}}$ (to the nearest whole number).

Rd Ribs per half whorl at given umbilical diameter using the prefix "p" or "s" for primary and secondary ribs respectively (see fig. 14).

Wh Whorl height.

Wb Whorl breadth.

The geographic distribution of specimens is shown in Table II in the section on paleontology whereas the the stratigraphic distribution is illustrated in figs. 6 to 11 in the section dealing with biostratigraphy. Information regarding specimen numbers from section 


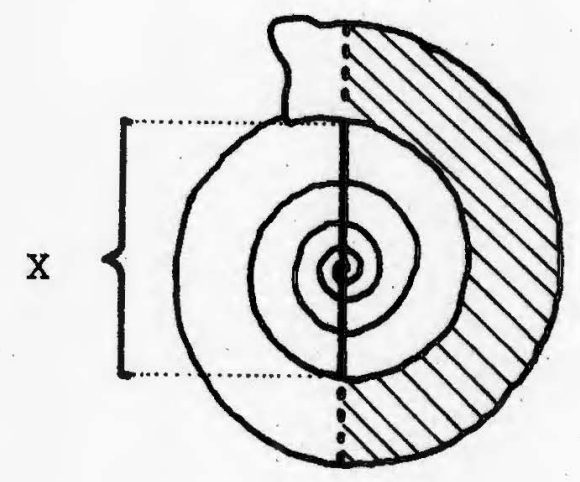

Key: $\quad \mathrm{x}$ Umbilical diameter measured between umbilical seams.

D. Half whorl for the given umbilical diameter $\mathrm{x}$.

Figure 14. The umbilical diameter of ammonites.

collections is presented in Appendix C. Appendix A (section and locality descriptions) describes the fossil numbering system for isolated localities.

Identification of the specimens collected during this study was mostly achieved by comparing the oregon material with specimens figured and described by other authors. The only museum material available for study consisted of a few specimens of Dorseterisia from Lupher's collection (two of which are refigured here, see pl. 4, figs. 9, 10) and some rubber molds of Catuzzoceras collected from eastern Oregon and kindly made available by Dr. Imlay. A collection of sonniniids from Scotland, collected by Dr. Morton, was seen briefly during the summer of 1975 . 
Systematic Descriptions

\author{
Phylum MOLLUSCA \\ Class BIVALVIA Linné, 1758 \\ Order PTERIOIDA Neẅell, 1965 \\ Family POSIDONIIDAE Frech, 1909 \\ Genus Bositra De Gregorio, 1886 \\ Bositra buchi (Roemer)
}

1945 ? Posidonia cf: P. ornati Quenstedt; Imlay, p. 264, pl. 39, figs. 22-24.

1955 Posidonia cf. P. ornati Quenstedt; Imlay, p. 86, pl. 10, fig. 21 .

1959 Daonezza Sanctaeanae Smith; Engel, p. 20, figs. 3-4.

1963 Posidonia ornati Quenstedt; Imlay, p. 102, pl. 14, figs. 10-13.

1964 a Posidonia ornati Quenstedt; Imlay, p. D13, pl. 1, fig. 22 .

$1964 \mathrm{c}$ Posidonia ornati Quenstedt; Imlay, p. 507, pl. 78, figs. 1-2.

1965 Bositra buchi (Romer); Jefferies and Minton, pl. 19, figs. $1-4,6-9$.

1971 Bositra buchi (Romer); Sturani, p. 44, pl. 16, fig. 5 .

Material: Several hundred specimens with thousands seen in situ but not collected.

Description: All the specimens are small, usually in the order of $9 \mathrm{~mm}$ in length, slightly less in height, and mostly preserved as external molds with the valves often open and 
separated. Hinge line fairly straight; dorsal angles rounded; broadly rounded ventral margin becoming more straight anteriorly and posteriorly. The surface displays marked, rounded costae (with sharp interspaces) that are concentric about the low prosogyral umbos.

Discussion: The differences between Bositra (Toarcian to Oxfordian) and Posidonia are described by Jefferies and Minton (1965, p. 157), who also discuss the synonomy of the specific name.

Class CEPHALOPODA Cuvier, 1797
Order AMMONOIDEA Zittel, 1884

Family PHYLLOCERATIDAE zittel, 1884

Genus PhyZZoceras Suess, 1865

PhyZloceras kunthi ? Neumayr

Pl. 1, fig. 1

? 1871 PhyZZoceras kunthi Neumayr; p. 312, pl. 13, figs. $1 a, b$.

? 1964b PhyzZoceras cf. P. kunthi Neumayr; Imlay, p. B31, pl. 2, figs. 3-4.

1973 PhyZZoceras sp.: Imlay, p. 54, pl. 1, fig. 17; pl. 2, fig. 9 .

Material: Eleven fragmentary specimens.

Description: Very poorly preserved fragments of a compressed species that reached a large size, probably well in excess of $10 \mathrm{~cm}$. Each fragment bears dense lirae or fine ribs. 
Discussion: These specimens compare in style of ribbing with the ammonites figured by Imlay (Zoc. cit.) and will probably be referrable to $P$. kunthi as suggested by Imlay (1973, p. 54), when better preserved material becomes available.

$$
\begin{aligned}
& \text { Phylloceras sp. } \\
& \text { Pl. 1, figs. } 2-3
\end{aligned}
$$

Material: Six specimens.

Dimensions: Specimen no. D Ud u wh Wb

$\begin{array}{lrrrrr}\text { Float 2-52 } & 21 & 1 & 5 & 11 & 10 \\ \text { F5-4-3 } & 16 & 1 & 6 & 10 & 6 \\ \text { F5-5-29 } & 30 & \text { c. } 2 & 7 & 19 & 13\end{array}$

Description: Three crushed fragments and three well preserved specimens that are extremely involute to convolute with an ovate, slightly compressed whorl section. The specimens are featureless in terms of ornamentation. The suture is exposed on specimen Float 2-52 revealing a complex line with triphyllic saddles.

Discussion: These specimens are assigned to PhylZoceras on the basis of their suture line, degree of involution and lack of costation. Phyzloceras sp. can be differentiated from HolcophyZZoceras costisparsum Imlay in being more involute and in not possessing constrictions. Genus HoZcophyZZoceras Spath, 1927 
Holcophyzloceras costisparsum Imlay

$$
\text { P1. 1, fig. } 4
$$

1962a CalliphylZoceras sp.; Imlay, p. A5, pl. 1, fig. 8.

1964b HolcophylZoceras costisparsum n. sp.; Imlay, p. B32, pl. 1, figs. 10-12, 14-17.

1969b Holcophylloceras costisparsum Imlay; Westermann, p. 40 , pl. 8, figs. 3a, b; pl. 9, figs. la, b.

Material: Thirteen specimens.

Dimensions: Specimen no. D ud Constrictions u per $\frac{1}{2}$ whorl

$\begin{array}{lrrrr}\text { *F3-30-399 } & 43 & 3 & 2 & 7 \\ \text { F5-3-3 } & 42 & 4 & 4 & 10 \\ \text { F5-5-23 } & 0.33 & 0.3 & 3 & 9 \\ \text { U.Sn.Loc.A(1) } & 18 & 2 & 3 & 11 \\ \text { * Distorted slightly } & \end{array}$

Description: Seven of the specimens are fragments and all but two of the complete individuals are flattened in the plane of coiling. All the specimens are internal molds, occasionally with some shell material still adhering. This species is extremely involute to almost convolute, the narrow umbilicus being bordered by a low umbilical wall that rounds evenly into the somewhat flattened flanks. On an uncrushed specimen (F5-3-3) the whorl height is $22 \mathrm{~mm}$ and the whorl width $16 \mathrm{~mm}$ at a diameter of $42 \mathrm{~mm}$. The whorls are compressed ovate with a broadly rounded venter. Each specimen bears between 2 and 4 constrictions 
(per half whorl), which are seen to be restricted to the internal mold on one suitably preserved specimen. These constrictions are generally rectiradiate with a slight adoral inflection just above the middle of the flank. The constrictions pass rectiradiately or arch slightly forward across the venter. The internal molds are otherwise quite smooth.

Discussion: There is an excellent resemblance between these specimens and the type material described from Alaska except for the absence of the very weak riblets on the upper flanks and venter (Imlay, 1964a, p. B32). Westermann described similar specimens from the Sowerbyi zone (= Discites and Laeviuscula Zones) of Alaska extending the range of this species to include the middle and the upper Bajocian (Westermann, 1969b, p. 41). Acording to Westermann (Zoc. cit.), this species is intermediate between $H$. uLtramontanum (Zittel, 1869, p. 66, pl. 1, figs. 4-6) of the lower Bajocian (+ ? Sowerbyi Zone) and H. mediterraneum (Neumayr, 1871, p. 340, pl. 17, figs. 2-5) which ranges from the upper Bajocian to the Tithonian. H. Ultramontanum bears small, acute, adoral inflections of the constrictions but its umbilicus, which is slightly wider than that of $H$. costisparsum, is comparable to the Oregon specimens. H. mediterraneum also has a wider umbilicus but the constrictions are similar in style and density to $H$. costisparsum. It differs, however, 
in having much stronger costation.

Family LYTOCERATIDAE Neumayr, 1875

Genus Lytoceras Suess, 1865

Lytoceras espinazitum Pugin

$$
\text { P1. 1, fig. } 6
$$

1878 Lytoceras Eudesianum d'Orbigny; Gottsche, p. 8, pl. 1, fig. 1 .

1964 Lytoceras espinazitum n. sp.; Pugin, p. 32.

Material: One specimen.

Dimensions: Specimen no. D Ud Rd u

$$
\begin{array}{lllll}
\text { F5-4-23 } & c .32 & c .15 & c .50 & 64
\end{array}
$$

Description: This specimen is a laterally crushed internal mold with a considerable amount of corroded shell material adhering. It is an evolute form ornamented with fine, dense lirae or riblets that trend slightly rursiradiately from the rounded umbilical wall across the rounded flanks. The costation is interrupted at four points on the outer half whorl by shallow constrictions. The inner whorls are too poorly preserved to determine whether they are also constricted.

Discussion: This specimen appears to be identical to the specimen figured by Gottsche (200. cit.) which he identified with the holotype of $L$. eudesianum (d'Orbigny, 1846, pl. 128). However, d'Orbigny's figure does not show the regular constrictions evident in Gottsche's figure. Pugin (Zoc. cit.) therefore created the new species $L$. espinazitum and designated Gottsche's specimen as the holotype. 
Lytoceras aff. L. eudesianum (d'Orbigny)

Pl. 1, fig. 5

aff. 1846 Ammonites Eudesianum d'Orbigny; p1. 128.

$1969 \mathrm{~b}$ Lytoceras sp. aff. L. eudesianum (d'Orbigny); Westermann, p. 42, pl. 9, figs. 2-3.

Material: One specimen.

Description: This fragmentary specimen shows a crushed outer (? body) whorl whereas the internal whorls are well preserved displaying a circular cross section. The shell is extremely evolute and bears fine rursiradiate riblets ( $R d=$ 34 at Ud $=6$ ) that are not interrupted by constrictions.

Discussion: This specimen differs from d'Orbigny's holotype of $L$. eudesianum (Zoc. oit) by the absence of lamellar flares and in that respect is similar to Westermann's figured specimens. Lytoceras aff. $L$. eudesianum differs from $L$. espinazitum in not possessing constrictions and being less densely costate.

Family HILDOCERATIDAE Hyatt, 1867

Genus Pseudolioceras Buckman, 1889

Pseudolioceras cf. P. spitsbergense Frebold

Pl. 1, fig. 7

cf. 1960 Grammoceras ? sp. indet; Frebold, p. 23, pl. 12, figs. $5 a, b, 6,7$.

cf. 1975 Pseudolioceras spitsbergense Frebold; p. 12, pl. 4, figs. 6-9. 
Material: One specimen.

Description: This specimen is a poorly preserved, flattened fragment that shows a very high whorl section $(35 \mathrm{~mm}$ in its fossilized state) and a tightly arcuate umbilical wall suggesting it was an involute form. The umbilical wall is small, and steep, passing abruptly into the very gently convex flanks. The ribs have been weathered, especially near the umbilicus, but they appear to arise fairly low on the flanks as weak, prorsiradiate ribs that become stronger and falcoid on the upper four-fifths of the flanks. The ribs are fairly wide and rounded with narrower, sharp interspaces. They do not reach the venter but fade into a smooth band that borders the keel. The keel is extremely high (almost $5 \mathrm{~mm}$ ) and possibly laterally sulcate. A section was cut through the keel, revealing that it is hollow.

Discussion: This specimen is assigned to the genus Pseudolioceras rather than Pseudogrammoceras because the ribbing is straight and prorsiradiate on the lower flanks; it is an involute, compressed form; the keel is very high and the umbilical wall is low and steep. The much younger genus Darellia (Buckman, 1910, pl. 1l, fig. 2) has considerably weaker costation whereas Leioceras, the supposed homeomorph of Pseudolioceras, differs in possessing a solid instead of a hollow keel (Arkell, et al., 1957, p. L259). The ribbing on the oregon specimen is much stronger and the 
keel higher than on a Toarcian specimen of Hyperlioceras (= Pseudolioceras, Westermann, $1964 \mathrm{a}, \mathrm{p} .351)$ collected in Japan by Sato (1957, p. 347, pl. 2, figs. 7, 8). Pseudolioceras is a long ranging genus, having been collected from both Toarcian and Bajocian deposits (Imlay, 1968, p. (21).

Pseudolioceras is well represented in Jurassic deposits of the Canadian Arctic (Frebold, 1958, 1960, 1975) and in Alaska (Westermann, 1964a). Most of the species have been associated with Bajocian faunas and differ from the oregon example in possessing a raised, ridge-like umbilical margin (Pseudolioceras whiteavesi (White); White, 1889, p. 499, pl. 13, figs. 1-5) or in the ribbing being more falcate, less persistent on the lower flanks and the keel being lower (Pseudolioceras melintocki (Haughton); see figures in Frebold, 1960, and Westermann, 1964a). The Oregon specimen compares most favorably with the recently erected species, Fseudolioceras spitsbergense (Frebold, 1975, p. 12), but again the ribbing is not quite as falcate. In this respect it compares with an ammonite collected by H. W. Tipper from the Spruce Lake area, British Columbia and very questionably assigned to the genus Oedania by Frebold (Frebold, et al., 1969, p. 23, pl. 2, fig. 5). P. cf. spitsbergense may be differentiated from the Toarcian species figured by Monestier (1921, p. 29-36, 
pls. 1-3) by its higher keel and from $P$. compactize (Simpson) (Imlay, 1955, p. 89; Frebold, 1958, p. 5; Guex, 1972, pl. 5, fig. 13) by the ribbing which is not projected on $P$. compactile.

$$
\begin{gathered}
\text { Genus Polyplectus Buckman, } 1890 \\
\text { Polyplectus spp. ? } \\
\text { Pl. 1, figs. 8-10 }
\end{gathered}
$$

Material: Twenty-nine fragmentary specimens.

Description: One of the larger specimens and the two smallest specimens indicated that this form was narrowly umbilicate and probably an oxycone since all the fragments show what would have been a very high whorl section. The flanks of the whorls bear dense falcate ribs that arise from the umbilical margin and pass onto the very low keel that is evident on a few of the fragments. The strength of the costation varies slightly from specimen to specimen and sometimes on the same specimen (see pl. 1, fig. 8) but it tends to be finest and faintest on the lower two-thirds of the flanks where the ribs crowd toward the narrow umbilicus. On the upper third of the flanks the ribs thicken considerably but are still fine.

Discussion: The indifferent preservation of the material does not allow accurate specific identification but the 
fragments do show the essential characteristics of the genus viz. an involute oxycone bearing fine, falcate ribs. All the fragments suggest that this ammonite reached a fairly large diameter, probably well in excess of $6 \mathrm{~cm}$. Guex (1973, p. 8) has recently recognized a new genus he has named Micropolyplectus which is supposedly the microconch of Polyplectus differentiated on the basis of its small size.

These specimens compare favorably with the two examples of Polyplectus cf. P. subplanatus (Oppel) figured by Imlay (1968, pl. 9, figs. 13, 16). However, the ribbing on specimen F4-3-61 (pl. l, fig. 9), for example, is slightly coarser and is reminiscent of the ribbing displayed by Harpoceras (Polyplectus) discoide (Zeiten) as figured by Parisch and Viale (1906, pl. 8, figs. 1-4; see also, Géczy, 1967, pl. 30, fig. 1). More than one species may therefore be represented.

In the past, this genus has been confused with Harpoceras (Dickinson and Vigrass, 1965, p. 48, 49) which is represented in Canada (Frebold, 1964, p. 16). However, Polyplectus may be differentiated from Harpoceras by its much narrower umbilicus (Imlay, 1968, p. C44). Ribbing also tends to be finer and denser on Polyplectus.

It might transpire, should better preserved material become available, that the genus osperlioceras is represented 
among the small specimens ( $D=$ less than $25 \mathrm{~mm})$.

Grammoceras sensu Zato

Pl. l, figs. 11-14

Material: Twenty-one fragmentary specimens.

Description: These wretchedly preserved fragments all appear to be keeled. There is a considerable variety of costation that may be divided into five broad categories.

The first group, represented by four specimens, is characterized by a high whorl section, a prominent keel and ribs that are gently falcoid. The ribs are faint near the umbilical wall, strong on the flanks and faint again toward the keel. The ribs are rounded in cross section with narrow, sharp interspaces (F4-3-165, pl. 1, fig. 13).

The second group is characterized by a lower, probably more rounded, whorl section and ribs that are slightly sharper and more falcoid. The interspaces on these three specimens are wider than those of the first group (F4-3-123, pl. 1, fig. 14).

The third group, represented by twelve specimens, is similar to the second group in whorl shape (as far as preservation allows comparison) but differs in having sharper ribs that are less flexuous and more closely spaced (F4-4-17, pl. 1, fig. 12).

Specimen F5-1-0 (pl. 1, fig. 11) has gently convex 
flanks bearing very closely spaced, wirey, falcoid ribs. The fifth group, also represented by only one specimen, possesses flattened flanks bearing moderately sharp, low ribs that are gently flexuous (not figured).

Discussion: In the classification presented by Arkell, et al. (1957), the genus Pseudogrammoceras was synonomised with Grammoceras but such a step has been rejected by several workers (Donovan, 1958, p. 52; Dean, et al., 1961, p. 488). Grammoceras differs from Pseudogrammoceras in possessing sharp ribs with concave interspaces as opposed to flat, rounded ribs with angular interspaces (Donovan, 1958, p. 52) although the two styles are thought to intergrade. Pseudogrammoceras is probably represented by group one, which compares with some of the species figured by Buckman (1904, especially P. thrasu Buckman, p. 114, pl. 36, figs. 3 - 5). The second group is similar to the specimens of Grammoceras ? spp. of Imlay (1968, pl. 9, figs. 11 and 12 only) except that the ribbing is slightly less dense. Imlay (1968, p. C45) compared his specimens to Grammoceras (Pseudogrammoceras) regale Buckman (1904, fig. 138 on p. 146) although, when better preserved material becomes available, it might transpire that these specimens should be assigned to the similarly ribbed genus Podagrosites. This genus was created by Guex (1973, p. 8), separating all the 
species of Pseudogrammoceras characterized by a subquadrate whorl section and a tabulate, unicarinate, bisulcate venter. Group three is similar to Imlay's figured specimen of Grammoceras ? spp. that he compares with $G$. thouarsense (d'Orbigny) (1968, p. C45, pl. 9, fig. 10 only). Frebold, et al. (1969, pl. 1, figs. 16, 17) also figured similar specimens questionably compared with Grammoceras from British Columbia.

Specimen F5-1-0 is very similar to Grammoceras striatulum (Sowerby) as figured by Guex (1975, especially pl. 4, fig. 8) whereas specimen F4-4-1 is identical with a specimen of Grammoceras ? spp. from eastern Oregon that is questionably compared with G. striatulum (Imlay, 1968, p. C45, pl. 9, fig. 8 only).

Obviously, several species are represented in this group of ammonites referred to as Grammoceras s. 2 . but better preserved material must be collected before specific, or even generic, assignment can be made with confidence. Genus Dumortieria Haug, 1885 Dumortieria insignisimilis (Brauns)

$$
\text { P1. 1, fig. } 17
$$

non 1892 Catulloceras insigni-similis (Brauns); (C. insignisimile in text), Buckman, p. 278, pl. 39, figs. 12-14.

1923 Dumortieria insigni-similis Brauns; Ernst, p. 56, pl. 9, figs. 1-3.

? 1966 Catuloceras insignisimile (Brauns) (nomen nu(Zum); De Villalta and Rosell, pl. 1, fig. 6 . 
? 1967 Dumortieria insignisimilis n. supsp.; Géczy, p. 145, pl. 32, fig. 5 .

1967 Dumortieria insignisimizis (Brauns); Géczy, p. 144, pl. 31, fig. 6 .

Material: Five specimens.

Dimensions: Specimen no.

D Ud

$\mathrm{Rd}$

$\mathrm{u}$

*F 4-4-66

F 4-4-53

F 4-4-42

*F 4-4-24

F 4-4-14

23
c. 16.5
24.3
18.6
33.6

c. 10.3

18

45

* Distorted slightly

All specimens are flattened in the plane of coiling. Those marked with an asterisk have suffered slight compression at right angles to this plane.

Ribbing densities for various umbilical diameters are plotted in fig. 15.

Description: All the specimens assigned to this species are characterized by evolute coiling (u mean $=45.8$; $\sigma=2.48$ ) and a low rounded keel. Judging from the way in which the material is preserved, the whorl section was probably higher than wide.

The ribs are fairly sharp and rectiradiate, except near the venter where they swing abruptly forward to abut directly against the keel. The interspaces are wider than the ribs. 
Discussion: These specimens are considered conspecific with those figured by Ernst and Géczy (see synonomy above). There is a noticeable increase in the ribbing density passing up the succession which is evident in fig. 15. On this figure, ribbing densities for Dumortieria cf. $D$. dumortieri are also plotted to show the relationship between the two species in terms of ribbing. The last number in the specimen numbers denotes the relative stratigraphic position (see Appendix C).

Dumortieria insignisimilis differs from Dumortieria cf. D. exacta in being more evolute; less densely costate; the ribs being less wirey and lacking a mid-flank inflection. It differs from $D$. cf. D. dumortieri in being less densely costate and having a much more pronounced adoral inflection of the ventral ends of the ribs. D. raricostata differs in features of the ventral surface and in the ribbing which is much more projected in $D$. raricostata.

Dumortieria raricostata Géczy P1. 1, figs. 15-16

1967 Dumortieria stefaninii ? raricostata n. subsp.; Géczy, p. 142, pl. 31, fig. 8.

1968 Dumortieria raricostata Géczy; Setti, p. 332, pl. 32 , fig. 3 .

? 1968 Catulzoceras cf. C. dumortieri (Thiollière); Imlay, p. C46, pl. 9, fig. 5 only.

Material: Three specimens, two of them fragments. 


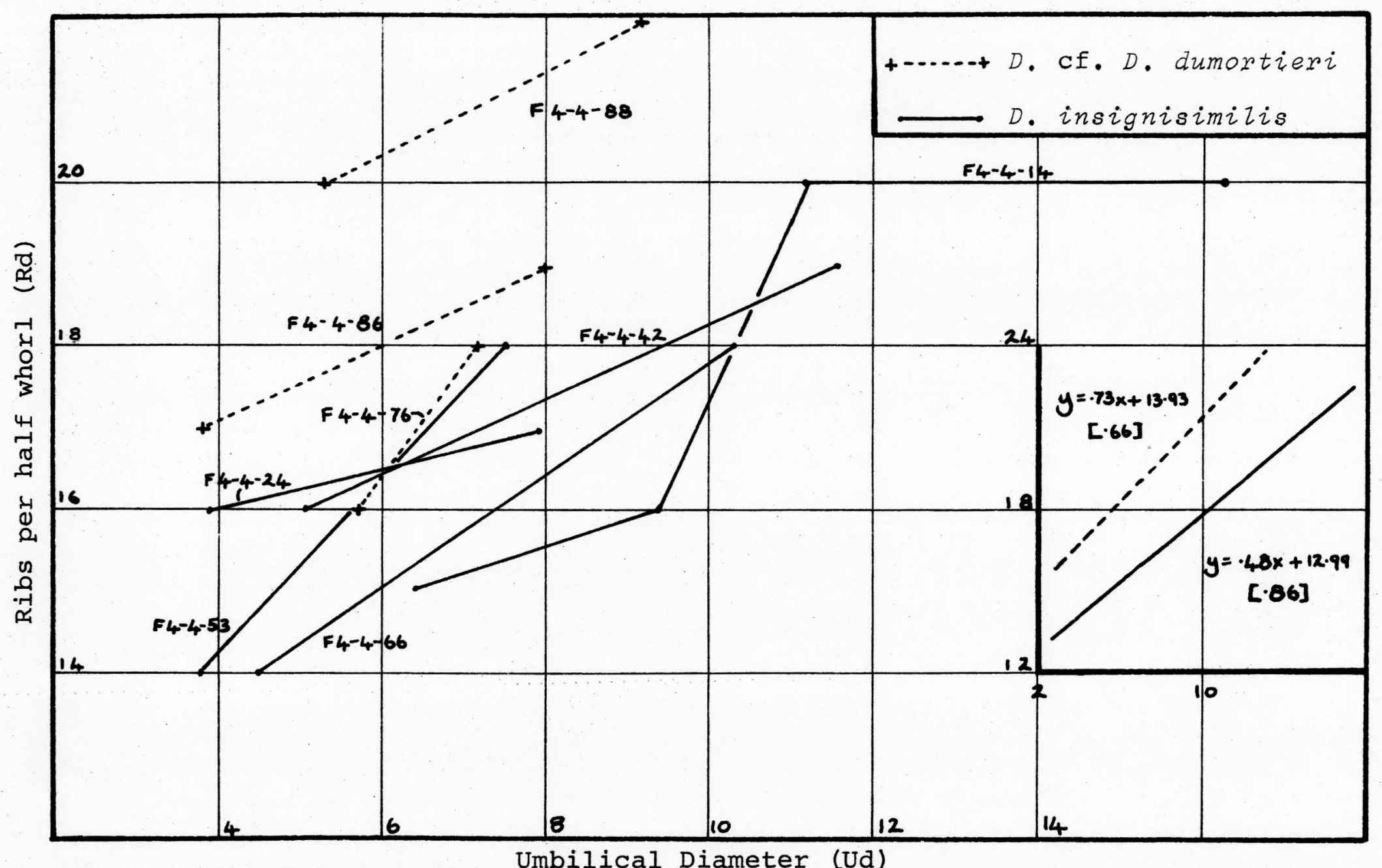

Figure 15. Rib densities for Dumortieria insignisimilis (Brauns) and Dumortieria cf. D. dumortieri (Thiolliere) - Section Four. 
Dimensions: Specimen no.

D

Ud

$\mathrm{Rd}$

$\mathrm{u}$
F 4-3-138
55.9
26.7
*23
48
* A collar is present; the last half whorl, excluding this collar, bears 25 ribs.

Description: These specimens are coiled in an evolute fashion with a wide, shallow umbilicus bordered by a low, rounded umbilical wall. Specimen F4-3-138 (pl. 1, fig. 15) bears a rounded keel approximately three-fourths of a millimeter in height.

The inner whorls bear sharp, rectiradiate to slightly prosiradiate ribs. At an umbilical diameter of approximately $20 \mathrm{~mm}$, a marked constriction is evident. Other constrictions may be present but the state of preservation makes this difficult to determine.

On the outer whorl, the ribs are seen to pass rursiradiately from the umbilical seam onto the lower flank from whence they follow an arcuate path, projecting forward onto the venter. The ribs are bold with the interspaces wider than the ribs. On the venter, the ribs do not abut directly against the keel but terminate very close to it.

Specimen F4-3-138 (and possibly specimen F4-3-128) bears a pronounced collar which is approximately $8 \mathrm{~mm}$ wide at its widest point. Faint growth lines are evident on the collar and the peristome is constricted. 
Discussion: Specimen F4-3-138 is a complete, mature individual that would be classified as a macroconch because of the presence of a collar and in accordance with the current ideas concerning sexual dimorphism in ammonites (see p. 30). The fact that it is smaller than other examples of this species that have been described to date ( $D$ mean $=74.7, \sigma=8.6)$ cannot be regarded as of great significance in a group possessing constrictions. The specimens described by setti, for example, show four or five constrictions on the outer whorls. These are thought to indicate segmental growth that is perhaps environmentally controlled.

These Oregon ammonites are assigned to this species because of the style of the ribbing; the presence of a keel that is separate from the ventral ends of the ribs, and the degree of involution ( $u$ mean for the specimens measured by Géczy and Setti $=52.5, \sigma=0.82)$. The name of the species signifies the density of the ribbing which is 26 per half whorl on the outer and penultimate whorls of the holotype (Géczy, p. 142) compared with 25 on F4-3-138. Géczy notes that the peristome of the holotype appears to be constricted obliquely (ibid., p. 143) in a similar manner to the oregon specimen but a collar is not evident. The specimen figured by Imlay (see synonomy above) and assigned by him to Catulzoceras cf. C. dumortieri is 
included here because the ribbing appears to be arcuate, similar to $D$. raricostata. In fact, the specimen in question looks very similar to the specimens described here before they were cleaned, using sand-blast equipment. Dumortieria cf. D. dumortieri (Thiollière)

$$
\text { Pl. 1, fig. } 19
$$

1874 Ammonites Dumortieri (Thiollière in Dumortier); figured by Roman, 1938, p. 105, pl. 9, fig. 96; and Arkell, et al., 1957, p. L262, fig. 296.

1892 Catulzoceras Dumortieri (Thiollière); Buckman, p. 277, pl. 39, figs. 6-9.

cf. 1964 CatulZoceras ? sp. indet.; Frebold, p. 16, pl. 7, figs. 5-9.

1967 Dumortieria dumortieri (Thiollière in Dumortier); Géczy, p. 137, pl. 30, fig. 8 .

cf. 1968 Catuzzoceras cf. C. dumortieri (Thiollière); Imlay, p. C46, pl. 9, figs. 2-4 only.

1968 Dumortieria dumortieri (Thiollière in Dumortier); Setti, p. 329, pl. 30, fig. 3, pl. 31, fig. 1.

1975 Catuzloceras dumortieri (Thiollière); Guex, p. 115, pl. 7, fig. 1 .

Material: Three specimens.

Dimensions: Specimen no. D Ud $\quad$ Rd $u$

$\begin{array}{llccc}\text { F4-4-88 } & \text { c. } 21 & 10 & -- & 48 \\ \text { F4-4-86 } & \text { c.16.5 } & 8 & 19 & 48 \\ \text { F4-4-76 } & 22.3 & 10.1 & -- & 45\end{array}$

Ribbing densities for various umbilical diameters are plotted in fig. 15 .

Description: These specimens are rather poorly preserved 
but one specimen, F4-4-76 (not figured), shows a very low keel. All the specimens are evolute with sharp dense ribbing that is almost straight except for a very slight projection onto the ventral surface. The umbilical wall is low and rounded.

Discussion: These specimens are much smaller than the examples figured from elsewhere and less evolute (u mean for those specimens measured by Géczy and setti is 57 , $\sigma=1.86, \mathrm{n}=7$; whereas $\mathrm{D}$ mean is 74$)$. The inclusion of this species under Dumortieria rather than Catulzoceras is discussed on page 23 and its distinguishing characteristics on page 83 (under $D$. insignisimizis).

It is possible that Dumortieria cf. D. dumortieri evolved from $D$. insignisimilis by a diminution of the keel and the ribs becoming more closely spaced and more rectiradiate. This seems reasonable on stratigraphic grounds. Fig. 15 illustrates that both species show a general trend of becoming densely costate up the succession but over a narrow stratigraphic interval (c. 10 feet).

Dumortieria cf. D. exacta Buckman

$$
\text { P1. 1, fig. } 18
$$

cf. 1892 Dumortieria subundulata (Branco); Buckman, p. 259, pl. 45, figs. 6-7.

cf. 1905 Dumortieria exacta Buckman; supplement, p. 187. 
Material: One specimen.

Dimensions: Specimen no.

D

Ud

Rd

$\mathrm{u}$

$$
\text { F } 4-4-38
$$

27.2

11

29

26

9.7

5.8

21

40

Description: A small, fairly evolute specimen flattened in the plane of coiling. The ventral surface, which is exposed on part of the outer whorl, bears a low keel bordered directly by the ventral ends of the ribs without the interruption of a sulcus (although the ribbing does fade slightly).

The earliest whorls are not visible but at c. $2.5 \mathrm{~mm}$ umbilical diameter, sharp, wiry, rectiradiate ribs are evident on the lower part of the whorl. These ribs are simple and equally spaced with the interspaces a little wider than the ribs. Ribbing densities for various diameters are shown above. At $c .5 \mathrm{~mm}$ umbilical diameter, the ribs are seen to pass prorsiradiately from the small, evenly rounded umbilical wall to the middle of the whorl flanks where they flex rursiradiately across the ventro-lateral shoulder before finally projecting adorally onto the ventral surface. At $8.5 \mathrm{~mm}$ umbilical diameter, this midflank inflection of the ribbing fades, the ribs becoming fairly straight except for the forward projection onto the venter which becomes slightly more pronounced adorally. The specimen is not complete so that the nature of 
the peristome cannot be determined. The suture line cannot be traced.

Discussion: This specimen compares most favorably with the ammonite figured by Buckman (1892, pl. 45, figs. 6-7). D. subundulata is a species noted for its variety of costation but Buckman (ibid., p. 262) describes a variant whose ribbing is identical with that shown by the specimen figured here. This variant is later elevated to the rank of species by Buckman and named $D$. exacta. The keel, whose presence indicates that this specimen should be assigned to the genus Dumortieria, is low with no bordering sulci, as with Buckman's specimen. The Oregon specimen differs from the English specimen in being slightly more involute $(\mathrm{u}=40 \mathrm{cf} . \mathrm{u}=43$ ) and having what appears to be a higher whorl section in the outer whorl. The latter feature could be due to post-mortem deformation.

There are certain resemblences between this specimen and D. pseudoradiosa as figured by Guex (1975, pl. 7, fig. 7) and also with a specimen of D. pseudoradiosa collected from the French Jura and now held in the University of California Museum of Paleontology. These specimens do not show the inflection of the ribbing on the mid-flank, however. This mid-flank inflection is acharacteristic common to the genus Grammoceras which Buckman notes as being difficult to separate from Dumortieria in some instances 
(1892, p. 162). The short forward projection of the ribs onto the ventral surface in the case of specimen F4-4-38 and the straightness of the ribbing on the outer half whorl is enough to suggest an assignment to Dumortieria rather than Grammoceras.

Dumortieria ? cf. D. pusilza Jaworski

$$
\text { P1. 1, figs. 20-22 }
$$

cf. 1926 Dumortieria pusizla Jaworski; p. 213, pl. 4, figs. $10 a, b, 11$.

1968 Dumortieria ? cf. D. pusizla Jaworski; Imlay, p. C45, pl. 9, figs. 1, 6, 7.

Material: Seventy-five specimens.

Dimensions: Specimen no.

D

Ud

Rd

$\mathrm{u}$

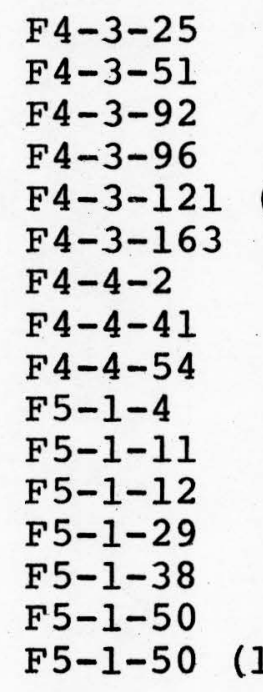

$$
\text { c. } 27
$$

33.1

c. 14

c. 12.1

$-$

20.3

10.8

13

18.7

(3)

c. 19

8.1

8.5

9

37

c. $30^{.8}$

19.6

12.9

13

c. 17

14

15

28

c. 22

16.7

c. 12.9

c. 19.5

c. 19

(10)

c. 15

8.1

$--$

43

45

48

57

41

6.2

$--$

41

12.5

c. 11

45

10.6

12

48

7.3

44

5.8

45

12

6.5

c. 6.5

11

62

c. 11

c. 13

34

43

Description: All the ammonites included here are evolute (u mean for 16 specimens $=46.13 ; \sigma=6.94$ ) and fairly small ( $\mathrm{D}$ mean $=21.41$ ). The venter bears a keel bordered on each side by smooth areas. The umbilical wall is low, 
steep and rounds abruptly into the flattened flanks. The nucleus of each individual is smooth to a maximum umbilical diameter of approximately $7 \mathrm{~mm}$. Smooth juveniles are included in the collection. At diameters greater than $7 \mathrm{~mm}$. these ammonites bear rounded, widely spaced ribs, that are rectiradiate to slightly rursiradiate and swing feebly forward high on the flanks. On internal molds the ribs are much sharper. The number of ribs per half whorl increases very slowly with growth. This is shown in fig. 16 where an indication of the development of the smooth stage is also given.

Discussion: To date, this species had only been collected from one locality in North America, from the west bank of Wickiup Creek just to the northeast of the Izee area. It was first identified in communications from the U. S. Geological Survey as Arnioceras which everywhere else in the world is restricted to the Sinemurian Stage (Imlay, 1968, p. C45). Later collecting indicated its association with Toarcian fossils and this is confirmed here. Dr. Imlay of the United States Geological Survey suggested a comparison with $D$. pusilza from Argentina, described by Jaworski, which differs from European examples of Dumortieria in possessing a smooth nucleus (Imlay, oral communication, 1975).

Some of the individuals collected during this study compare favorably with one of the specimens figured by Imlay 


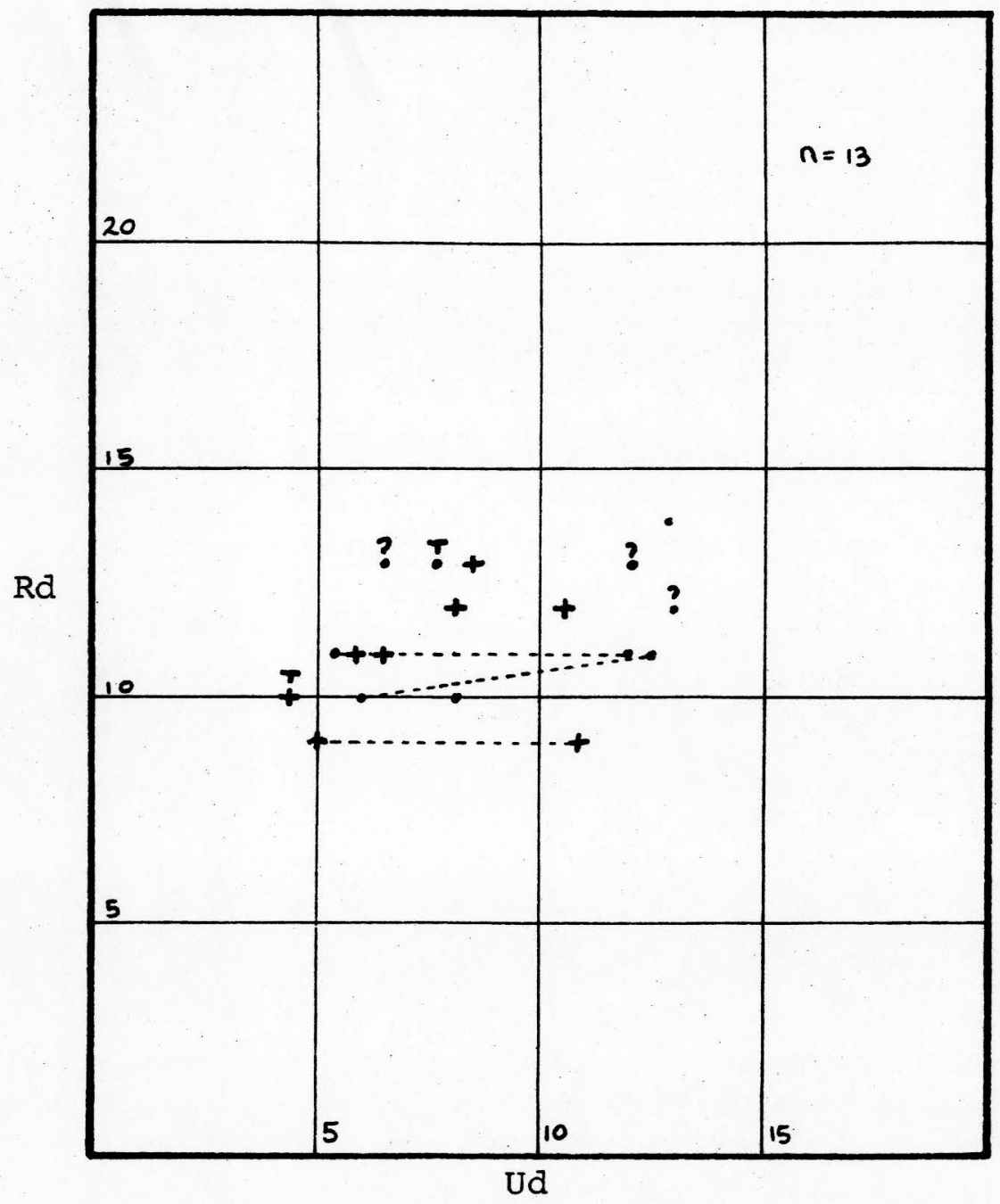

Key:

Umbilical diameter

- at which smooth stage is lost, greater than or equal to $5 \mathrm{~mm}$.

Umbilical diameter

+ at which smooth stage is lost, less than

$5 \mathrm{~mm}$.

: Type specimens

I Dumortieria pusizza

+ Jaworski.

? Nucleus obscured.

Figure 16. Dumortieria ? cf. D. pusizla Jaworski: variation of ribbing density during ontogeny. 
ibid., pl. 9, fig. 7) and are probably conspecific with D. pusilZa. Specimen F5-1-4, figured here (pl. 1, fig. 20), is almost identical with one of the types figured by Jaworski (1926, pl. 4, fig. 10a, b). Other specimens, however, (see pl. 1, fig. 21) are more evolute and possess wider ribs comparing with Imlay's pl. 9, fig. 6 .

A few other small ammonites occurring fairly high in Section 4 are included here but differ from the rest of the specimens in possessing much sharper ribs (see pl. 1, fig. 22). This may be due to preservation, as mentioned above.

Genus Tmetoceras Buckman, 1892

Tmetoceras scissum (Benecke)

$$
\text { Pl. 2, figs. } 1-2
$$

1865 Ammonites scissus Benecke; figured by Roman, 1938, p. 105, pl. 9, fig. 97 and Arkell, 1957, p. L262, fig. 297.

1878 ? Cosmoceras Regleyi Thiollière; Gottsche, p. 16, fig. 3 .

1892 Tmetoceras scissum (Benecke); Buckman, p. 273, pl. 48, fig. 1-9.

1933 Tmetoceras scissum (Benecke); Arkell, pl. 33, fig. 4 .

1951 Tmetoceras regleyi (Thiollière) Dumortier; Frebold, p. 18, pl. 15, fig. 1-4.

1954 a Tmetoceras recticostatum Sato; Sato, p. 118, pl. 13, figs. 1-18.

1955 Tmetoceras sp.; Imlay, p. 89, pl. 12, figs. 7-10.

1955 Tmetoceras scissum (Benecke); Maubeuge, p. 17, pl. 2, figs. la-c. 
1964 a Tmetoceras (Tmetoceras) scissum (Benecke); Westermann, p. 428 , pl. 72, figs. la, b, $2 a, b$.

1964 Tmetoceras regleyi Dumortier; Komalarjun and Sato, p. 157, pl. 6, figs. 10-12, 14, 15 .

1969 Tmetoceras cf. T. scissum (Benecke); Frebold, Tipper and Coates, p. 21, pl. 1, figs. 1-5.

1972 Tmetoceras scissum (Benecke); Westermann and Riccardi, p. 22, pl. 1, figs. 1-5.

1973 Tmetoceras scissum (Benecke); Imlay, pl. 2, figs. $1-6$.

Material: Ninety-four specimens.

Dimensions: Fig. 17 is a scatter diagram showing the density of ribbing at various ontogenetic stages in comparison with the holotype.

Description: Most of the specimens are fragmentary and all are flattened in the plane of coiling to some degree. Suitably preserved specimens show that this species was evolute with a high umbilical wall and strongly convex flanks. The rectiradiate ribbing is characteristically sharp, dense and high, terminating ventrally in small spines which flank a shallow, mid-ventral groove.

Discussion: The genus has been discussed at length in the section dealing with paleontology (p. 21). Westermann (1964a, p. 428-435) has made a detailed study of T. scissum which has a world wide range and is restricted to the early Bajocian, with rare or questionable occurrences 


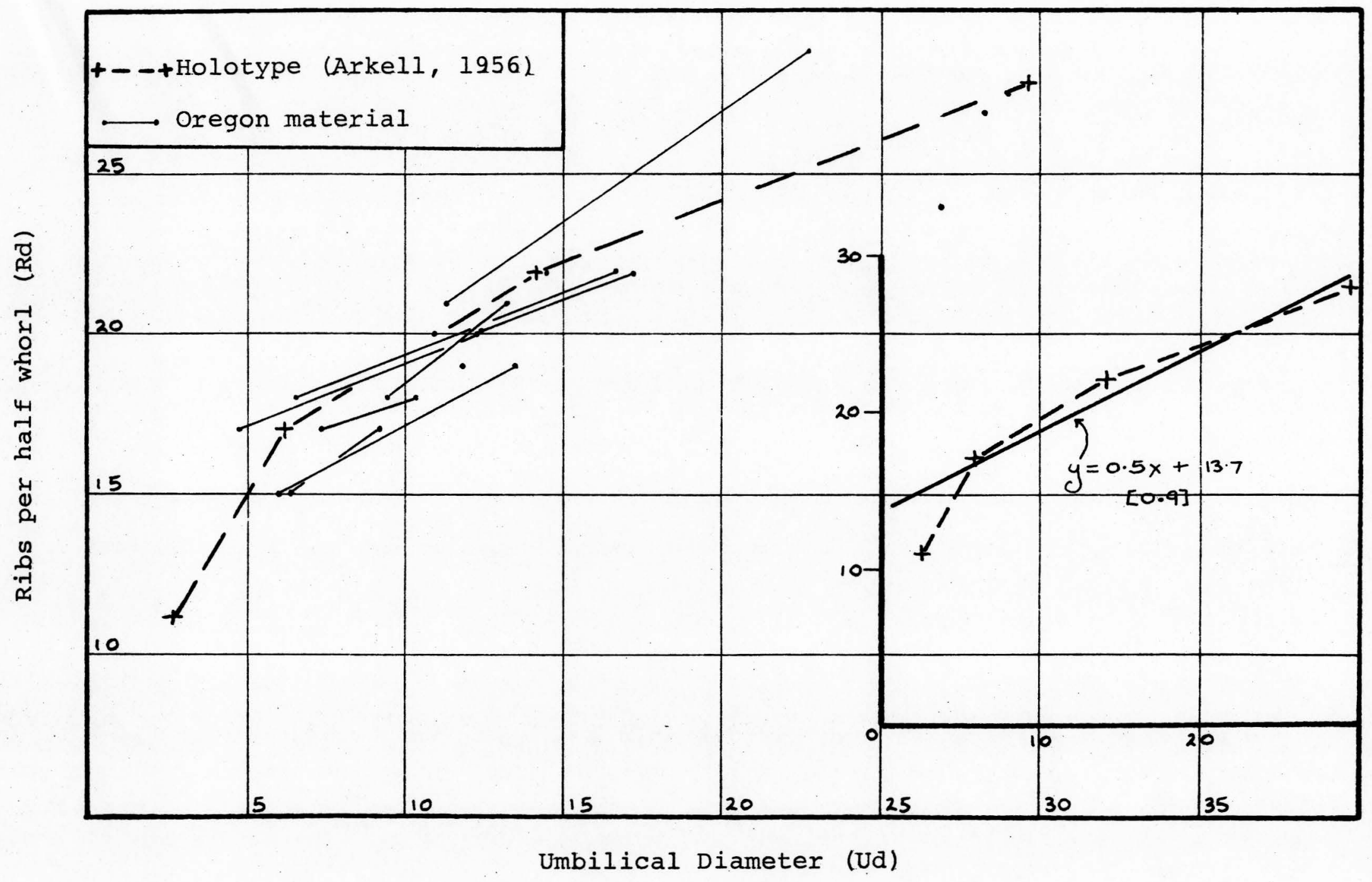

Figure 17. Tmetoceras scissum (Benecke): variation of ribbing density during ontogeny. ดั 
in the uppermost Toarcian. T, scissum can be differentiated from Dumortieria insignisimilis (Brauns) by the straightness of its ribbing and from $D$. cf. D. dumortieri (Thiolliere) by the absence of a keel and by its ventrally swollen ribs. Family HAMMATOCERATIDAE Buckman, 1887

Genus Hammatoceras Hyatt, 1867

Hammatoceras speciosum Janensch

P1. 2, fig. 4

1975 Hammatoceras speciosum Janensch; Guex, p. 111, pl. 9, fig. 8; pl. 10, figs. 1, 3 .

Material: Two specimens.

Dimensions: Specimen no. D Ud sRd Td u

$\begin{array}{lrrrrr}\text { F 4-4-39 } & 35.2 & 10 & \text { c. } 24 & \text { c. } 8 & 28 \\ \text { F 4-3-137 } & \text { c. } 40 & \text { c. } 12 & -- & c .10 & 30\end{array}$

Description: Specimen F4-4-39 (pl. 2, fig. 4) is crushed in the plane of coiling with only a small part of the ventral surface visible. Specimen F4-3-137 (not figured) is an external mold. The specimens are very involute with the last incomplete whorl egressing and inflating slightly. The whorl height of the outermost whorl (from umbilical seam to venter) at the point at which the diameter was measured on F4-4-39 is $c .16 .5 \mathrm{~mm}$. i.e. 47 percent of the diameter. This is exaggerated slightly by crushing but the whorl section was probably considerably higher than wide. The innermost whorls show a steep, evenly rounded 
umbilical wall with swollen primary ribs arising low on the wall and becoming bullate very close to the umbilicus. Where egression of the last whorl has occured, the last part of the penultimate whorl shows that each bulla gives rise to two wide, sub-parallel, secondary ribs. At $6 \mathrm{~mm}$. umbilical diameter, the tubercles become sharper and progressively less bullate. The tubercles are always close to the umbilical margin. On the outer whorl there are approximately three secondary ribs per primary, the third rib arising by intercalation or perhaps trifurcation (poor preservation obscures this). The secondaries are dense, rectiradiate to slightly prorsiradiate and are seen to pass onto what is preserved of the ventral surface.

The suture line could not be traced.

Discussion: These specimens are almost identical with the specimen figured by Guex from southern France (1975, pl. 9, fig. 8 where $D=35, \mathrm{sRd}=22, \mathrm{Td}=8$ and $\mathrm{u}=27$, measured from the plate) as far as preservation allows comparison. H. speciosum is similar to H. praefalzax Monestier, but the latter species is characterized by an absence of tubercles on the nucleate whorls and the early part of the body chamber (Monestier, 1921, p. 37).

Hammatoceras spp. P1. 2, figs. 3,5

1968 Haugia spp.; Imlay, p. C46, pl. 9, figs. 14, $15,17,18$. 
Material: Thirteen fragments.

Description: All the specimens assigned to this genus are wretchedly preserved, flattened fragments.

One specimen, F4-4-25 (pl. 2, fig. 3), is a whorl fragment with a high whorl section and a not very prominent keel. Fairly sharp, straight, closely spaced ribs arise by bifurcation from sharp tubercles low on the flanks. On the other specimens the ribs are less sharp but this could be a result of weathering. On specimen F4-4-28 (pl. 2, fig. 5), the ribs are slightly flexuous. This specimen also shows its ventral surface where a low, rounded keel is seen to be bordered almost directly by the ventral ends of the ribs.

Discussion: These specimens are considered to be probably congeneric with the specimens figured by Imlay (ibid.). They are tentatively assigned to Hammatoceras rather than Haugia because the latter genus is characterized by a tall, massive keel (Arkell, et al., 1957, p. L266) whereas Hammatoceras has a much lower, rounded keel as found on the eastern Oregon ammonites. However, in other respects, these genera are fairly similar. The variation in the strength of the ribbing described by Imlay (1968, p. C46) is also evident in these specimens and is reminiscent of the style of ribbing displayed by various Toarcian species figured by Merla (1933, pls. 1 and 2). Much better preserved specimens 
are needed, however, before reliable specific determinations can be made.

\author{
Genus PZanammatoceras Buckman, 1922 \\ PZanammatoceras ? spp. \\ P1. 2, figs. 6-9
}

Material: Seventeen specimens.

Description: All the specimens are poorly preserved, flattened fragments. The group as a whole is characterized by being large, having a high whorl section and by the presence of a fairly high keel.

One style of ornamentation consists of strong, swollen primaries that pass prorsiradiately across the lower half of the flank at which point two equally strong secondaries arise by furcation. The secondaries do not fade ventrally but appear to abut directly against the keel. All the ribs are wide, rounded and separated by relatively sharp interspaces. At furcation points on some specimens, pronounced, blunt tubercles are evident. This group is characterized by the figured specimens F2-19-67 and F2-19-93 (pl. 2, figs. 9, 7) .

Other specimens show much finer, denser ribbing (F2-12-20, pl. 2, fig. 8) while in others, the furcation points are sharply bullate and the secondaries divergent as opposed to parallel or sub-parallel (F2-19-43, pl.2, fig. 6). 
Discussion: Planammatoceras was also questionably recognized from eastern Oregon by Imlay (1973, p. 61, pl. 24, figs. 2, 3; pl. 27, figs. 2, 3). The taxonomic position of Planammatoceras is not settled at present. Imlay points out that the presence of tubercles does not bar an assignment to Planammatoceras (1973, p. 61) because Parammatoceras rugatum Buckman (1925, pl. 578) and Hammatoceras planinsigne Vacek (see Géczy, 1966, pl. 11, figs. 1-3) both possess swellings or tubercles and are assigned by Arkell to PZanammatoceras (1956, p. 177; Arkell, et al., 1957, p. L267). However, PZanammatoceras is considered a synonym of Hammatoceras by some workers (Géczy, 1966, p. 31). Those forms with swollen primaries or low, blunt tubercles compare with Hammatoceras planinsigne Vacek (Géczy, pl. 1l, fig. 2), Parammatoceras rugatum Buckman (1925, pl. 578, figs. 1, 2) and the inner whorls of $P$. obtectum Buckman (1925, pl. 555) except that the ribbing is gently flexuous in the latter. Those forms with finer ribbing and sharply bullate furcation points compare with PZanammatoceras sp. cf. P. Kitakamiense (Sato) (Hirano, 1973, p. 46, pl. 9, figs. 7a, b) and Hammatoceras chibai Yokoyama (Sato, 1954b, p. 94, pl. 8, fig: 6) as far as preservation allows comparison.

Family SONNINIIDAE Buckman, 1892 Genus Sonninia Bayle, 1879 
Sonninia cf. S. nodatipinguis (Buckman)

$$
\text { P1. 3, fig. } 8
$$

cf. 1923 Stiphromorphites nodatipinguis Buckman; pl. 398

1973 Sonninia cf. S. nodatipinguis (Buckman); Imlay, p. 62, pl. 13, figs. 1-4.

Material: Three specimens.

Dimensions: Specimen no.

$\begin{array}{crrr}\mathrm{D} & \mathrm{Ud} & \mathrm{Rd} & \mathrm{u} \\ { }^{1} 70 & \text { c. } 25 & 10 & 36 \\ & 10 & 9 & \\ & \text { c. } 8 & c .14 & \end{array}$

*2F1-23-3

$$
\text { F5-5-199 }
$$

c. 8

c. 14

* 1 Estimated

*2 Compressed at right angles to the plane of coiling

Description: One specimen is a fragment of a whorl, the others incomplete individuals, one of which is distorted. All are internal molds with a considerable amount of shell material adhering.

The coiling is evolute and the venter bears a high, somewhat rounded keel. The whorl section was probably compressed. The umbilical wall is fairly low on the inner whorls, rounding gently into the convex flanks, but becoming steeper at umbilical diameters greater than $15 \mathrm{~mm}$.

The innermost whorls bear strong, swollen ribs that arise at the base of the umbilical wall and pass rectiradiately across the flanks. The outer whorls bear ribs that are separated by wider interspaces. The ribs are 
strongest on the lower part of the flank and some fade and disappear by the middle or upper third of the flank. Those that do not disappear, project slightly onto the ventral surface.

Discussion: These specimens compare with specimens collected from the Snowshoe Formation near Seneca and figured by Imlay (20c. cit.). As noted by Imlay, they are similar to $S$. tuxedniensis Imlay but differ in having ribs that are stronger on the lower part of the flank.

$$
\text { Sonninia sp. }
$$

Material: One specimen.

Dimensions: Specimen no. D Ud Rd $u$ Wh $\mathrm{Wb}$

$$
\begin{array}{rrrrrrr}
\text { F1-22-22 } & c .125 & c .45 & -- & 36 & c .44 & --
\end{array}
$$

Description: Specimen F1-22-22 is incomplete and has been crushed in some places. The inner whorls are not visible, mainly due to oyster encrustation.

The shell is a large planulate with a compressed, ovate whorl section. The umbilical wall is steep, rounding rapidly into the flattened flanks. A high (c. $3 \mathrm{~mm}$.$) ,$ flat-sided keel is present.

The earliest visible whorl bears strong, widely spaced, simple, rectiradiate ribs that are strongest at 
mid-flank. The ribs become more closely spaced and project slightly onto the venter where they fade, well before reaching the keel. The ribbing becomes obsolete on the last part of the outer whorl which is smooth except for fine, flexuous striations.

Discussion: The costate whorls of this specimen appear to be identical with the holotype of Sonninia alsatica (Haug) as figured by Westermann and Riccardi (1972, p. 49, fig. 9) who also figure specimens of this species collected from Sauzei Zone age deposits in the Andes (op. cit., pl. 10, figs. 1-7). The Oregon specimen is much larger, however, and differs in developing a smooth outer whorl (a characteristic of the genus Sonninia) with flexuous striae similar to S. nodatipinguis (Buckman) (1923, pl. 398) and to a lesser extent, S. tuxedniensis Imlay (1964b, pl. 2, figs. 5-10). Subgenus Papizliceras Buckman, 1920

Sonninia (Papizziceras) spp.

$$
\text { P1. 3, figs. 3-4, } 6
$$

Material: Eight specimens.

Description: This subgenus is represented by fragments of internal molds with some shell material adhering. One group, represented by three specimens, is fairly involute, with a narrow umbilicus bordered by a very low, vertical umbilical wall. The shell is compressed and a 
low keel is present. The ribbing is very weak, arises from the umbilical shoulder, passes flexuously across the flank, becomes swollen or tuberculate at mid-flank and projects slightly onto the venter (specimen F3-17-29 and F3-17-80, pl. 3, figs. 3, 6) .

Another group, represented by two specimens, is slightly more evolute and differs also in the ribs being stronger and lower on the flank, in the tubercles being stronger and positioned slightly below mid-flank, and in the ribs fading on the upper part of the flank. One specimen is septate (specimen F3-30-243, pl. 3, fig. 4).

One small fragment of a whorl (F3-30-319) is distinct from the other specimens in possessing large, blunt tubercles whereas another, large, flattened specimen (F2-52-7, $\mathrm{D}=c .100, \mathrm{Ud}=c .30$ ) bears rectiradiate ribs on its outer whorl that show incipient swellings at the mid-flank position.

Discussion: These specimens are assigned to the subgenus Papilziceras on the basis of the tubercles or papillae developed, or incipiently developed, at or near the midflank position. Whether this is an adequate characteristic to separate the subgenus from Sonninia $s . s$. has been discussed by Westermann and Riccardi (1972, p. 73-77) and Morton (1975, p. 45).

The specimens of the first group described here 
resemble the inner whorls of $S$. (P.) cf. $S$. (P.) juramontana (Crickmay) figured by Imlay (1973, pl. 27, fig. 1). However, the holotype on which this species is based (Crickmay, 1933, p. 911, pl. 31 l is a poorly preserved fragment and consequently, the species has been declared nomen dubium by Westermann and Riccardi (1972, p. 76).

The other specimens are too poorly preserved to allow specific comparisons.

$$
\begin{aligned}
& \text { Subgenus Euhoplo ceras Buckman, } 1913 \\
& \text { So nninia (Euhoploceras) spp. } \\
& \text { Pl. 3, fig. } 2
\end{aligned}
$$

Material: Two specimens.

Description: Both specimens are flattened whorl fragments. One of the ammonites (A. 0756) was collected from section 3 and donated by $\mathrm{Mr}$. Taylor. It is a large whorl fragment characterized by very faint, broad ribs at the base of the flanks passing into very large, widely spaced tubercles, one of which bears an elongate spine. The upper part of the whorl is not visible.

The other fragment, representing less than oneeighth of a whorl, bears strong, closely spaced ribs that are sharp in outline and separated by broadly rounded interspaces. Two of the ribs are fairly straight, the 
others flex slightly, just above the mid-flank position.

Discussion: Specimen A. 0756 has been compared by Taylor (personal communication, 1975). with some of the specimens figured by Imlay and referred to $S$. (E.) crassispinata Buckman (Imlay, 1973, pl. 22, figs. 1, 2; pl. 23, figs. 2-4; pl. 24, figs. 1, 4; pl. 25, figs. 17-19 only). Taylor separates these specimens, referring them to a new, soon to be described species, Euhoploceras westi, which differs from Imlay's specimens in possessing much coarser and more widely spaced spines on the outer whorl as well as in other respects not evident in the specimen presently under discussion (Taylor, 1976).

The other fragment bears ribbing whose strength and style compares with some specimens of $S$. (E.) adicra (Waagen) (Imlay, 1973, especially pl. 14, figs. 1, 5; pl. 15, fig. 5; pl. 16, fig. 1) but poor preservation does not warrant specific designation.

Genus Witchel Zia Buckman, 1889

Witchel lia connata (Buckman)

Pl. 2, fig. 10

1927 Zugella connata Buckman; pl. 750.

cf. 1951 Witchellia (Zugella) aff. connata Buckman; Maubeuge, p. 31, pl. 16, fig. 4.

1973 Witchellia connata (Buckman); Imlay, p. 69, pl. 21, figs. 1-7, 10, 11; (non pl. 20, fig. 4). 
Material: Eleven specimens.

Dimensions: Specimen no.

D Ud Rd u

$\begin{array}{llccc}\text { *F } 3-30-8 & 45 & -- & -- & -- \\ F 3-30-31 & 22 & c .6 .5 & 23 & 30 \\ F 3-30-33 & 22 & 8.5 & 21 & 39 \\ \text { F } 3-30-131 & 18 & 6 & -- & 33\end{array}$

* Distorted slightly

Description: Half of the specimens representing this species are flattened internal molds, mostly fragmentary, the others being external molds.

This species is characterized by its moderately involute coiling ( $u$ for the holotype measured from the plate $=32$ at $D=56$ ) and a low keel bordered by furrows. The umbilical wall is low and rounds evenly into the flattened flanks of the compressed whorls.

The ribs are thin and sharp, separated by wider interspaces. They arise singly or in pairs from the umbilical shoulder, are generally rectiradiate and slightly flexuous on the flank and project onto the venter, terminating near the ventral furrows.

Discussion: As noted by Imlay (1963, p. 69), these oregon specimens are virtually identical with the holotype of W. connata Buckman (1927, pl. 750) collected from Sherborne, Dorset, England.

$$
\begin{aligned}
& \text { Witchel Zia spp. } \\
& \text { Pl. 2, fig. } 11
\end{aligned}
$$


Material: Three specimens.

Description: Two of the specimens (from Locality A) are internal molds with some shell material adhering. They are characterized by being fairly involute, compressed, with steep rounded umbilical walls, flattened flanks and a broad venter bearing a high keel bordered by shallow sulci. The simple (?) ribs arise near the umbilical region, are flexuous and rectiradiate to slightly prorsiradiate on the flanks and fade on the ventro-lateral shoulder. The ribs are fairly strong on the earlier whorls but at umbilical diameters greater than approximately $10 \mathrm{~mm}$. they fade, becoming striate or effaced.

The other, poorly preserved specimen is more involute, more inflated and the bisulcate, unicarinate venter is less evident.

Discussion: These specimens are places in the genus Witchellia rather than Dorsetensia because they are small, involute forms and yet their venters are tabulate rather than fastigate. Also, the keel is laterally sulcate.

Subgenus Latiwitchellia Imlay, 1973 Witchellia (Latiwitchelzia) evoluta Imlay P1. 2, fig. 12

cf. 1964b Sonninia ? n. sp. indet.; Imlay, p. B33, figs. 10, 11 only.

1973 Witchellia (Latiwitchellia) evoluta Imlay; p. 70, pls. 31-33. 
Material: Four specimens.

Description: Most of the material consists of flattened internal or external molds with no shell material adhering but specimen $\mathrm{F} 3-30-68$ (p1. 2, fig. 12) retains some cross-sectional shape.

These specimens are characterized by their evolute coiling with a wide umbilicus bordered by a fairly high, rounded umbilical wall. The whorl shape seems to have been low, somewhat compressed, with gently rounded to flat flanks that round evenly into the venter. The venter is not well preserved on any of the specimens but specimens F3-17-93 and F3-30-68 do show a keel that is bordered by furrows.

The innermost whorls bear very broad, rounded, simple ribs that are separated by much narrower and sharper interspaces. The ribs trend rectiradiately across the lower part of the flanks and bear nodes evident just below the umbilical seam. Specimen F3-30-68 bears strong ribs, some of which are swollen at the point of maximum curvature of the flank. Secondary ribs arise periodically by intercalation just above mid-flank and all the ribs project to some degree, sometimes strongly, onto the ventral surface where they terminate abruptly against the sulci. On other whorl fragments of a comparable size, the swollen ribs bifurcate at or just below the middle of the flank. 
The first lateral lobe of the suture line is much longer than the second lateral lobe.

Discussion: These specimens appear to be identical with the variants of $W$. (L.) evoluta that display ribbing of moderate strength (Imlay, op. cit., p. 71, pl. 32).

Genus Dorsetensia Buckman, 1892

Dorsetensia edouardiana (d'orbigny)

$$
\text { P1. 4, fig. } 1
$$

1892 Dorsetensia edouardiana (d'orbigny); Buckman, p. 304, pl. 52, figs. 8-24.

1892 Dorsetensia sp. A; Buckman, p. 304, pl. 52, figs. 1-3.

1892 Dorsetensia sp. B; Buckman, p. 304, pl. 52, figs. 4-7.

1957 Dorsetensia edouardiana (d'Orbigny); Arkell, et $a$., p. L270, fig. 31l, 10a, b.

1968 Dorsetensia edouardiana (d'Orbigny); Huf, p. 72 , pl. 7, figs. 6-7; pl. 8, figs. 1-4; pl. 9 , fig. 1 .

Material: One specimen.

Description: This specimen consists of part of an internal mold (external mold also available) that has been distorted and compressed. The coiling is fairly evolute with a wide umbilicus bordered by a step-like umbilical wall. The whorl section was probably compressed with flattened flanks and a venter bearing a high keel. 
The strong, sharp ribs arise singly from the umbilical wall, pass rectiradiately across the flank and project onto the venter. Some of the ribs flex slightly just below the middle of the flank. Adorally, the ribs appear to become rursiradiate but this may be due to distortion.

Discussion: As far as preservation allows comparison, this specimen appears to be identical with $D$. edo uardiana. Even the rursiradiate ribbing on the outer part of the last whorl is identical with the ribbing on a specimen figured by Buckman ( $p p$. cit., pl. 52, fig. 18) .

Dorsetensia oregonensis Imlay

Pl. 4, figs. 2-3

1973 Dorsetensia oregonensis Imlay; p. 72, pl. 29, figs. $1-4$.

Material: Eight specimens.

Dimensions: Specimen no.

D

Ud

$\operatorname{Rd}$

u

*F3-30-346 (2)
$F 3-30-362$
$F 3-31-53$
*F3-31-84
$F 3-31-147$
*F3-31-224

39

12

c. 15

31

--

7.2

36

9.2

8
13

--

*F3-31-224

$* 175$

11.6

12

18.8

9

c. 17

32

60

19

16

31

* Slightly distorted

*1 Estimated

Description: The specimens representing this species are 
all internal molds, some with a great deal of thick, original shell material adhering.

The coiling is fairly evolute with a wide, shallow umbilicus bordered by a steep (becoming vertical adorally) umbilical wall that rounds very abruptly into the flattened flanks. The whorl section is compressed, higher than wide with flattened flanks and a venter that bears a simple, usually low keel.

The inner whorls are ornamented with simple, fairly wide, rectiradiate ribs that become slightly weaker ventrally and slightly projected. The ribbing becomes weaker adorally

Discussion: These specimens are considered conspecific with the common $D$. oregonensis Imlay. This species differs from $D$. edouardiana (d'Orbigny) in the nature and strength of the ribbing, and from D. romani (Oppel) in being more evolute and bearing stronger ribs.

Dorsetensia pinguis (Roemer)

P1. 4, figs. 5-6

1939 Sonninia pinguis (Roemer); Hiltermann, p. 164, pl. 11, figs. 8-12 only.

1968 Sonninia (Poecilomorphus) pinguis pinguis (Roemer); Huf, p. 54, pl. 4, figs. 7-12; pl. 5, figs. $1-8$.

1972 Dorsetensia pinguis (Roemer); Morton, p. 510, pl. 105, figs. 1-10, 17-20 (non figs. 11, 12).

Material: Nine specimens. 
Dimensions: Specimen no.

D Ud Rd u

$\begin{array}{cllll}\text { F3-30-389 } & 20 & 6.5 & c .12 & 33 \\ \text { F3-31-27 } & 20 & 5.2 & c .10 & 26 \\ \text { *F3-31-82 } & 34 & 9.5 & 12 & 28 \\ \text { F3-31-86 } & 27 & 9 & 11 & 33 \\ \text { F5 4-68 } & 29 & 6.8 & 16 & 23 \\ \text { F5 5-2 } & 23 & 7.4 & 14 & 32 \\ \text { F5-5-11 (1) } & 18 & 7.2 & -- & 40\end{array}$

* Slightly distorted

Description: Moderately evolute, small, with steep umbilical wall passing into a rounded to sub-angular umbilical shoulder. Whorls slightly compressed, with flattened to gently convex flanks. The original shape of the venter is difficult to determine because of crushing but a fairly prominent keel is present.

The ornamentation consists of broad to fairly fine ribs that arise mostly in pairs from the umbilical shoulder and trend radially across the flanks. Some of the ribs are slightly flexuous.

Discussion: These specimens are all considered to fall within the range of variation of that group of ammonites now referred to as $D$. pinguis, as recently discussed by Morton (op. cit., p. 511). Some of the specimens, e.g. F5-5-2, appear to be identical with Morton's material (especially pl. 105, figs. 5, 6) whereas others, e.g. F3-31-27, compare most favorably with Huf's material (especially pl. 4, figs. 9a, b) . 
Do rsetensia romani (Oppel)

$$
\text { Pl. 4, figs. 4, 7-8 }
$$

1892 Do rsetensia compl anata Buckman; p. 306, pl. 53, figs. 1-10; pl. 54, figs. 1-2.

1935 Dorsetensia complanata Buckman; Dorn, p. 98, pl. 9, fig. 4; pl. 10, fig. 5 .

1935 Dorsetensia romani Oppel; Dorn, p. 100, pl. 9, fig. 5; pl. 11, fig. 4; pl. 13, fig. 2 .

1951 Dorsetensia complanata Buckman; Maubeuge, p. 40, pl. 1, fig. 2a-c; pl. 14, fig. 3 .

1968 Dorsetensia romani romani (Oppel); Huf, p. 86, pl. 13, fig. 6; pls. 14-27; pl. 28, figs. 1-2.

1972 Dorsetensia romani (oppel); Morton, p. 508, p1. 103, figs. 3-8; pl. 104, figs. 3-6.

1972 Dorsetensia romani (Oppel); Westermann and Riccardi, p. 104, pl. 30, figs. 6-7.

Material: Seven specimens.

Dimensions: specimen no.

D

Ud

$\mathrm{Rd}$

u

\begin{tabular}{|c|c|c|c|}
\hline *F $3-30-361$ (1) & 17.6 & 5.7 & 14 \\
\hline F $3-30-361$ (2) & & 12.9 & - \\
\hline *F $3-31-98$ (1) & $c .19$ & 6.2 & 13 \\
\hline *F3-31-98 (2) & c. 22 & 6.3 & -- \\
\hline *F3-31-108 & 22 & 7 & -- \\
\hline
\end{tabular}

Description: Moderately involute, highly compressed forms. The whorls are much higher than wide with flattened flanks and an acutely fastigate venter bearing a low keel. The umbilical wall is vertical, the umbilical angle sharp. The inner whorls bear broad, undulating or crinkled 
ribs that trend rectiradiately or prorsiradiately on the flanks and project slightly onto the venter, where they fade. The ribbing becomes obsolete at umbilical diameters greater than about $7 \mathrm{~mm}$, the outer whorls being smooth except for distant undulations confined to the lower part of the flank and fine striae which flex slightly at midflank.

Discussion: The specimens from Oregon are slightly more involute and the whorl section is slightly higher than on the holotype of $D$. romani as figured by Huf $(1968, \mathrm{pl}$. 13, fig. 6). However, they are considered to fall within the range of variation since they compare very favorably with other figured specimens of $D$. romani, particularly those from Skye, Scotland (Morton, 1972, especially pl. 104 , figs. 5-6).

The reasons for including $D$. complanata in the synonomy of $D$. romani are discussed by Huf lop. cit., p. 89) and Morton (op. cit., p. 509). D. romani is typically recorded from the Humphriesianum zone although $D$. complanata has been collected from the Sauzei zone (Dorn, 1935, p. 120). Dorsetensia cf. D. subtecta Buckman

$$
\text { Pl. 4, figs. 9-10 }
$$

cf. 1892 Dorsetensia subtecta Buckman; p. 309, pl. 54, figs. 3-5; pl. 55, figs. 1, 2 .

Cf. 1935 Dorsetensia subtecta Buckman; Dorn, p. 103, pl. 21, fig. 2; pl. 23, fig. 1; pl. 25, fig. 7; pl. 29, fig. 4 
cf. 1951 Dorsetensia subtecta Buckman; Maubeuge, p. $34, \mathrm{pl} .12$, fig. 2 .

cf. 1968 Dorsetensia liostraca subtecta Buckman; Huf, p. 103, pl. 4l, fig. 1; pls. 42-46; pl. 47, fig. 1.

1973 Dorsetensia cf. D. subtexta Buckman (nomen null um); Imlay, p. 71, pl. 28, figs. 1-7; pl. 29, fig. 7 .

Material: Eight specimens.

Description: All of the Oregon specimens compared with D. subtecta are either fragmentary or flattened in the plane of coiling. The best preserved specimen available from the Izee area (CAS 13430) has already been figured by Imlay (1973, pl. 28, fig. 5). This specimen is refigured here for comparative purposes (pl. 4, fig. 9). This species is characterized by its fairly involute coiling with a moderately narrow umbilicus bordered by a high, step-like umbilical wall. The whorl section is compressed, ogival, much higher than wide with a well pronounced keel.

The ribbing is very weak (almost striate), flexes slightly on the flanks and projects onto the ventrolateral shoulder. The internal mold is almost smooth.

Discussion: These specimens are considered conspecific with other Oregon specimens of D. cf. D. subtecta (nomen coprectum, Imlay, Zoc. cit.) which differ from D. subtecta in having a slightly stouter whorl section. It should be 
noted that the "liostraca group" of Buckman (1892, p. 308) consisting of the very similar forms $D$. subtecta, D. tecta and D. L iostraca probably consists of variants of a single species (Morton, 1972, p. 506) that Westermann and Riccardi have called $D$. Liostraca, the most common name (1972, p. 104).

$$
\begin{gathered}
\text { Dorsetensia sp. A } \\
\text { P1. 4, fig. } 11
\end{gathered}
$$

Material: Two specimens.

Description: The specimen figured here (CAS 13442) has already been described and figured by Imlay (Dorsetensia sp. indet., p. $72, \mathrm{pl} .30$, figs. 5,6$)$ and the reader is referred to this work.

Discussion: This ammonite (from Locality B) was included because it is the best preserved specimen of Dorsetensia collected from the Izee area. One poorly preserved fragment from section 3 appears to be similar in whorl section, has a similar keel and appears smooth as with the outer whorl of $D$. sp. indet. of Imlay.

This species may be related to $D$. hannoverana which it resembles in some respects (see especially Morton, 1972, pl. 105, figs. 23, 24). However, D. sp. A is more involute $(u=29 \mathrm{cf}$. $u$ mean for skye specimens $=33.6$, $\sigma=2.9)$ and its whorl breadth to whorl height ratio 
is lower $(\mathrm{Wb} / \mathrm{Wh}=0.62 \mathrm{cf}$. $\mathrm{Wb} / \mathrm{Wh}$ mean for skye specimens $=0.86, \sigma=0.11$ ).

$$
\begin{aligned}
& \text { Dorsetensia sp. B } \\
& \text { P1. 5, figs. } 1-2
\end{aligned}
$$

1973 Do rsetensia cf. D. complanata Buckman; Imlay, p. 72 , pl. 29, figs. 5,6 .

Material: Six specimens.

Dimensions: Specimen no. D Ud $\mathrm{Rd}$ u

$\begin{array}{lrrrr}\text { F } 3-31-127 & c .31 & c .9 & 8 & 29 \\ \text { F } 3-31-149 & 37 & 10.6 & 9 & 29 \\ \text { F5 -5 -81 } & 40 & c .13 & 11 & 33 \\ \text { F5-5-97 } & c .26 & 8.5 & c .8 & 33\end{array}$

Description: These specimens are moderately evolute with a shallow umbilicus bordered by a low umbilical wall that is vertical at its base but rounds rapidly into the flattened flanks. The whorl section was probably somewhat compressed. A distinct keel is present.

On the inner whorls the simple ribs are broad with narrow interspaces and tend to be rursiradiate to rectiradiate in trend. At umbilical diameters greater than about $8 \mathrm{~mm}$, the ribs become more distant and predominantly rectiradiate. They arise near the umbilicus, are strongest on the lower two-thirds of the flanks after which point they rapidly become obsolete.

Discussion: These specimens appear to be identical with D. cf. D. complanata (Imlay, loc. cit.) which differs quite 
markedly from D. complanata Buckman (1892, p. 306, pl. 53, figs. 1-10; pl. 54, figs. 1-2) in the nature of the ribbing. Dorsetensia ? sp. Pl. 3, fig. 7

Material: Two specimens.

Dimensions: Specimen no.

D Ud $\quad$ Rd $\quad$ u

$\begin{array}{rrrrr}\text { *F5-4-93 } & \text { c. } 36 & 11 & 13 & 31 \\ \text { F5 -4-97 } & 25.5 & 8 & 9 & 31 \\ \text { * Distorted slightly } & & & \end{array}$

Description: This species is represented by two fairly well preserved specimens that are characterized by their moderately evolute coiling with an umbilicus bordered by a high, steep umbilical wall that rounds into the slightly flattened to convex flanks. The whorl section is low, slightly compressed with a sub-tabulate venter bearing a high, simple keel.

The ribs are strong, fairly distant and simple, arising from the umbilical shoulder, passing rectiradiately across the flanks and projecting ventrally very slightly. The ventral ends of the ribs fade well before reaching the keel.

Discussion: This species bears resemblances to Dorsetensia hannoverna (Morton, 1972, p. 513, pl. 105, figs. 11-12, 15-16, 23-24; and synonomy) in nearly all respects except that the ribbing is simple and the keel is not bisulcate 
(D. hannoverana is only sometimes bisulcate). Because these specimens have simple ribs, are small, moderately evolute and have rounded umbilical walls, it becomes difficult to separate this species from Sonninia, particularly in the absence of a septal suture for study. It is placed tentatively in Dorsetensia because there is no evidence of tuberculation and because of the general resemblance to $D$. hannoverana.

Genus Pelekodites Buckman, 1923

Pelekodites silviesensis Imlay

P1. 5, figs. 4-5

1973 Pelekodites silviesensis Imlay; p. 74, pl. 34, figs. 5-18.

Material: Twenty-six specimens.

Dimensions: Specimen.

D

Ud

$\mathrm{Rd}$

u

\begin{tabular}{|c|c|c|c|}
\hline $\begin{array}{l}\text { F2-52-40 } \\
\text { *F3-30-41 } \\
\text { F3-30-244 } \\
\text { F3-30-266 } \\
\text { F3-30-281 } \\
\text { F3-30-413 } \\
\text { F3-31-131 } \\
\text { F5-4-57 } \\
\text { *F5-4-60 } \\
\text { F5-4-62 } \\
\text { F5-4-63 } \\
\text { F5-4-65 } \\
\text { F5-4-66 } \\
\text { F5 } 4-69 \\
\text { F5-5-83(1) } \\
\text { F5-5-106 }\end{array}$ & $\begin{array}{l}16.5 \\
18 \\
20 \\
22 \\
18 \\
20.5 \\
18 \\
17.1 \\
29 \\
21 \\
23 \\
23.1 \\
22.8 \\
16.9 \\
\text { c. } 21 \\
26\end{array}$ & $\begin{array}{l}5.9 \\
7.4 \\
7.4 \\
9.5 \\
7.7 \\
7 \\
5.9 \\
6 \\
10.4 \\
7.8 \\
7.8 \\
8 \\
8.1 \\
6.5 \\
7 \\
10\end{array}$ & \begin{tabular}{r}
$c .16$ \\
11 \\
\hdashline 18 \\
-- \\
7 \\
-- \\
-- \\
16 \\
13 \\
$c .14$ \\
$\overline{15}$ \\
17 \\
-- \\
13
\end{tabular} \\
\hline
\end{tabular}

* Slightly distorted

Description: This species is small and evolute with a 
wide, shallow umbilicus bordered by a low, vertical to rounded umbilical wall. The whorl section was probably ovate, higher than wide, with gently convex flanks and an inconspicuous keel.

The ribs are mostly simple and fairly strong. They arise near the umbilical shoulder, pass prorsiradiately across the lower part of the flank, recurve backwards (sometimes strongly) on the middle part of the flank and then project slightly onto the ventral surface where they fade.

None of the specimens are complete so that the peristome is not available for inspection.

Discussion: These specimens are considered conspecific with the Oregon material abundantly figured by Imlay (loc. cit.)

Pelekodites dobsonensis Imlay

Pl. 5, fig. 6

1973 Pelekodites dobsonensis Imlay; p. 74, pl. 34, figs. 1-4.

Material: Five specimens.

Dimensions: Specimen no.

D Ud u

$\begin{array}{llll}\text { F } 3-30-230 & 25.5 & 8.6 & 34 \\ \text { F } 3-30-366 & 33.3 & 11.7 & 35 \\ * \text { F } 3-31-35 & 40 & 14 & 35 \\ \text { *F5-5-83 } & 42 & 16.2 & 39\end{array}$

* Lappets present 
Description: Most of these specimens are internal molds with conellae attached.

The specimens are large for the genus, evolute, egressing at maturity with a low to moderately high, rounded umbilical wall. The whorl section is compressed with flattened flanks and a somewhat tabulate venter bearing a low keel.

The ribbing is mostly simple and backwardly inclined, becoming distant and weaker on the body chamber. Two of the specimens bear lappets that are narrow near the aperture and fairly elongate, becoming spatulate anteriorly (see fig. 18). The lappets are marked with fine, dense growth striae.

Discussion: This is a microconchiate group most resembling $P$. do bsonensis Imlay, op. cit. (especially pl. 34, fig. 3). This is the first record of $P$. dobsonensis with the lappets intact.

Pelekodites cf. P. zurcheri (Douvillé)

$$
\text { Pl. 5, fig. } 3
$$

cf. 1968 Sonninia (Poecilomorphus) boweri boweri Buckman; Huf, p. 36, pl. 1, figs. 6-7; pl. 2, figs. 1-5.

cf. 1975 Pelekodites zurcheri (Douvillé); Morton, p. 64, pl. 10, figs. 7-10, 13-16.

Material: One specimen.

Dimensions: Specimen no.

D

Ud

$\mathrm{Rd}$

$\mathrm{u}$

F 5-5-1

38.9

16.2

9

c. 15

42 


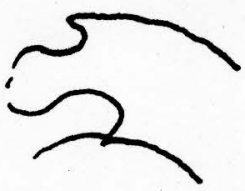

Pelekodites dobsonensis Imlay

Specimen F3 - $31-35$

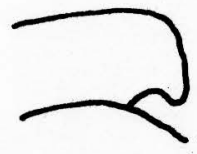

Pelekodites sp.

Specimen F5 - $5-84$

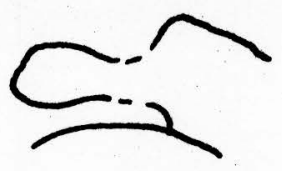

Pelekodites cf. P. zurcheri (Douvillé)

Specimen F5 - 5- 1

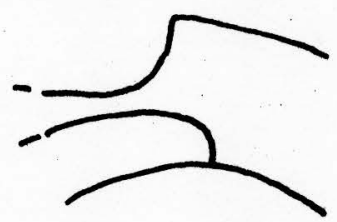

Pelekodites dobsonensis Imlay

Specimen F3 - $31-76$

Not to scale.

Figure 18. Sketches showing the variety of lappets displayed by species of Pelekodites from the Izee area.

Description: This specimen is an internal mold with a majority of the shell material adhering.

This rather large specimen is characterized by its evolute coiling with an egression of the body chamber so that the coiling is almost advolute in the last half whorl. The umbilicus is wide and fairly deep, bordered by the step-like umbilical wall. The visible whorls are compressed with flat flanks and a narrow tabulate venter bearing an 
indistinct keel.

The ribbing is convex, strongest on the flanks, becoming broader and fading ventrally. It is much weaker on the last part of the last whorl where the shell material is not present. Long, anteriorly swollen lappets are present (see fig. 18) bearing dense, fine growth striae. Septa are not evident so that the length of the body chamber is unknown.

Discussion: This specimen compares with the material figured by Huf (Zoc. cit. ) except that the whorl section is not so inflated. In this respect it is closer to the specimens from Scotland figured by Morton except that mature examples of this species are smaller (Morton, 1975, p. 65, text-fig. 6). This Oregon specimen of Pelekodites appears to be younger (Sauzei zone) than recorded examples of $P$. zurcheri (Sowerbyi Zone) from Europe.

$$
\text { Pelekodites spp. }
$$

Material: Two specimens.

Dimensions: Specimen no. D Ud u

$\begin{array}{lccc}\text { F } 3-30-262 & c .25 & 10.2 & 41 \\ \text { F } 5-5-84(1) & 26.8 & 10.7 & 40\end{array}$

Discussion: These small specimens are assigned to Pelekodites because they both bear lappets (see fig. 18), display evolute coiling and possess backwardly inclined 
ribbing. The lappets on both specimens are slightly dorsally inclined. Specimen F3-30-262 possesses much sharper ribbing than $P$. silviesensis, is smaller and more densely costate than $P$. dobsonensis and differs from $P$. zurcheri also in the sharpness of its costation.

Specimen F5-5-84 (1) compares most favorably with $P$. zurcheri but is too poorly preserved to warrant specific designation.

Genus Poeci.lomorpirus Buckman, 1889

Poecizomorphus varius Imlay

$$
\text { Pl. 5, fig. } 7
$$

1973 Poecilomorphus varius Imlay; p. 75, pl. 25, figs. 1-16.

Material: Two specimens.

Dimensions: Specimen no.

D Ud

$\mathrm{Rd}$ u F3-31-185 19 4 30 21

Description: Specimen F3-31-185 is an external mold whereas specimen F3-31-202 consists of a poorly preserved internal and external mold.

This species is involute, compressed, with a narrow umbilicus bordered by a low, fairly steep umbilical wall that rounds rapidly into the flattened flanks. A low (laterally sulcate?) keel is present on part of one specimen.

On the smaller specimen the ribs are dense and falcate. 
ribs are sharp and strongly rursiradiate.

Discussion: Poecilmorphus varius differs from specimens of oppelia subradiata?, collected from the Izee area, in being less involute and the ribs being strongly rursiradiate and falcate instead of falcoid.

Family STRIGOCERATIDAE Buckman, 1924

Genus Strigoceras Quenstedt, 1886

Strigoceras cf. S. Zanguidum (Buckman)

$$
\text { P1. 5, fig. } 8
$$

1964b Strigoceras cf. S. Zanguidum (Buckman); Imlay, p. B37, pl. 23, figs. 2-4, 8 .

non 1972 Strigoceras cf. S. Z anguidum (Buckman); Sato, p. 285, pl. 34, figs. 12, 13 .

? 1973 Strigoceras cf. S. I anguidum (Buckman); Imlay, p. 76, pl. 36, figs. 13, 17-21.

Material: one specimen.

Timensions: Specimen no. D Ud Rd u $\begin{array}{lllll}F 5-5-11 & 30 & 5 & 15 & 17\end{array}$

Description: This specimen is extremely involute with a very high, sub-oxyconic whorl section. The exceedingly small umbilicus is bordered by a low, rounded umbilical wall that passes rapidly into the flattened flanks. Where preserved, the venter is seen to bear a fairly high keel. Ornamentation appears to be absent on the lowest 
ribs are sharp and strongly rursiradiate.

Discussion: Poecilmorphus varius differs from specimens of oppelia subradiata?, collected from the Izee area, in being less involute and the ribs being strongly rursiradiate and falcate instead of falcoid.

Family STRIGOCERATIDAE Buckman, 1924

Genus Strigoceras Quenstedt, 1886

Strigoceras cf. S. Zanguidum (Buckman)

$$
\text { P1. 5, fig. } 8
$$

1964b Strigoceras cf. S. Zanguidum (Buckman); Imlay, p. B37, pl. 23, figs. 2-4, 8 .

non 1972 Strigoceras cf. S. Z anguidum (Buckman): Sato, p. 285, pl. 34, figs. 12, 13 .

? 1973 Strigoceras cf. S. Z anguidum (Buckman); Imlay, p. 76, pl. 36, figs. 13, 17-21.

Maleriat: one specimen.

Nimensions: Specimen no. $\quad \mathrm{D} \quad$ Ud $\quad$ Rd $u$ $\begin{array}{lllll}\text { F } 5-5-11 & 30 & 5 & 15 & 17\end{array}$

Description: This specimen is extremely involute with a very high, sub-oxyconic whorl section. The exceedingly small umbilicus is bordered by a low, rounded umbilical wall that passes rapidly into the flattened flanks. Where preserved, the venter is seen to bear a fairly high keel. Ornamentation appears to be absent on the lowest 
part of the flanks (on the internal mold) but the upper part bears broad, falcoid ribs that become stronger and markedly rursiradiate ventrally. The wide ventral ends of the ribs fade before reaching the keel.

Discussion: This specimen is most similar in degree of involution and style of ribbing to some larger specimens collected from Alaska (Imlay, 1964b) except that the ribs are slightly broader.

Family HAPLOCERATIDAE Zittel, 1884

Genus Lissoceras Bayle, 1879

Lissoceras hydei Imlay

Pl. 5, figs. 9-10

1973 Lissoceras hydei Imlay; p. 77, p1. 40, figs. $24-33$.

Material: Eight specimens.

limensions: Specimen no. D Ud $\mathrm{Rd}$ u $\begin{array}{lllll}\text { F 3-17-92 C. } 32 & 7.5 & \text { c.50 } & 23\end{array}$

Description: These specimens are mostly fragments or corroded and flattened internal molds.

This species is characterized by its involute coilin with a narrow umbilicus bordered by an extremely low umbilical wall that passes evenly into the flattened or gently convex flanks of the high whorl section.

On the smaller whorl fragments the weak, dense ribs 
are prorsiradiate on the lower third of the flank and rursiradiate on the remainder of the flank. At umbilical diameters greater than $5 \mathrm{~mm}$. or so the costation is extremely weak to absent on the lower two-thirds of the flank but is quite strong and still rursiradiate on the ventro-lateral shoulder and upper flank.

Discussion: These specimens are considered conspecific with other examples of $L$, hydei collected from the Izee area. As noted by Imlay (Zoc. cit.), L. hydei has the same general appearance as Bradfo rdia helenae Renz (Arkell, et al. , p. L275, fig. 318, la, b) but in Bradfordia the umbilical wall forms a sharp raised edge.

Family OPPELIIDAE Bonarelli, 1894

Genus Oppelia Waagen, 1869

oppelia subradiata ? (J. de C. Sowerby)

$$
\text { P1. 5, figs. } 11-12
$$

? 1938 Oppelia subradiata (J. de C. Sowerby); Roman, pl. 13, fig. 141 .

? 1951 Oppelia (Oppelia) subradiata (J. de C. Sowerby); Arkell, p. 50, test-fig. 11 .

? 1971 Oppelia subradiata (J. de C. Sowerby); Sturani, p. 112, pl. 7 figs. 2, 3.

? 1971 Oppelia (Oppel ia) ? subradiata (J. de C. Sowerby); Morton, p. 271, pl. 40, figs. 3-4.

? 1973 Oppel ia cf. 0. subradiata (J. de C. Sowerby); Imlay, p. 78, pl. 40, fig. 13 .

Material: Three specimens. 
Description: These poorly preserved specimens are very involute forms with smooth lower flanks and fine, falcoid ribs on the upper flanks.

Discussion: These specimens are considered conspecific with 0 . subradiata, as listed in the synonomy, as far as the poor preservation allows comparison.

$$
\begin{aligned}
& \text { Genus oecotraustes waagen, } 1869 \\
& \text { Oecotraustes sp. } \\
& \text { Pl. 5, fig. } 13
\end{aligned}
$$

Material: One specimen.

Dimensions: specimen no. Un. Sn. Loc. A $\# 1$ (2a)

D Ud

Rd

$\mathrm{u}$

Description: This specimen is a small, involute form with a narrow umbilicus bordered by a rounded umbilical wall. on the outermost preserved whorl, the umbilical wall becomes higher and slight egression occurs, resulting in elliptical coiling. The whorl section is compressed with gently rounded flanks and a fastigate, keeled venter. The costation, consisting of dense, fine, rursiradiate ribs that project onto the venter, becomes stronger adorally and appears to be restricted to the upper third of the flank.

Discussion: This specimen is assigned to the genus Decotraustes because of its general resemblance to oppelia 
combined with elliptical coiling of the outer whorl.

Family STEPHANOCERATIDAE Neumayr, 1875

Genus No rmannites Munier-Chalmas, 1892

No rmannites (Normannites) orbignyi Buckman

$$
\text { P1. 5, fig. } 14
$$

1845 Ammonites braikenridgii d'orbigny; pl. 135.

1927 No rmannites orbignyi Buckman; pl. 734.

1954 Normannites (Normannites) orbignyi orbignyi Buckman; Westermann, p. 135, pl. 5, figs. 3-4; pl. 6, fig. 1 .

? 1971 Stephanoceras (No rmannites) ? orbignyi (Buckman); Morton, p. 282, pl. 51, figs. 1, 2 .

1973 Normannites (Normannites) orbignyi Buckman; Imlay, p. 82, pl. 41, figs. 9, 10, 18, 20.

Material: one specimen.

Dimensions: Specimen no. D Ud pRd sRd u Wh $\begin{array}{ccccccc}\text { F3-39-7 } & 31.9 & 13.5 & 11 & 24 & 42 & c .9\end{array}$

Description: This specimen is evolute with a wide, fairly shallow umbilicus bordered by a rounded umbilical wall. The whorl section was probably somewhat depressed before post-depositional crushing. The flanks are rounded and the venter probably somewhat flattened. The outer part of the last whorl appears to be non-septate but the specimen is incomplete and no lappets are preserved. The costation is bold. Some of the primaries are slightly curved. They trend prorsiradiately or rectiradiately 
to the middle of the flank where prominent tubercles mark the furcation points. All the primary ribs give rise to pairs of secondary ribs, with an occasional intercalated rib between the pairs, that trend approximately rectiradiately onto the venter.

Discussion: This specimen is considered to fall within the range of variation of $N$. orbignyi Buckman. N. orbignyi is the type species for the genus Normannites which is now considered a microconchiate dimorph, probably of Stephanoceras.

$$
\begin{aligned}
& \text { Normannites cf. N. vigorosus (Imlay) } \\
& \text { P1. 5, figs. 15-17 } \\
& \text { cf. } 1961 \text { a Dettermanites vigorosus Imlay; p. 472, pl. } \\
& 64 \text {, figs. } 1-3 \text {. } \\
& \text { cf. } 1962 \text { Dettermanites vigorosus Imlay; p. Al2, pl. } \\
& 4 \text {, figs. 1-9. }
\end{aligned}
$$

Material: Eleven specimens.

Description: All the specimens are poorly preserved, incomplete individuals or whorl fragments.

The coiling is moderately evolute producing a fairly wide umbilicus bordered by a steeply inclined umbilical wall that rounds evenly into the convex flanks. Before crushing, the whorl section was probably wider than high. The ribbing, where the shell material is preserved, is very strong, consisting of distant, slightly curved and 
slightly prorsiradiate primary ribs that give rise to two (rarely three) slightly weaker prorsiradiate secondary ribs. At the point of furcation at about mid-flank, small, acute tubercles are developed. Pairs of secondary ribs are often separated by intercalated ribs. On specimens consisting only of an internal mold, all the ornamentation is weaker.

Specimen F3-38-11 (pl. 5, fig. 17) is a fragment of the outer whorl of a mature individual. It is an internal mold showing a constricted aperture followed by flared lappets.

Discussion: The genus Dettermanites was erected in 1961 for a group of rather large, upper Bajocian microconchs that bore a resemblance to certain stephanoceratids. It was differentiated from Normannites on the basis of the suture line and the larger number of secondary ribs (Imlay, $1964 \mathrm{~b}, \mathrm{p}$. B6) but it has since become apparent that the relationship between these two groups is so close that the erection of a new genus is not warranted. Hence, Dettermanites is here regarded as a junior subjective synonym and is rejected in favor of Normannites (see also, Imlay, 1964b, p. B5-6; 1973, p. 84).

The specimens from the Izee area differ slightly from the type material in the ornamentation being more suppressed on the internal mold and in the whorl section probably being a little more compressed, although poor preservation 
hinders detailed comparison.

$$
\begin{aligned}
& \text { Normannites sp. } \\
& \text { P1. 5, fig. } 18
\end{aligned}
$$

Material: One specimen.

Description: This ammonite is a small (D estimated $45 \mathrm{~mm}$ ), mature individual that is fairly evolute with the body chamber egressing slightly.

The ribbing on the septate whorls is poorly preserved but on the body chamber sharp, moderately spaced primary ribs incline forward on the lower two-thirds of the flanks and terminate in prominent, tetrahedral tubercles. From these tubercles arise two or three prorsiradiate, slightly weaker secondary ribs. Intercalation of secondary ribs results in a ratio of secondaries per primary of over $3: 1$. The body chamber is terminated by a constriction, followed by a flaring and, finally, elongate (incomplete) lateral lappets.

Discussion: This specimen is assigned to the genus No rmannites because it is a microconch resembling Stephanoceras. It differs from many of the described species of Normannites in having tetrahedral-like tubercles, a high ratio of secondary to primary ribs and rather unusual lappets.

Genus Stephanoceras Waagen, 1869

Stephanoceras nodosum (Quenstedt) 


$$
\text { P1. 6, figs. } 1,3
$$

1932 Stephanoceras nodosum Quenstedt em. Weisert; Weisert, p. 136, pl. 15, figs. 1-2.

1951 Stephanoceras nodosum Quenstedt; Maubeuge, p. 57, pl. 10, fig. 6 .

1951 Stephanoceras aff. nodosum Quenstedt; Maubeuge, p. 58-60, pl. 6, figs. 5, 6; pl. 1l, fig. 3 .

1964b Stephanoceras cf. S. nodosum (Quenstedt); Imlay, p. B46, pl. 16, figs. 7, 8 .

1967 Stephanoceras aff. S. nodosum (Quenstedt); Imlay, p. 89 , pl. 7, figs. 4,5 .

1971 Stephanoceras (Stephanoceras) nodosum (Quenstedt); Morton, p. 276, pls. 42-45.

1973 Stephanoceras cf. S. nodosum (Quenstedt); Imlay, p. 87, pl. 44, figs. 7-11.

Material: Eight specimens.

Description: These specimens are evolute and characterized by large tubercles situated at approximately the middle of the flank. The umbilicus is wide, the umbilical wall low and the whorl section slightly depressed.

The sharp primary ribs are characteristically straight but sometimes curved. They are widely spaced, rectiradiate and give rise to, usually, three rectiradiate to slightly prorsiradiate secondary ribs. Intercalated ribs occasionally arise at the zone of furcation.

Discussion: The ammonites listed in the synonomy show a certain amount of variation in such characteristics as strength of the tubercles, degree of involution and density 
and strength of ribbing. Such variation is probably infraspecific. Some of the incipient splitting seems to have stemmed from the work of Maugeuge but his $S$. nodosum and $S$. aff. nodosum were synonomised by Morton (Zoc. cit.) and this procedure is followed here.

$$
\begin{gathered}
\text { Stephanoceras sp. A } \\
\text { Pl. 6, fig. } 2
\end{gathered}
$$

1973 Stephanoceras sp. A; Imlay, p. 86, pl. 45, fig. 10 .

Material: One specimen.

Description: This specimen consists of a very poorly preserved internal mold complemented by an external mold on which details are better preserved.

The innermost whorls are obscured by oyster growth but the earliest visible whorls bear fine, strongly prorsiradiate primaries that bifurcate below the line of involution. The furcation points are slightly swollen. Intercalated secondary ribs usually separate the forked ribs. On the outermost preserved whorl, the ribbing is decidedly stronger, the rapidly elongate tubercles slightly more pronounced and on the most adoral portion of the last whorl (which may represent a collar on the adult body chamber), dense, fine, prorsiradiate and flexuous striae are present.

Discussion: This specimen is very similar to a specimen described by Imlay and called by him Stephanoceras sp. A 
(2oc. cit.). This individual could represent the macroconch dimorph of Lupherites, as suggested in the discussion of L. senecaensis on p. 150 .

$$
\begin{aligned}
& \text { Stephanoceras spp. } \\
& \text { P1. 6, figs. } 6,8
\end{aligned}
$$

Discussion: Many poorly preserved whorl fragments whose style of ribbingsuggests assignment to the genus Stephanoceras were collected from the Snowshoe Formation. The fragments figured here are some of the largest collected but many more smaller fragments of uncertain specific affinities were also found.

$$
\begin{gathered}
\text { Stephanoceras n. sp. ? } \\
\text { Pl. 6, fig. } 7
\end{gathered}
$$

Material: Eight specimens.

Description: These specimens are all poorly preserved fragments.

This species is involute with a deep umbilicus bordered by a steeply inclined umbilical wall. The whorl section was probably only slightly compressed on the inner whorls but on the outermost whorls, the whorl section is much higher than wide, with gently convex flanks.

The gently curved primary ribs are strong, closely spaced on the inner whorls, becoming more distant with growth. In outline, the adoral slope if much gentler than 
the adapical slope. They arise a short distance from the umbilical seam and cover the lower quarter to a third of the flank, at which point they terminate in small, acute tubercles that are reduced to swellings on some specimens. From the tubercles, two secondary ribs arise that are extremely long, appreciably weaker than the primary ribs and show a rounded rather than an asymmetric outline. Further secondary ribs arise by intercalation, resulting in a ratio of secondary to primary ribs of a little over $3: 1$. The secondary ribs are gently prorsiradiate on the middle part of the flank but recurve backwards on the upper part to approach the venter in a rectiradiate manner.

Discussion: The ribbing on these specimens is similar to Stephanoceras pyritosum Quenstedt (Maubeuge, 1951, p. 56, pl. 1l, fig. 2; Morton, 1971, p. 281, pl. 47, figs. 3, 4; pls. 48, 49; pl. 50, figs. 1, 2) but differs in being not quite as sharp. Also, the tubercles are more prominent. There is a similarity between these specimens from the Izee area and one specimen of Stephanoceras (Skirroceras) kirschneri Imlay from the Emigrant Creek area (Imlay, 1973, pl. 42, figs. 3, 4 only) except that the primary ribs on this specimen are longer and the tuberculation weaker. These specimens probably represent a new species but better preserved material must be collected before a new specific name could be applied with confidence. 
Subgenus Skirroceras Mascke, 1907

Stephanoceras (Skirroceras) juhlei Imlay

P1. 6, fig. 4, Pl. 7, fig. 1

1964b Stephanoceras (Skirroceras) juhlei Imlay; p. B47, pl. 16, figs. $1,3-6, \mathrm{pl} .17$.

1973 Stephanoceras (Skirroceras) juhlei Imlay; Imlay, p. 88, pl. 43, figs. 1-7, 15 .

Material: Fourteen specimens.

Dimensions: Specimen no. D Ud Wh Wb u

\begin{tabular}{|c|c|c|c|c|}
\hline$F 1-21-31$ & 300 & 182 & -- & -- \\
\hline & -- & 68 & 17 & -- \\
\hline F 3-14-87 & c. 52 & c. 12 & 10 & c. 42 \\
\hline *F $3-31-1$ & -- & 14 & 10 & c. 36 \\
\hline F3-31-2 & 32 & 13 & -- & -- \\
\hline & & 9 & 9 & \\
\hline $\begin{array}{l}\text { F3-32-2 } \\
\text { F } 3-35-14\end{array}$ & -- & $\begin{array}{l}14 \\
15\end{array}$ & $\begin{array}{l}12 \\
--\end{array}$ & -- \\
\hline$F 3-35-14$ & c. 35 & 7 & 13 & -- \\
\hline
\end{tabular}

* Slightly distorted

lescription: This species is evolute in its early whorls and gradually uncoils during growth to give the appearance of a serpenticone at large diameters. The umbilicus, therefore, is wide and shallow.

The primary ribs are sharpest on the earlier whorls, are fairly straight and dense and incline gently forward across the lower part of the flank. Just below the midflank position, tuberculate furcation points give rise to two or three secondary ribs (with a fourth ribs occasionally intercalated) that are rectiradiate or gently prorsiradiate. 
The secondary ribs become more distant with growth and both ribbing and the tubercles become weaker. The suture, poorly exposed on two specimens, shows broad, adapically elongate saddles. No specimen is complete so that the length of the body chamber is unknown.

Discussion: These specimens are considered conspecific with the material from Alaska and Oregon figured by Imlay (see synonomy).

According to the diagnoses, $S$. (S.) juhlei can be differentiated from $S$. (S.) kirschneri by its finer ribbing, smaller tubercles positioned lower on the flanks, by more slowly enlarging whorls and a depressed whorl section. Also, the primary ribs are straighter on $S$. (S.) juhlei and the secondary ribs more sparse. The data for some of the holotypes published by Imlay $(1964 \mathrm{~b}, \mathrm{p} . \mathrm{B} 47, \mathrm{~B} 48)$ is presented graphically in fig. 19. These two forms are closely related, if not variants of the same species, and they are usually difficult to separate. According to Imlay, $S$. (S.) kirschneri ranges stratigraphically higher than $S$. (S.) juhlei although their ranges overlap in the upper part of the Sauzei Zone (Imlay, 1973, p. 21). Such a stratigraphic distinction is not evident in the collections made from the Izee area during this study.

Also, a thorough statistical evaluation of all the type material would help more clearly establish the 


$$
\text { 娄 }
$$


relationship between these North American species and the

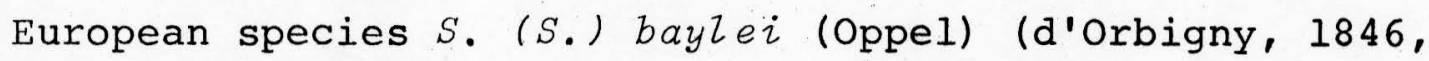
pl. 133) and S. (S.) macrum (Quenstedt) (Buckman, 1921, pl. 248) .

Stephanoceras (Skirroceras) aff. S. (S.) juhlei Imlay P1. 6, fig. 5

1973 Stephanoceras (Skirroceras) aff. S. (S.) juhlei Imlay; p. 88 , pl. 43, figs. 8,9 .

Material: Eight specimens.

Dimensions: Specimen no.

D

$$
\begin{aligned}
& \text { F3-32-27 } \\
& \text { F3 } 35-6(4) \\
& \text { F3-35-6 (7) } \\
& \text { F3-35-14 }
\end{aligned}
$$

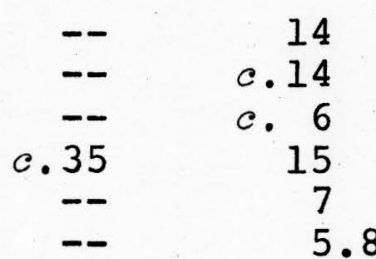

Ud

$\mathrm{pRd}$

u

\section{2}

14

16

$--$

13

15

Description: These specimens are mostly fragmentary external molds, all from section 3 .

They are very similar to Stephanoceras (Skirroceras)

juhzei Imlay, as described earlier, but differ in being slightly more involute and possessing much denser primary ribs that are also higher and coarser on the outer whorls.

Discussion: These specimens are considered conspecific with $S .\left(S_{.}\right)$aff. $S_{\text {. }}\left(S_{.}\right)$juhl ei, collected from beds correlating with the upper part of the Humphriesianum zone in the Seneca area (Imlay, 1973, p. 28). 
Stephanoceras (Skirroceras) kirschneri Imlay

$$
\text { P1. 6, fig. } 9
$$

1964b Stephanoceras (Skirroceras) kirschneri Imlay; p. B47, pl. 18, figs. 1-4; pl. 19.

1973 Stephanoceras (Skirroceras) kirschneri Imlay; p. $87, \mathrm{pl} .30$, fig. 13; pl. 42, figs. 1-10.

Material: Twenty-four specimens.

Description: All the specimens are fragments or incomplete molds.

The inner whorls are moderately involute but egression occurs with growth so that larger specimens are very evolute. The umbilical wall is low and slopes evenly into the convex flanks.

The primary ribs, which may vary in trend, are strong, usually gently convex and terminate in prominent, elongate tubercles just below the middle of the flank. From these tubercles arise three or four weaker secondary ribs that trend rectiradiately to prorsiradiately across the upper part of the flanks. The secondary ribs become stronger with growth as do the tubercles.

Discussion: The differences between S. (S.) kirschneri and the closely related species $S .\left(S_{.}\right)$juhlei are described in the discussion of the latter on p. 140.

Genus Stemmato ceras Mascke, 1901

Stemmatoceras aff. S. albertense McLearn 


$$
\text { P1. 8, fig. } 1
$$

aff. 1928 Stemmatoceras albertense McLearn; p. 20, pl. 5-7. aff. 1957 Stemmatoceras albertense McLearn; Frebold, p. 50, pl. 2l, figs. 2a, b; pl. 23, figs. la-c.

1967 Stemmatoceras n. sp. aff. S. al bertense McLearn; Imlay, p. 91, pl. 10, figs. 1-8; pl. 16, figs. $5-7$.

1973 Stemmatoceras aff. S. al bertense McLearn; Imlay, p. 89, pl. 46 , figs. $1-9$.

Material: Thirteen specimens.

Description: This species is represented by incomplete and fragmentary specimens, mostly internal molds.

The specimens are fairly evolute and show a whorl section that is depressed in the smaller fragments becoming even more depressed in the larger fragments.

The primary ribs are sharp, dense and fairly long, terminating in small, acute tubercles just above the middle of the flank. The primaries are somewhat flexuous and tend to be prorsiradiate. Two or three weaker secondaries, often separated by intercalated ribs, arise from the tubercles and incline prorsiradiately across the upper flank on smaller whorls to cross the venter transversely. On the larger, more depressed whorls the tubercles are closer to the ventro-lateral shoulder and the secondaries pass across the venter, from tubercle to tubercle more directly.

The ventral part of the suture exposed on one specimen appears to be identical with that of the holotype (McLearn, 
1928, pl. 7).

Discussion: These specimens, together with the specimens discussed by Imlay (1967, 1973), probably represent the variants of a new species of Stemmatoceras related to $S$. albertense but differing in having more closely spaced primaries on the inner whorls, more distant primaries on the outer whorls, slightly fewer and sharper secondary ribs and a slightly higher whorl section.

S. aff. S. albertense differs from $S$. sp., described herein, in being less depressed and in the ribbing being sharper and more dense.

Stemma toceras sp.

P1. 8, fig. 2

Material: Seven specimens.

Description: These fragments are characterized by an extremely depressed whorl section, over twice as wide as high. The whorl sides are very low and strongly convex. The venter is only gently arched (pl. 8, fig. 2).

The primary ribs are distant, strong and flexuous, terminating in small, pronounced tubercles. From each tubercle arises a pair of secondary ribs, separated from its neighboring pair by a single intercalated rib. The secondary ribs cross the venter transversely. When viewed in outline, they tend to have a steeper adapical than adoral 
slope.

Discussion: This species is close to the Teloceras pole of the Stephanoceras, Stemmato ceras, Tel oceras sequence in that the whorl section is very depressed. There is some resemblance, particularly in whorl shape, to Stemmatoceras $\mathrm{n}$. sp. undet. from Alaska described by Imlay (1964b, p. B48, pl. 20, figs. 1-4) but the material is not complete enough to make detailed comparisons.

Genus Cadomites Munier-Chalmas, 1892

Cadomites ? sp.

P1.8, figs. 3-4

Material: Two specimens.

Description: Both the internal and external molds of these fragments are available for study. Only the nontuberculate parts of the primary ribs are visible on the inner whorls, suggesting this ammonite was not evolute. The umbilical wall is fairly steep and the umbilical shoulder rounds evenly into the convex sides of the high whorls.

The sharp, dense primary ribs are extremely long, extending at least across the lower two-thirds of the flank. They arise from the umbilical seam, are strongly rursiradiate on the lowermost part of the flank but gradually straighten to terminate in radially elongate, sharp tubercles. The tubercles on the non-septate part of specimen F3-35-7 
(pl. 8, fig. 3) are stronger than on the septate portion. Three, or more rarely two, secondary ribs arise from each tubercle by furcation. The forked ribs are often separated by intercalated secondaries so that the ratio of primaries to secondaries remains approximately $3: 1$. The secondary ribs arch gently forward from the zone of furcation and then recurve gently backwards toward the venter. The suture line cannot be traced accurately.

Discussion: These specimens bear a resemblance to some of the specimens figured by Imlay and referred to Stephanoceras sp. C (1973, p. 86, pl. 44, figs. 1-4). However, these specimens, which Imlay questionably compares with Cadomites, are not as strongly tuberculate and have fewer secondary ribs.

The specimens from the Izee area are questionably referred to the genus Cadomites because of the sharpness and density of the ribbing (Arkell, et al., 1957, p. L290, fig. 342,8$)$ and the extraordinary length of the primary ribs that compare with those on several species of Cadomites (e.g. d'Orbigny, 1846, pl. 134, 138). The association on Section 3 with ammonites indicative of the upper Humphriesianum Zone does not preclude an assignment to Cadomites since this genus originated in late Humphriesianum Zone time but did not become abundant until the upper Bajocian (Westermann, 1964b, fig. 14; Westermann and Rioult, 1975, 
p. 875) .

When, and if, better preserved material becomes available showing the nature of the whorl section, a more confident assignment will be possible.

Genus Lupherites Imlay, 1973

Lupherites senecaensis Imlay

P1. 8, figs. 5-6, 8

1973 Lupherites senecaensis Imlay; p. 90, pl. 47, figs. $1-20$.

Material: Forty-eight specimens.

Dimensions: Specimen no. D Ud pRd sRd u

$\begin{array}{lccccc}\text { F6-1-0 } & \text { c. } 50 & \text { c. } 20 & 19 & -- & 40 \\ \text { F6-1-1 } & 59 & 20 & -- & -- & 34 \\ \text { F6-1-3 } & \text { c. } 27 & 11 & 24 & -- & 41 \\ \text { F6-1-8 } & 48 & 16 & 18 & 54 & 33 \\ \text { F6-1-17 } & 26.5 & 8.5 & -- & -- & 32 \\ \text { F6-1-19 } & * 60 & 23 & 16 & 50 & 38\end{array}$

* Estimated

Description: This species is represented mostly by fragmentary internal and external molds form the type silvies Member of the Snowshoe Formation.

The umbilicus is moderately wide and shallow, bordered by a low umbilical wall on the phragmocone and a slightly higher wall on the body chamber which is usually retracted to some degree. The whorl section was probably higher than wide with the flattened flanks rounding evenly into a slightly flattened venter. 
This species is variocostate. The inner, septate whorls bear extremely fine and sharp primary ribs that trend rursiradiately up the umbilical wall but become quickly and markedly prorsiradiate on reaching the umbilical shoulder. Some of the primary ribs bifurcate on the middle of the flank whereas others remain simple. None of the furcation points are tuberculate. Intercalated secondary ribs are common so that the ratio of secondary to primary ribs is approximately $3: 1$.

On the body chamber the ribbing becomes suddenly stronger, more widely spaced and tubercles develop at the points of furcation. The body chamber occupies at least one-fourth of a whorl on specimen F6-1-1 (pl. 8, fig. 8) but it is not complete. One coarsely ribbed fragment bears a short, dorsally flexed, rounded lateral lappet. Specimen F6-1-19 (pl. 8, fig. 5) is a large example that is entirely septate but the ribbing has become gradually (as opposed to suddenly) stronger and tubercles are developed. In all other respects, it is identical to $L$. senecaensis.

The suture line is complex with a long, irregularly trifid first lateral saddle.

Discussion: These specimens are considered conspecific with the type material from the snowshoe Formation in the Seneca area as figured by Imlay (Loc. cit.). The development of coarser, more distant costation and tubercles does 
not appear to be confined solely to the mature body chamber, however, although these are features characteristic of a late stage in the ontogeny.

This is a microconchiate species that could possibly be paired with the somewhat similar but larger Stephanoceras sp. A (see p. 136 and Imlay, op. cit., p. 86).

Family SPHAEROCERATIDAE Buckman, 1920

Genus Cho ndroceras Mascke, 1907

Chondroceras alzani (McLearn)

$$
\text { pl. 8, fig. } 9
$$

1928 Saxitoniceras all ani McLearn; p. 21, pl. 8, figs. 1,2 .

cf. 1948 Defonticeras oblatum (Whiteaves); Imlay, p. 19, pl. 5, figs. 1-5.

cf. 1957 Chondroceras al Zani McLearn var.; Frebold, p. 53, pl. 27, figs. 2a, b.

1964 Chondroceras alzani (McLearn); Frebold, p. 20, pl. 8, figs. 2-5.

cf. 1964 Chondroceras sp; Frebold, p. 21, pl. 8, fig. 6.

1964 Chondroceras azzani (McLearn); Imlay, p. B42, pl. 12, figs. 4-7, 9, 10 .

cf. 1967 Chondroceras cf. C. alZani (McLearn); Imlay, p. 93, pl. 6, figs. 1-3, 7, 8.

1973 Chondroceras allani (McLearn); Imlay, p. 81, pl. 40 , figs. 11,12 .

Material: Two specimens.

Dimensions: Accurate measurements could not be made because of the state of preservation. The diameter of specimen 
F3-35-5 was in excess of $40 \mathrm{~mm}$. and the last half whorl bears approximately eight primary ribs.

Description: Specimen F3-35-5, the best preserved specimen, is an internal mold with a considerable amount of shell material still adhering. The phragmocone is preferentially crushed and the whole test has been compressed slightly at right angles to the plane of coiling. It is still evident that this ammonite is highly involute with a very small umbilicus and that the final whorl egresses slightly, giving the appearance of a sphaerocone.

Short primary ribs on the earlier whorls pass prorsiradiately across the lower third of the flanks at which point three secondary ribs arise, recurving backwards across the middle and upper flanks to cross the venter transversely. On the body chamber, the ribs are more widely spaced and there are fewer secondary ribs per primary. The peristome is constricted. Where present, the test bears fine growth lines.

Discussion: In spite of the state of preservation, this specimen can be referred with confidence to Chondroceras allani (McLearn). Its ribbing is sharper than on the holotype but this can be considered as within the range of variation for this species since other figured examples of C. all ani are identical with specimen F3-35-5 (e.g. Imlay, 1964, pl. 12, fig. 4; Imlay, 1973, pl. 40, fig. 11). 
C. allani differs from $C$. defontii in being less globose and the ribbing being coarser.

$$
\begin{gathered}
\text { Genus Sphaero ceras Bayle, } 1878 \\
\text { Sphaeroceras sp. } \\
\text { Pl. 8, fig. } 7
\end{gathered}
$$

1973 Sphaeroceras sp.; Imlay, p. 82, pl. 40, figs. 14-16.

Material: One specimen.

Description: This specimen is an extremely small fragment of an external mold that displays involute, elliptical coiling. The elongate umbilicus is bordered by a low umbilical wall that rounds evenly into the convex flanks. The costation is sharp and consists of fine, dense primary ribs that pass prorsiradiately across the lower half of the flank at which point weaker secondary ribs arise by bifurcation and intercalation. These secondaries arch backwards gently, to approach the venter (which is not preserved) in a rectiradiate manner.

Discussion: Although the preservation is very poor, the manner of coiling and the style of costation suggests an assignment to the genus Sphaeroceras. Furthermore, this ammonite appears to be identical with the ammonites from the lower and middle Basey Member of the Snowshoe Formation that Imlay assigned to Sphaeroceras sp. (Imlay, 1973, especially pl. 40, fig. 16) . 
Family TULITIDAE Buckman, 1921

$$
\begin{gathered}
\text { Genus BulZatimorphites Buckman, } 1921 \\
\text { BulZatimorphites ? sp. } \\
\text { P1. 8, fig. } 10
\end{gathered}
$$

Material: Two specimens.

Description: Specimen F5-14-36 (pl. 8, fig. 10) is an incomplete individual whereas specimen F5-14-28 appears to be complete but is poorly preserved.

The coiling is markedly elliptical with egression of the last whorl causing a rapid enlargement of the small umbilicus. The specimens are small (D maximum $=c .26 \mathrm{~mm}$.). The whorl section is low, probably slightly higher than wide. The umbilical wall is extremely low, the venter broad and rounded.

Two fairly deep constrictions occur together just before egression of the outer whorl on the figured specimen. Other constrictions, that cut across the ribs, are also evident on the adoral half of the outer whorl which is less well preserved than the inner whorls.

The ribbing consists of short primaries that bifurcate on the lower third of the flank. The secondaries are rectiradiate and appear to be uninterrupted on the venter.

The peristome, preserved on specimen F5-14-28, is gently curved and projected slightly ventrally. It is 
preceeded by a weak constriction.

Discussion: The affinites of these ammonites are uncertain. They are very similar to Ammonites dimorphus d'orbigny (1846, pl. 14l, especially fig. 7) which is the type species, by original designation, of Dimorphinites (Arkell, 1955, p. 131). However, this genus has only ever been collected from Bajocian age rocks whereas the Oregon specimens are associated with Callovian ammonites.

The Oregon specimens agree with the familial and generic diagnoses of Bullatimorphites (Tulitidae) given in the "Treatise" (Arkell, et al., p. L292) and they are tentatively assigned to this genus until a more detailed study can be made.

$$
\begin{gathered}
\text { Family MACROCEPHALITIDAE Buckman, } 1922 \\
\text { Genus Xenocephalites spath, } 1928 \\
\text { Xenocephalites vicarius Imlay } \\
\text { Pl. 8, figs. 11-13 }
\end{gathered}
$$

1953b Xenocephalites vicarius Imlay; p. 78, pl. 28, figs. 1-8.

1964 a Xenocephalites vicarius Imlay; p. D14, pl. 1, figs. 23-27.

Material: Twenty-one specimens.

Description: These ammonites are all fairly small and somewhat compressed, consisting mostly of inner whorls. One large fragment is more inflated (F5-14-86(1)). 
The coiling is extremely involute to convolute with the narrow umbilicus being bordered by a steep, low umbilical wall. On larger specimens, the umbilicus widens as slight egression occurs.

The ribbing on the inner whorls is fine and dense. On the lower flank the ribs are concave but recurve backwards so that the general trend of the ribbing is rectiradiate. Some ribs are simple but most bifurcate at about the mid-flank position. Some intercalated secondaries occur. On the larger whorls the ribbing becomes coarser, more distant and somewhat prorsiradiate.

Discussion: These specimens are identical to specimens of $X$. vicarius already collected from the Izee area.

Genus Liz Zo ettia Crickmay, 1930

Lilloettia lilloetensis Crickmay

$$
\text { Pl. 8, fig. } 14
$$

1953b Lilloettia Zilloetensis Crickmay; Imlay, p. 77 , pl. 30 , figs. $1,2,4,8$.

1957 Lizloettia lizloetensis Crickmay; Arkell, et al., p. L294, fig. 352, 7a, b.

1967 Lizloettia Zizloetensis Crickmay; Frebold and Tipper, pl. 1, figs. 7-9; pl. 3, fig. 3 .

Material: One specimen.

Description: This rather poorly preserved specimen is characterized by being extremely involute and compressed. The inner whorls bear low, dense, prorsiradiate ribs that 
bifurcate near the middle of the flanks. The ribbing fades on the outer whorl which is terminated by a broad, prorsiradiate constriction confined to the lower part of the flank, followed by a swelling.

Discussion: This specimen is assigned to L. Zilloetensis because it is compressed and bears low, dense ribs on its inner whorls.

$$
\begin{gathered}
\text { Lilloettia buckmani (Crickmay) } \\
\text { Pl. 8, fig. } 16
\end{gathered}
$$

1953b Lizloettia buckmani (Crickmay); Imlay, p. 75, pl. 27, figs. 1-9.

1964 a Lilloettia buckmani (Crickmay); Imlay, p. Dl4, pl. 2, figs. 14, 15, 17, 18 .

Material: Four specimens.

Discussion: These specimens differ from the specimen assigned to $L$. lilloetensis in being much more inflated and possessing stronger ribbing. Consequently, they are assigned to $L$. buckmani which is the most coarsely ribbed and, next to $L$. milleri, the most inflated species of Lizro etia.

$$
\text { Lizloettia milzeri ? Imlay }
$$

? 1953b Lilloettia mill eri Imlay; p. 75, pl. 28, figs. 11, 13-15; pl. 29, figs. 14, 15 .

Material: One specimen.

Discussion: This poorly preserved ammonite fragment is 
characterized by being extremely depressed and involute, and in bearing low, rounded costae. It is assigned to $L$.

milzeri because it is so globose but it is too fragmentary to make the assignment with confidence.

Lilzoettia mertonyarwoodi ? Crickmay

Pl. 8, fig. 15

? 1953b Lilloettia mertonyarwoodi Crickmay; Imlay, p. $76, \mathrm{pl}$. 30, figs. 3, 5-7, 9-11.

Material: Two specimens.

Discussion: These very poorly preserved fragments of inner whorls are questionably assigned to L. mertonyarwoodi but much better preserved material must be collected before a confident assignment can be made.

Family KOSMOCERATIDAE Haug, 1887

Genus Kepplerites Neumayr and Uhlig, 1892

$$
\begin{gathered}
\text { Keppl erites spinosum Imlay } \\
\text { P1. 9, figs. } 1-2
\end{gathered}
$$

1953b Gowericeras spinosum Imlay; p. 99, pl. 53, figs. 8,11 .

Material: One specimen.

Description: This is a fairly evolute specimen with a wide umbilicus that is bordered by an umbilical wall that is steep at its base but rounds rather abruptly into the convex flanks. The whorl section on the inner whorls is extremely depressed but on the outer whorls it is slightly 
higher, renaining somewhat higher than wide however.

On the earlier whorls the primary ribs are sharp and prorsiradiate, terminating in acute tubercles at the point of maximum inflation. Two secondary ribs arising from each tubercle cross the flattened venter transversely (see pl. 9, fig. 2). On the outer whorls the primary ribs are rursiradiate on the umbilical wall and gently prorsiradiate on the lower flank. Because of poor preservation, it is difficult to determine the number of secondary ribs per primary rib but the ratio is probably in excess of $3: 1$.

Discussion: The genus Gowericeras is synonomised with Kepplerites following Arkell, et al. (1957, p. L298).

Family PARKINSONIIDAE Buckman, 1920

Genus Garantiana Mascke, 1907

$$
\begin{aligned}
& \text { Garantiana ? } \\
& \text { P1. 9, figs. 3-4 }
\end{aligned}
$$

Material: One specimen.

Description: This specimen is a fragment of an internal mold with some shell material adhering. The shell is fairly involute, embracing by a little more than one half. The umbilical wall is very high and steep on the lower whorls but lower on the outer whorl. The whorl section was probably ovate, higher than wide with a tabulate venter bearing a wide, shallow sulcus. The dense, strong primary ribs pass rursiradiately 
across the umbilical wall and swing gently forward to terminate in slightly elongate tubercles. From these tubercles arise three weaker secondary ribs that are strongly prorsiradiate. The ventral ends of the secondaries are swollen. The ribbing is seen to pass across the ventral sulcus but is much reduced in strength. On the outermost whorl fragment preserved the primaries are a little longer and there appear to be only two secondaries per primary.

A poorly preserved suture line is evident on part of this specimen, suggesting that the body chamber possibly reached a whorl in length (the peristome is not preserved).

Discussion: This specimen differs from species of Arkelloceras (Frebold, 1958; Imlay, 1964b) in having a compressed rather than a depressed or subhexagonal whorl section and in there being no off-set of the ventral ends of the ribs from one side of the sulcus to the other.

This specimen is tentatively assigned to the genus Garantiana because the ribbing is interrupted on the venter by a sulcus, the ribbing is sharp, triplicate to bifurcate and both ventral and lateral tubercles are developed. If the designation is correct, an assignment to the subgenus G. (Garantiana) would be appropriate (Morton, 1971, p. 287). However, this specimen differs from Garantiana in that the zone of furcation is lower on the flanks, the ventral sulcus is wider and the ribs fade markedly as they cross the sulcus as opposed to being entirely interrupted. 
Family PERISPHINCTIDAE Steinmann, 1890

Genus Leptosphinctes Buckman, 1920

Leptosphinctes cf. L. evolutus Imlay

cf. 1964b Leptosphinctes evolutus Imlay; p. B54, pl. 28, figs. 4-6.

1973 Leptosphinctes cf. L. evolutus Imlay; Imlay, p. 91, pl. 47, figs. 21-23, 26, 27 .

Material: Two specimens.

Dimensions: specimen no. $* \mathrm{D}$

U

$\mathrm{Rd}$

u

F 3-64-2

c. 78

c. 41

$--$

22

c. 21

53

* Maximum measurable diameter

Description: This species is represented by two specimens, one of them very poorly preserved (Float 5-14). Specimen F3-64-2 is entirely septate but the outer whorl is crushed. The specimens are extremely evolute with a wide, shallow umbilicus bordered by a rounded umbilical wall. The whorl sides are rounded and the section was probably a little higher than wide before crushing.

All the whorls bear high, slightly prorsiradiate ribs that are interrupted in at least two places, on specimen F3-64-2, by constrictions. None of the ribs appear to bifurcate but the ventral region is generally poorly preserved or inaccessible.

Discussion: These specimens are only compared with $L$. 
evolutus because poor preservation obscures whether or not the ribs on the earlier whorls are tuberculate. Also, rib furcation seems to be absent. In the latter respect, these specimens are similar to $L$. cf. L. evolutus collected from the Snowshoe Formation near Seneca (Imlay, 1973, p. 91). Lep to sphinctes sp.

$$
\text { Pl. 9, fig. } 7
$$

1973 Leptosphinctes sp.; Imlay, p. 91, pl. 47, fig. 24 .

Material: One specimen.

Description: This specimen consists of a fragment of two whorls characterized by their evolute coiling and long, sharp primary ribs that pass prorsiradiately across the whorl sides. Slightly lower and broader secondary ribs arise by furcation and intercalation high on the flanks.

Discussion: This specimen appears to be identical with L. sp. figured by Imlay (Zoc. cit.) which he compares (in some respects) to $L$. (Prorsisphinctes) pseudomartinsi (Arkell, et al., 1957, p. L314, fig. 395).

$$
\begin{gathered}
\text { Procerites ? sp. } \\
\text { Pl. 9, fig. } 6
\end{gathered}
$$

Material: Four fragments.

Discussion: These wretchedly preserved fragments are compressed and show a style of ribbing that compares with 
specimens of Procerites sp. figured by Imlay (1953b, p. 102, pl. 53, figs. 1-3) .

$$
\begin{gathered}
\text { Ammonite gen, and sp. indet. A } \\
\text { PI. 9, fig. } 11
\end{gathered}
$$

Material: One specimen.

Dimensions: Specimen no. $D$ Ud pRd $u$ Wh $W b$

$$
\begin{array}{lllllll}
F 1-22-21 & 104 & 39 & 14 & 38 & 35 & c .37
\end{array}
$$

Description: The specimen retains shell material

(c. $1 \mathrm{~mm}$. thick at $\mathrm{D}=73$ ) and has been slightly crushed in places.

The whorls of the phragmocone, which is less crushed than the body chamber, are ovate in section, wider than high $(\mathrm{Wh} / \mathrm{Wb}=0.8)$. The umbilicus is wide and deep but has probably been widened by preferential crushing of the body chamber. The umbilical wall is high on the phragmocone and steeply inclined at its base but rounding evenly and abruptly into the convex flanks.

The earliest whorls are not visible but the outer whorl of the phragmocone displays coarse, evenly spaced, swollen (almost bullate) primaries that arise very low on the wall and pass rectiradiately across the lower flanks. Fairly low on the flanks, just above the point of maximum inflation, each primary rib becomes associated with two weaker, intercalated secondaries that pass slightly 
prorsiradiately across the upper flank and venter.

On the body chamber, which occupies approximately nine-tenths of the last whorl, the primary ribs are less sharp and the interspaces increase in width slightly to become the same width as the ribs. At diameters greater than $60 \mathrm{~mm}$. the intercalated secondary ribs become less apparent and the ribbing becomes bifurcate and entirely, although slightly, prorsiradiate. The ribbing passes uninterrupted across the somewhat flattened venter. The constricted peristome is preceeded by an unribbed, $8 \mathrm{~mm}$. wide section that displays crowded growth lines.

Discussion: This mature individual has not been satisfactorily identified. It bears some resemblance to Choffatia (Imlay, in litt., 1975) but it is associated with ammonites of undoubted middle Bajocian age. It possibly represents a species of the macroconchiate genus Emeleia. Otoites, the corresponding microconch, is present in the suplee area. Ammonite gen. and sp. indet. B Pl. 9, fig. 8

Material: One specimen.

Description: One tiny whorl fragment from section 1 shows a compressed whorl section bearing a high, wide, flattopped, hollow keel. The upper part of the flank bears sharp ribs, separated by wider interspaces, that project 
strongly onto the venter but do not reach the keel.

Discussion: This is the only ammonite of its kind collected during this study and its affinities are uncertain.

Ammonite gen, and sp. indet. C

P1. 9, fig. 10

Material: Two specimens.

Dimensions: Specimen no.

D Ud Rd

u

$$
\text { F } 1-18-5
$$

13.3

5.2

c. 19

39

Description: These ammonites are characterized by being evolute, having a low, rounded whorl section producing a high, rounded umbilical wall. The sharp, dense, simple ribs arise from high on the umbilical shoulder, pass prorsiradiately to the middle of the flank whence, in a geniculate manner, they become markedly rursiradiate. 


\section{BIBLIOGRAPHY}

ANDALIB, F.

1972. Mineralogy and preservation of siphuncles in Jurassic cephalapods: N. Jb. Geol. Paleont. Abh., 140,1, p. 33-48.

ARKELL, W. J.

1933. The Jurassic System in Great Britain: Oxford, Clarendon Press, $681 \mathrm{p} ., 41$ pls.

1951- Monograph of the English Bathonian ammonites:

1958. London, Palaeontographical Soc., 264 p., 33 pls., 83 text figs.

1956. Jurassic geology of the world: London, oliver and Boyd, 806 p., 46 pls., 28 tables, 102 figs.

ARKELL, W. J., et al.

1957. Mesozoic Ammonoidea, in Moore, R. C., ed., Treatise on invertebrate paleontology, pt. I, Mollusca 4-Cephalopoda, Ammonoidea: New York, Geol. Soc. America, and Lawrence, Univ. Kansas Press, $490 \mathrm{p}$., illus.

BUCKMAN, S. S.

1887- Monograph of the ammonites of the Inferior Oolite

1907. Series: London, Palaeontographical Soc., p. 124, pls. 1-6, 1887; p. 25-56, pls. 7-14, 1888; p. 57-144, pls. 15-23, 1889; p. 145-244, pls. 24-36, 1890; p. 245-256, pls. 37-44, 1891; p. 257-344, pls. 45-76, 1892; p. 345-376, pls. 77-92, 1893; p. 377-456, pls. 93-103, 1894; supplement, p. i-xxxii, pls. I-IV, 1898; p. xxxiii-lxiv, pls. V-XIV, 1899; p. lxv-clxviii, pls. XV-XIX, 1904 ; p. clxix-ccviii, pls. XXXXIV, 1905; p. CCix-cclxii, 1907.

1909- Type ammonites: London, privately published, 1930. v. 1-7, text and 790 pls.

1910. Certain Jurassic (Inferior Oolite) species of ammonites and brachiopoda: Quart, Journ. Geol. Soc., London, v. 66, p. 90-108, pls. 9-12.

BROWN, C. E., and THAYER, T. P. 1966 Geologic map of the Canyon City quadrangle, northeastern Oregon: U. S. Geol. Survey Misc. Geol. Inv. Map I-447. 
BUCH, L. YON

1837. Über den Jura in Deutschland: Abh. kg. Akad. Wiss, Berlin.

CALLOMON, J. H.

1963. Sexual dimorphism in Jurassic ammonites: Leicester Lit. Phil. Soc. Trans., v. 57, p. 21-56.

1964. Notes on the Callovian and Oxfordian Stages: Colloque du Jurassique, Lux., 1962. V. des Comptes Rendus et Mém. publ. par l'Inst. grand-ducal, des Sc. nat. phys. math., p. 269-291, 2 tables.

COLITON, R. K.

1962. Manval of field geology: New York, Wiley \& Sons, 378 N., illus.

COPL, J. C. H. HORTON, A. and TORRENS, H.S.

1969. International field symposium on the Eritish Jurassic: Excursion no. 1, Guide for Dorset and south Somerset: Geology Dept., Keele Univ.

$\operatorname{Cox}, \mathrm{L}, \mathrm{R}$.

1964. The type Bathonian: Colloque du Jurassique, Lux., 1962. Vol. des Comptes Rendus et Mém. pub. par l' Inst. grand-ducal, Sect. des Sc. nat. phys. math., p. 265-268.

CRICKMAY, C. H.

1933. Mount Jura investigation: Geol. Soc. America Bull., v. 44, p. 895-926, pls. 23-34.

DEAN, W. T., DONOVAN, D. T., and HOWARTH, M. K.

1961. The Liassic ammonite zones and subzones of the northwest European province: British Mus.

(Nat. History) Bull., v. 4, n. 10, p. 437-505, pls. 63-75.

DE VILLALTA, J. F., and ROSELL, J.

1966. Estudio de un afloramiento Liasico en el prepirineo de la Provincia de Barcelona: Notas y Comns. Inst. Geol. Min. España, n. 88, p. 7-14, 1 pl.

DICKINSON, W. R.

1958. Geology of the Izee area: unpublished doctoral dissertation, Stanford University. 
DICKINSON, W. R.

1962a. Petrogenic significance of geosynclinal andesitic volcanism along the Pacific margin of North America:

Geol. Soc. America Bull., v. 73, p. 1241-1256, 2 figs.

1962b. Petrology and diagenesis of Jurassic andesitic strata in central Oregon: America.Journ. Sci., v. 260, p. 481-500.

1962c. Metasomatic quartz keratophyre in central oregon: Am. Journ. Sci., v. 260, p. 249-266.

DICKINSON, W. R., and VIGRASS, L. W.

1964. Pre-Cenozoic history of Suplee-Izee district, Oregon:

Implications for geosynclinal theory: Geol. Soc.

America Bul1., v. 75, p. 1037-1044.

1965. Geology of the Suplee-Izee area, Crook, Grant and Harney Counties, Oregon: Oregon Dept. of Geol. and Mineral Industries Bull. 58, 109 p., illus., tables geol. map.

DONOVAN, D. T.

1958. The ammonite zones of the Toarcian (Ammonitico Rosso Facies) of southern Switzerland and Italy: Eclogae Geol. Helvetiae, v. 51, p. 33-60, 4 text figs.

DORN, P.

1935. Die Hammatoceraten, Sonninien, Ludwigien, Dorsetensien und Witchellien des suddeutschen, inbesondere Fränkischen Doggers: Palaeontographica v. 82, Att. A., p. 1-124, pls. 1-29.

ENGEL, R.

1959. Geology of the Lake Elsinore quadrangle, California: California Div. Mines Bull., 146, p. 9-58, 3 pls., 7 text figs.

ERNST, W.

1923. Zur stratigraphie und fauna des Lias zeta in nordwestlichen Deutschland: Palaeontographica, v. 65 , p. 1-95, pls. 1-6.

FREBOLD, H.

1951. Lowermost Middle Jurassic Fauna in Whitesail Lake map-area, British Columbia: in Contributions to the palaeontology and stratigraphy of the Jurassic System in Canada. Geol. Survey Canada, Bull. 18, p. 1-54, pls. 1-18. 
FREBOLD, $\mathrm{H}$.

1953. Correlation of the Jurassic formations of Canada: Geol. Soc. America Bull., v. 64, p. 1229-1246, 1 pl.

1957. The Jurassic Fernie Group in the Canadian Rocky Mountains and Foothills: Geol. Surv. Canada Mem. 287, 197 p., 43 pls.

1958. Fauna, age and correlation of the Jurassic rocks of Prince Patrick Island: Geol. Survey Canada Bull. 41,32 p., 18 pls., 2 tables.

1960. The Jurassic faunas of the Canadian Arctic. Lower Jurassic and lowermost Middle Jurassic ammonites: Geol. Survey Canada 59, 33 p., 15 pls., 1 table.

1964. Lower Jurassic and Bajocian ammonoid faunas of northwestern British Columbia and southern Yukon: Canada Geol. Survey Bull. 1l6, 31 p., 8 pls., l text fig.

1975. The Jurassic Faunas of the Canadian Arctic: Geol. Surv. Canada Bull. 243, 24 p., 5 pls., 1 table.

FREBOLD, H. and TIPPER, H. W.

1967. Middle Callovian sedimentary rocks and guide ammonites from southwestern British Columbia: Geol. Survey Canada Paper 67-21, p. 1-29, pls. 1-3, 2 text figs., 4 tables.

1973. Upper Bajocian-Lower Bathonian ammonite fauna and stratigraphy of Smithers area, British Columbia: Canadian Journ. of Earth Sci., v. 10, n. 7, p. 11091131 , pls. 1-8, 3 text figs., 2 tables.

FREBOLD, H., TIPPER, H. W. and COATES, J. A.

1969. Toarcian and Bajocian rocks and guide ammonites from southwestern British Columbia: Geol. Survey Canada, paper 67-10, 41 p., 6 pls., 4 text figs.

GABILLY, J., ELMI, S., MATTEI, J., and MOUTERDE, R.

1971. Les zones du Jurassique en France: Toarcian: C. R. Somm. Seanc. Soc. geol. Fr., p. 82-84.

GÉCZY, B.

1966. Ammonoides Jurassiques de Csernye, Montagne Bakony, Hongrie. Part I (Hammatoceratidae): Geologica Hungarica (Palaeont.), pt. 35, 282 p., 65 pls.

1967. Ammonoids Jurassique de Csernye, Montagne Bakony, Hongrie. Part II (excl. Hammatoceratidae) : Geologica Hungarica (Palaeont.), pt. 35,413 p.., 65 pls. 
GOTTSCHE, C.

1878. Uber jurassische Versteinerungen aus der Argentinischen Cordillere: Palaeontographica, Supp. 3, Lief. 2, Abt. 3, p. 1-53, pls. 1-8.

GUEX, J .

1972. Répartition biostratigraphique des ammonites

du Toarcien moyen de la bordure sud des

Causses (France) et révision des ammonites

décrites et figurées par Monestier (1931):

Eclogae geol. Helvetiae, v. 65, pt. 3, p. 611-645,

13 pls., 2 text figs.

1973. Observations sur la répartition biostratigraphique

des ammonites du Toarcien superieur de l'Aveyron

(France): Bull. des Lab. de Geol., Min., Geophys.,

Mus. geol. Univ. Lausanne, n. 207, 14 p., pls. 1-2.

1975. Description biostratigraphique du Toarcian supérieur de la bordure sud des Causses (France): Ecolgae Geol. Helvetiae, v. 68, p. 97-129, pls. 1-12, 4 text figs.

HALIAAM, A.

1971. Provinciality in Jurassic faunas in relation to facies and paleogeography in Faunal Provinces in Space and Time (ed. Middlemiss, F. A. and Rawson, P. F.) Liverpool, 236 p., illus.

1975. Jurassic environments: Cambridge, Cambridge University Press, 269 p., illus.

HILTERMANN, $\mathrm{H}$.

1939. Stratigraphie und Palaeontologie der Sonnienschichten von Osnabruck und Bielefeld. I, Teil, Stratigraphie und Ammonitenfauna: Palaeontographica, v. 90, Abt. A., p. 109-212, pls. 9-13.

HIRANO, H .

1973. Biostratigraphic study of the Jurassic Toyora Group, Part III: Trans. Proc. Palaeont. Soc. Japan, N. S., n. 90, p. 45-71, pls. 9-10.

HUDSON, J. D. and PALMER, T. J.

1976. A euryhaline oyster from the Middle Jurassic and the origin of the true Jysters: Palaeontology, v. 19, pt. 1, p. 79-93, pl. 14-15, 1 table, 1 text fig. 
HUF,

1968. Über Sonninien und Dorsetensien aus dem Bajocium von Nordwestdeutschland: Geol. Jahrb: Beihefte, n. 64,126 p., 51 pls., 6 text figs.

IMLAY, R. W.

1945. Jurassic fossils from the southern states, N. 2: Journ. Paleontology, v. 19, n. 3, p. 253-276, pls. 39-41, I fig.

1948. Characteristic marine Jurassic fossils from the western interior of the United States: U. S. Geol. Survey Prof. Paper 214-B, p. 13-33, pls. 5-9.

1953a. Callovian (Jurassic) ammonites from the United States and Alaska, Part I. Western Interior United States: U. S. Geol. Survey Prof. Paper 249-A, p. 1-39, pls. 1-24, 2 text figs., 3 tables.

1953b. Callovian (Jurassic) ammonites from the United States and Alaska, Part II. Alaska Peninsula and Cook Inlet regions: U. S. Geol. Survey Prof. Paper 249-B, p. 41-108, pls. 25-55, 7 text figs., 6 tables.

1955. Characteristic Jurassic mollusks from northern Alaska: U. S. Geol. Survey Prof. Paper 274-D, p. 69-96, pls. 8-13, 1 fig., 4 tables.

1961. Late Jurassic ammonites from the western Sierra Nevada, California: U. S. Geol. Survey Prof. Paper 374-D, p. 1-30, pls. 1-6, 3 text figs, 3 tables.

196la. New genera and subgenera of Jurassic (Bajocian) ammonites from Alaska: Journ. Paleontology, v. 35, n. 3, p. 467-474, pls. 63-64.

1962a. Late Bajocian ammonites from the cook Inlet region, Alaska: U. S. Geol. Survey Prof. Paper 418-A, 15 p., 5 pls, 4 figs, 3 tables.

1962b. Jurassic (Bathonian or early Callovian) ammonites from Alaska and Montana: U. S. Geol. Survey Prof. Paper 374-C, p. 1-32, pls. 1-8, 7 text figs., 6 tables.

1964a. Upper Jurassic mollusks from eastern Oregon and western Idaho: U. S. Geol. Survey Prof. Paper 483-D, 21 p., 4 pls., 3 text figs., 2 tables.

1964b. Middle Bajocian ammonites from the Cook Inlet region, Alaska: U. S. Geol. Survey Prof. Paper 418-B, p. Bl-B61, 29 pls., 5 figs.

1964c. Middle and Upper Jurassic fossils from southern California: Journ. Paleontology, v. 38, p.505-509, pl. 78 . 
IMLAY, R. W.

1967. Twin Creek Limestone (Jurassic) in the western interior of the United States: U. S. Geol. Survey Prof. Paper 540, 105 p., 16 pls., 18 text figs., 12 tables.

1968. Lower Jurassic (Pliensbachian and Toarcian) ammonites from eastern Oregon and California: U. S. Geol. Survey Prof. Paper 593-C, p. ClC51, pls. 1-9, 8 text figs.

1973. Middle Jurassic (Bajocian) ammonites from eastern Oregon: U. S. Geol. Survey Prof. Paper 756, p. 1-100, pls. 1-48, 8 text figs., 10 tables.

1975. Stratigraphic distribution and zonation of Jurassic (Callovian) ammonites in southern Alaska: U. S. Geol. Survey Prof. Paper 836, 28 p., 6 pls., 3 tables, 9 text figs.

IMLAY, R. W. and DETTERMAN, R. L.

1973. Jurassic paleobiogeography of Alaska: U. S. Geol. Survey Prof. Paper 801, 34 p., 15 figs.

JACKSON, K. C.

1970. Textbook of Lithology: San Francisco, McGrawHill, 552 p., illus.

JAWORSKI, E.

1926. La fauna del Lias y Dogger de la Cordillera Argentina en la parte meridional de la Provincia de Mendoza: Actas Acad. Nac. Cienc. Cordoba, v. 9, ns. 3, 4, p. 138-319, pls. 1-4.

JEFFERIES, R. P. S. and MINTON, P.

1965. The mode of life of two Jurassic species of "Posidonia" (Bivalvia): Palaeontology, v. 8, pt. 1, p. 156-85, pl. 19 .

KENNEDY, W. J. and COBBAN, W. A.

1976. Aspects of ammonite biology, biogeography, and biostratigraphy: Palaeontological Association, London. Special Papers in Palaeontology, n. 17, 94 p., 11 pls., 5 tables, 24 text figs.

KOMALARJUN, P. and SATO, T.

1964 Aalenian (Jurassic) ammonites from Mae Sot, northwestern Thailand. Contributions to the the geology and palaeontology of southeast Asia, XIV: Jap. Journ. Geol. Geogr., v. 35, p. 149-161, $1 \mathrm{pl}$. 
LEHMANN, U.

1970. Lias-Anaptychen als kieferelemente (Ammonoidea): Paläont. $\mathrm{z}$., v. $44, \mathrm{n} .1, \mathrm{p} .25-31$.

1971. Jaws, radula, and crop of Arnioceras (Ammonoidea): Palaeontology, v. 14, pt. 2, p. 338-41.

1972. Aptychen als kieferelemente der ammoniten:

Paläont. Z., v. 46, n. 1, p. 34-48.

LEWY, $\mathrm{Z}$.

1972. Xenomorphic growth in ostreids: Lethaia, v. 5, p. 347-352.

LUPHER, R. L.

1941. Jurassic stratigrapy in central Oregon: Bull. of the A. A. P. G., v. 52, p. 219-270.

MARSH, R. C. and MARSH, L. F.

1975. New techniques for coating palaeontological

specimens prior to photography: Journ. Paleontology,

v. 49, n. 3, p. 565-566, 1 text fig.

MAKOWSKI, $\mathrm{H}$.

1963. Problem of sexual dimorphism in ammonites:

Palaeont. Polonica, v. 12, p. 1-92.

MAUBEUGE, P. L.

1951. Les ammonites du Bajocien de la région frontière franco-belge: Inst. Royal Sci. Nat. Belgique

Mém. Sér. 2, fasc. 42,104 p., 16 pls.

1955. Les ammonites aaléniennes, bajociennes et

bathoniennes du Jura suisse septentrional.

Part 1: Schweizer, palaeont. Gesell. Abh.,

v. 71, p. 1-48, pls. 1-11.

MCLEARN, F. H.

1928. New Jurassic ammonoidea from the Fernie Formation, Alberta: Geol. Survey Canada Bull. 49, p. 19-22,

MERLA, G. pls. 4-8.

1933. Ammoniti giuresi dell' Appenino centrale; II Hammatoceratinae: Palaeontogr. Italica, v. 34, p. 1-29, pls. 1-4.

MONESTIER, J.

1921. Ammonites rares ou peu connues et Ammonites nouvelles du Toarcian supérieur du SE de l'Averyron: Mém. Soc. Géol. France, n. 54. 
MORTON, N.

1971a. The definition of standard Jurassic stages: Colloque du Jurassique, Luxembourg, 1967. Mem. B.R.G.M., Fr., n. 75, 1971. Publie par 1' Institut grand-ducal, section des Sciences naturelles physiques et mathematiques, p. 83-93.

1971b. Some Bajocian ammonites from western Scotland: Palaeontology, v. 14, pt. 2, p. 266-93, pls. 40-51.

1972. The Bajocian ammonite Dorsetensia in Skye, Scotland: Palaeontology, v. 15, pt. 3, p. 504-518, pls. 102-105.

1973. The aptychi of Sonninia (Ammonitina) from the Bajocian of Scotland: Palaeontology, v. 16, pt. 1, p. 195-203, pls. 17-18.

1975. Bajocian Sonniniidae and other ammonites from western Scotland: Palaeontology, v. 18, pt. 1, p. 41-91, pls. 6-17.

1976. Bajocian (Jurassic) stratigraphy in Skye, western Scotland: Scottish Journ. Geol., v. 12, pt. 1, p. 21-33, 2 text figs, 1 table.

NEUMAYR, M.

1871. Jurastudien, I. 3 Die Phylloceraten des Dogger und Malm: K. K. Reichsanstalt Jahrb., v. 21 , p. 297-354, pls. 12-17.

OECHSLE, E.

1958. Stratigraphie und Ammonitenfauna der SonninienSchichten des Filsgebiets unter besonderer Berücksichtigung der Sowerbyi-Zone (Mittlerer Dogger, Württemberg): Palaeontographica, v. 111, Abt. A., p. 47-129, pls. 10-20.

ORBIGNY, A. d'

1842- Paléontologie francaise: Terrains jurassiques,

1851. v. 1, céphalopodes: Paris, Masson, 642 p., 234 pls.

PARISCH, C. and VIALE, C.

1906. Contribuzione allo studio delle ammoniti del Lias superiore: Riv. ital. Paleont., p. 141-168, pls. VII-XI.

PARSONS, C. F.

1974. The sauzei and "so called" sowerbyi zones of the Lower Bajocian: Newsletters on Stratigraphy, v. III, n. 3, p. 153-180, 4 figs, 2 tables. 
PETTIJOHN, F. J.

1975. Sedimentary rocks: San Francisco, Harper and Row, 628 p., illus.

PUGIN, L.

1964. Ammonites Prealpines - Etude critique des Lytoceratina du Dogger: Mém. suisses Paléont., v. 80, p. 1-67, pls. $1-4$.

ROMAN, F.

1938. Les ammonites jurassiques et crétacées: Masson (Paris), 554 p., 53 pls., 496 figs.

SAPUNOV, I. G.

1964. Notes on the boundary between the Lower and Middle Jurassic and on the stage term Aalenian: Colloque du Jurassique, Luxembourg, 1962. Volume des Comptes Rendus et Mémoires publié par l'Institut grand-ducal, Section des Sciences naturelles physiques et mathematiques, p. 221-228, 2 tables.

SATO, T.

1954a. Decouverte de Tmetoceras dans le Plateau Kitakami au nord du Japon: Jap. Journ. Geol. and Geog., v. XXIV, p. 115-121, 1 pl.

1954b. Hammatoceras de Kitakami, Japon: Japanese Journ. Geol. Geog., v. 25, p. 81-100, pls. 7-9.

1957. Biostratigraphie de la serie de Shizukawa (Jurassique Inferieur) du Japon Septentrional: Journ. of the Faculty of Sci., Univ. of Tokyo, v. X, pt. III, p. 313-350, pls. 1-2.

1972. Some Bajocian ammonites from Kitakami, northeast Japan: Trans. Proc. Palaeont. Soc. Japan, N. S., n. 85, p. 280-292, pl. 34 .

SCHINDEWOLF, O. H.

1958. Über aptychen (ammonoidea): Palaeontographica Abt. A., 1ll, Liefg. 1-4, p. 1-46.

SETTI, F. L.

1968. Ammoniti del genere Dumortieria nella serie Toarciana del Passo del Furlo (Appennino Centrale): Atti Soc. ital. Sci. nat., v. 107, p. 317-347, pls. 30-32.

SPATH, L. F.

1936. On Bajocian ammonites and belemnites from eastern Persia (Iran): Palaeont. Indica, new ser., v. 22, mem. 3, p. 1-21, $1 \mathrm{pl}$. 
STENZEL, H. B.

1971. Oysters in Moore, R. C. ed., Treatise on invertebrate paleontology, Pt. N., Bivalvia: New York Geol. Soc. America, and Lawrence, University Kansas Press, p. N953-N1224, illus.

STOLL, N. R. (Chairman)

1961. International Code of Zoological Nomenclature adopted by the XV International Congress of Zoology: International Trust for Zoological nomenclature, London.

STURANI, C.

1971. Ammonites and stratigraphy of the Bo sido nia alpina beds of the Venetian Alps (Middle Jurassic, mainly Bajocian): Mem. Inst. Geol. Mineral. Univ. Padova, v. 28, p. $1-190,16$ pls. 46 text figs.

SYLVESTER-BRADLEY, P. C., ed.

1956. The species concept in palaeontology: Systematics Assoc., n. 2, 145 p., illus.

TAYLOR, D. G.

1976. Biostratigraphy of the lower part of the Snowshoe Formation in the Suplee area, Crook, Grant and Harney Counties: Master's thesis in preparation, Portland State University.

WEISERT, K.

1932. Stephanoceras in Schwabischen Braunen Jura Delta: Palaeontographica, v. 76, p. 121-191, pls. 15-19.

WESTERMANN, G. E. G.

1954. Monographie der Otoitidae (Ammonoidea): Beih. geol. Jb., 15, 364 p., 33 pls.

$1964 \mathrm{a}$. The ammonite fauna of the Kialagvik Formation at Wide Bay, Alaska Peninsula. Part I Lower Bajocian (Aalenian): Bull. Amer. Paleont., v. 47, n. 216, p. 325-503, pls. 44-76.

1964b. Sexual-dimorphismus bei ammonoideen und seine bedeutung für die taxionomie der otoitidae (Einschliesslich Sphaeroceratinae; Ammonitina, M. Jura): Palaeontographica, 124A, p. 33-73, pls. 6-9.

1966. Covariation and taxonomy of the Jurassic ammonite So nninia adicra (Waagen): Neues Jahrb. Geologie u. Paläeontologie Abh., v. 124, n. 3, p. 289-312, 10 text figs. 
WESTERMANN, G. E. G.

1969a. Sexual dimorphism in fossil Metazoa and taxonomic implications: Int. Union of Geol. Sciences, Ser. A., n. 1 .

1969b. The ammonite fauna of the Kialagvik Formation at Wide Bay, Alaska Peninsula. Part II. Sonninia sowerbyi zone (Bajocian): Bull. Am. Paleontology, v. 57, n. 255,226 p., 47 pls., 56 text figs.

1971. Form, structure and function of shell and siphuncle in coiled Mesozoic ammonoids: Life Sci. Contr., R. Ont. Mus., n. 78, 39 p., 17 text figs, 1 table.

1975. Bajocian ammonoid fauna of tethyan affinities from the Kambe Limestone series of Kenya and implication to plate tectonics: Newsl. Stratigr., v. 4, p. 23-48, 6 figs, 2 pls., 1 table.

WESTERMANN, G. E. G., and RICCARDI, A. C.

1972. Middle Jurassic ammonoid fauna and biochronology of the Argentine-Chilean Andes, Part I: Hildocerataceae: Palaeontographica, v. $140 \mathrm{~A}$, p. $1-116,31$ pls.

WESTERMANN, G. E. G., and RIOULT, M.

1975. The lectotype of the ammonite Cadomites psil acanthus (Wermbter): Palaeontology, v. 18, pt. 4, p. 871877, pl. 105 .

WHITE, C. A.

1889. On invertebrate fossils from the Pacific Coast: U. S. Geol. Survey Bull. 51, 102 p., illus.

ZITTEL, K. A.

1869. Bemerkungen über Phylloceras tatricum Pusch. sp. und einege andere Phylloceras-Arten:

K. K. Reichsanstalt Jahrb., v. 19, p. 59-68, $1 \mathrm{pl}$. 
PLATES

All figures are natural size. All specimens were coated with sublimate of ammonium chloride prior to photography (see Marsh and Marsh, 1975). The plate explanations list the following information after the name of the fossil: hyfotype number (= specimen number, see Appendix C); stratigraphic position above the base of the Snowshoe Formation in feet followed by the metric equivalent in parentheses; member from which the specimen was collected; age of the specimen; page where systematic description is located.

\section{Plate 1}

Figures

1. Phy Zloceras kunthi ? Neumayr.

F2-17-2; 159 (48.5); lower; lower Bajocian; p. 69 .

2, 3. Phy Zloceras sp.

2. F5-4-3; $229(69.8)$; lower; middle Bajocian (Sauzei Zone); p. 70 .

3. Float 2-52; float; middle?; middle Bajocian? p. 70 .

4. Holcophylzoceras costisparsum Imlay. F5-3-3; 220 (67.1); lower; lower Bajocian; p. 71 .

5. Lytoceras aff. L. eudesianum (d'Orbigny). F5-5-12; 350 (106.7); lower; midale Bajocian (Sauzei Zone); p. 74 .

6. Lytoceras espinazitum Pugin. F5-4-23; 229 (69.8) lower; midale Bajocian; p. 73 . 
7. Pseudolioceras cf. P. spitsbergense Frebold. F4-4-22; 123 (37.5); lower; upper Toarcian (Levesquei Zone); p. 74.

8-10. Polyplectus spp.?

8. F4-3-13; $68(20.7)$; lower; upper Toarcian (Levesquei Zone); p. 77.

9. F4-3-61; $97(29.6)$; as for figure 8 . 10. F4-3-9; as for figure 8 .

11-14. Grammoceras s. 2 .

1.1. F5-1-0; $11(3.4)$; lower; upper Toarcian; p. 79 .

12. F4-4-17; 123 (37.5); lower; upper Toarcian (Levesquei zone) i p. 79.

13. F4-3-165; 109 (33.2); as for figure 12 .

14. F4-3-123; $106(32.3)$; as for figure 12 .

15, 16. Dumortieria raricostata Géczy.

15. F4-3-138; 108 (32.9); lower; upper Toarcian (Levesquei Zone); p. 83.

16. Ventral view of same specimen.

17. Dumortieria insignisimilis (Brauns). F4-4-14; $123(37.5)$; lower; upper Toarcian (Levesquei Zone); p. 81.

18. Dumortieria Cf. D. exacta Buckman. F4-4-38; $123(37.5)$; lower; upper Toarcian (Levesquei Zone); p. 88.

19. Dumortieria cf. D. dumortieri Thiollière. F4-4-88; 131 (39.9); lower; upper Toarcian (Levesquei Zone); p. 87.

20-22. Dumortieria ? cf. D. pusizla Jaworski. 20. F5-1-4; 51 (15.5); lower; upper Toarcian; p. 91 .

21. F4-4-2; $123(37.5)$; lower; upper Toarcian (Levesquei Zone); p. 91. 22. F4-4-41; as for figure 21 . 


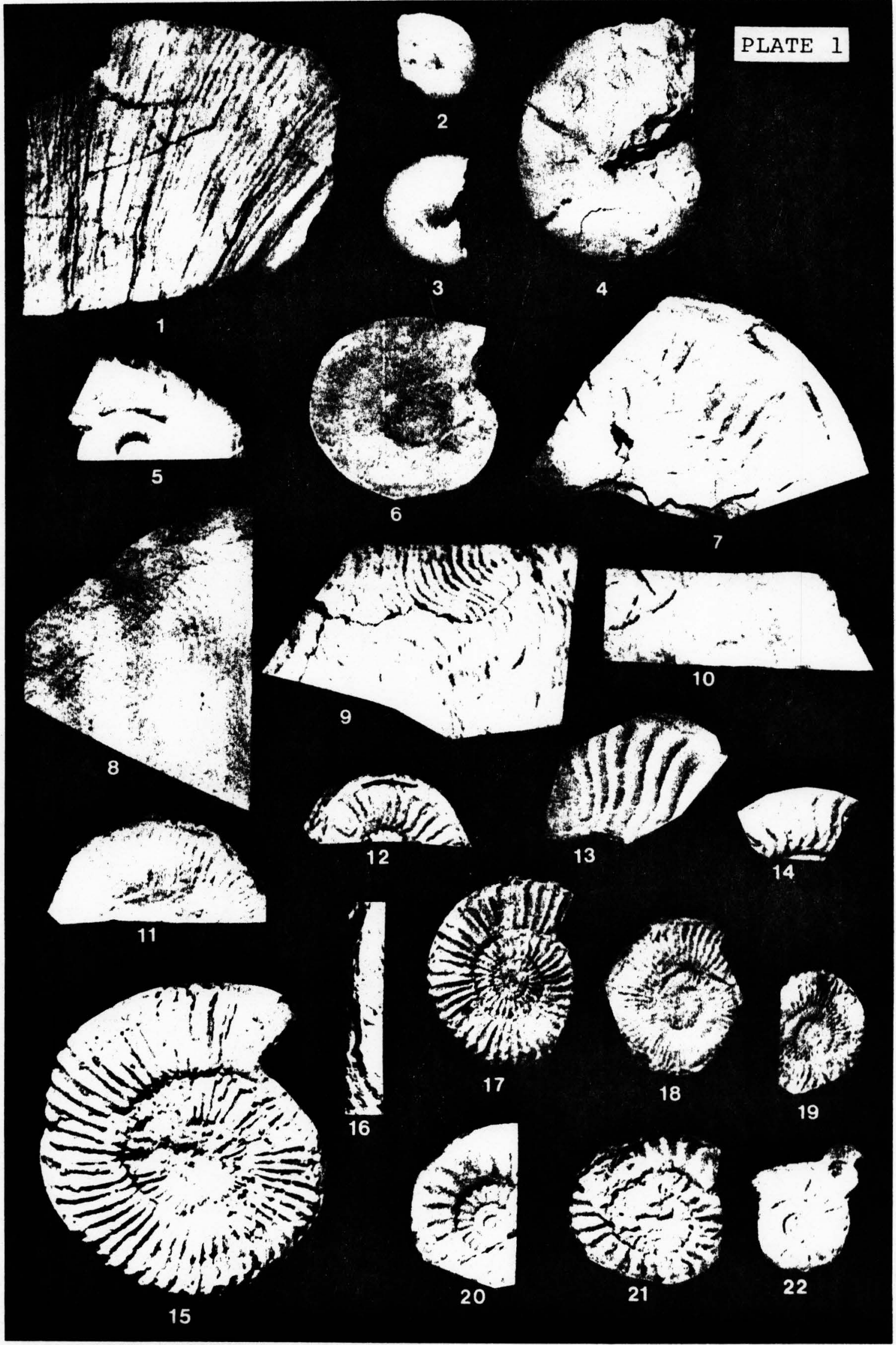


Plate 2

Figures

1. 2. Tmetoceras scissum (Benecke).

1. F4-5-3; $188(57.3)$; lower; lower Bajocian; p. 94 .

2. F2-7-1; $107(32.6)$; as for figure 1 .

3. 5. Hammatoceras spp.

3. F4-4-25; $130(39.6)$; lower; upper

Toarcian (Levesquei Zone); p. 98.

5. F4-4-28; as for figure 3 .

4. Hammatoceras speciosum Janensch.

F4-4-39; $123(37.5)$; lower; upper

Toarcian (Levesquei Zone); p. 97.

6-9. Planammatoceras ? spp.

6. F2-19-43; 169 (51.5); lower; lower

Bajocian (Murchisonae Zone ?); p. 100.

7. F2-19-93; as for figure 6 .

8. F2-12-20; 151 (46); as for figure 6 .

9. F2-19-67; as for figure 6 .

10. Witchellia connata (Buckman).

F3-3(1-33; $300(91.4)$; lower; micidle

Bajocian (Laeviuscula Zone); P. 107.

1.1. Witchellia spp.

F2-52-53; float; micile?; midale

Bajocian ; p. 108 .

12. Witchellia (Latiwitchellia) evoluta Imlay.

F3-30-68; $304(92.7)$; lower; middle

Bajocian (Laeviuscula Zone); p. 109. 


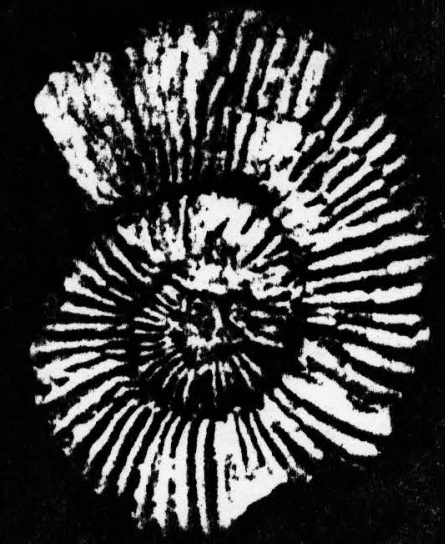

i. 41019

in $x(y)+5$

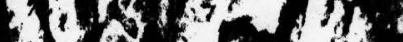
- I $\%$ (1) $14,3 y$

C $x+1,1$ af 1 की sis 91 lof

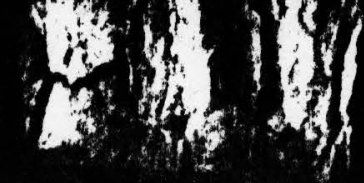

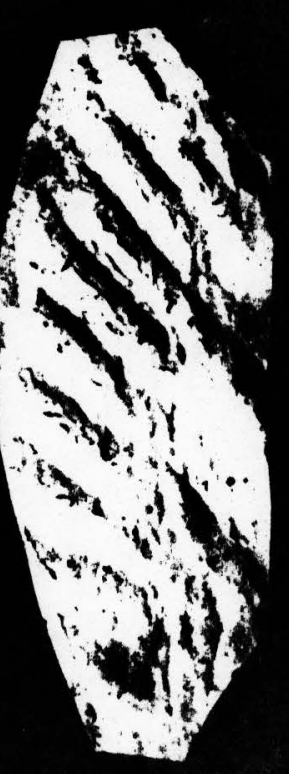

9

10

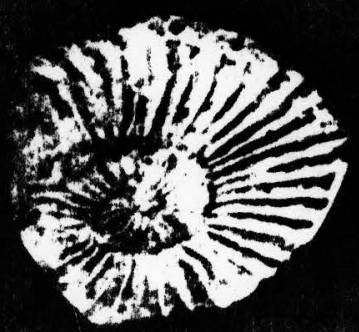

2
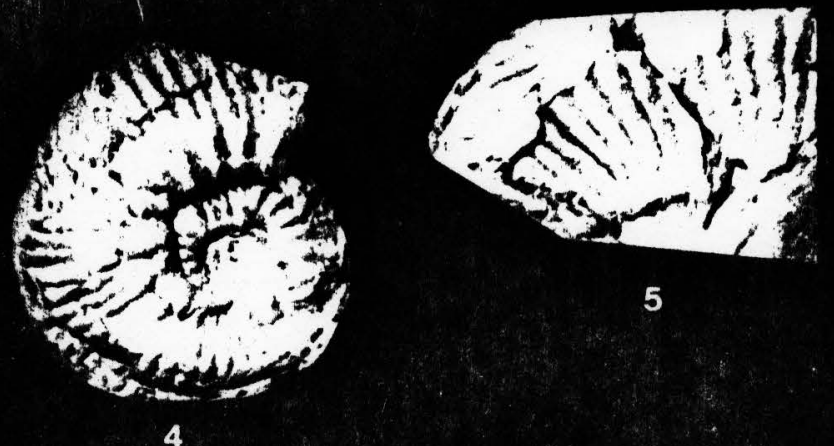

5

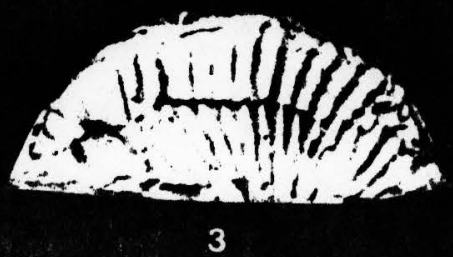

PLATE 2

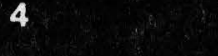

$x^{2}+\frac{x}{5}$
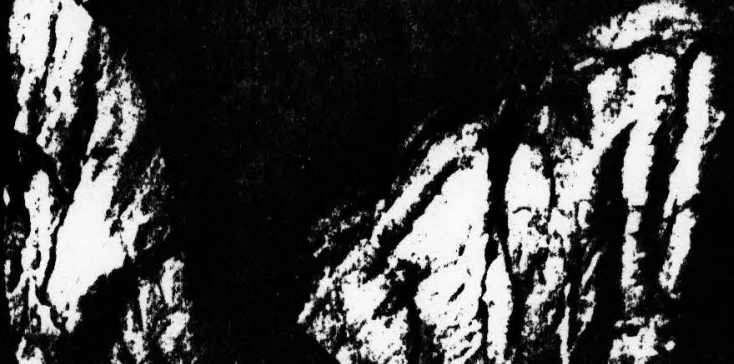

(2) by

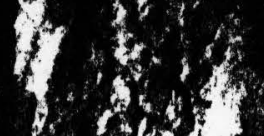

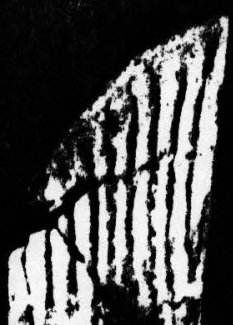

1.t. th

(1) 1

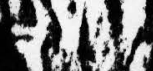

(. 747

8 is?

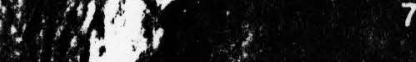

(x): $: 4$

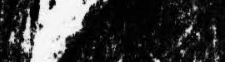

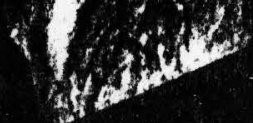
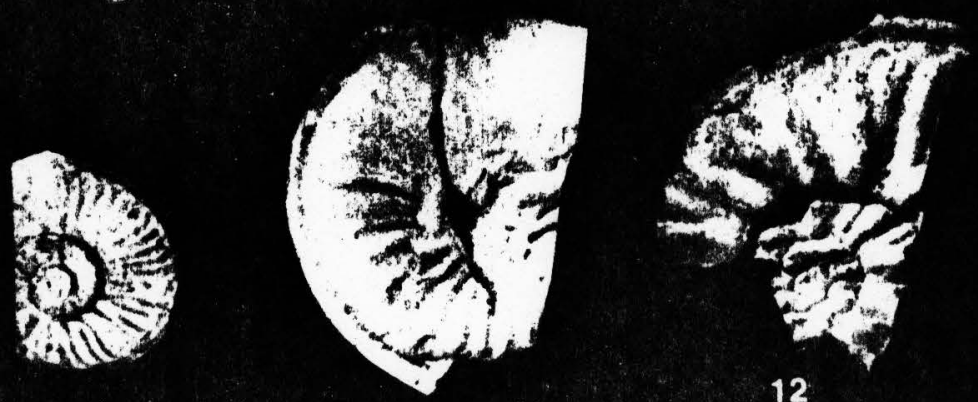

12 
Plate 3

Figures

1. Sonninia sp.

F1-22-22; 1055 (321.6); middle;

midale Bajocian (Sauzei Zone); p. 103.

2. Sonninia (Euhoploceras) spp.

A-0756; 240 (73.2); lower; midale

Bajocian (Discites Zone); p. 106.

3, 4, 6. Sonninia (Papilliceras) spp.

3. F3-17-29; 375 (114.3); lower; midale Bajocian (Sauzei Zone); p. 104.

4. F3-30-243; $368(112.2)$; as for figure 3 .

6. F3-17-80; 374 (114); as for figure 3 .

5. Aptychus.

Associated with specimen F3-17-29

(figure 3).

7. Dorsetensia ? sp.

F5-4-93; 290 (38.4); lower; middle

Bajocian (Sauzei Zone); p. 120.

8. Sonninia cf. S. nodatipinguis (Buckman). F5-5-199; 386 (117.7); lower; micldle Bajocian; p. 102 . 

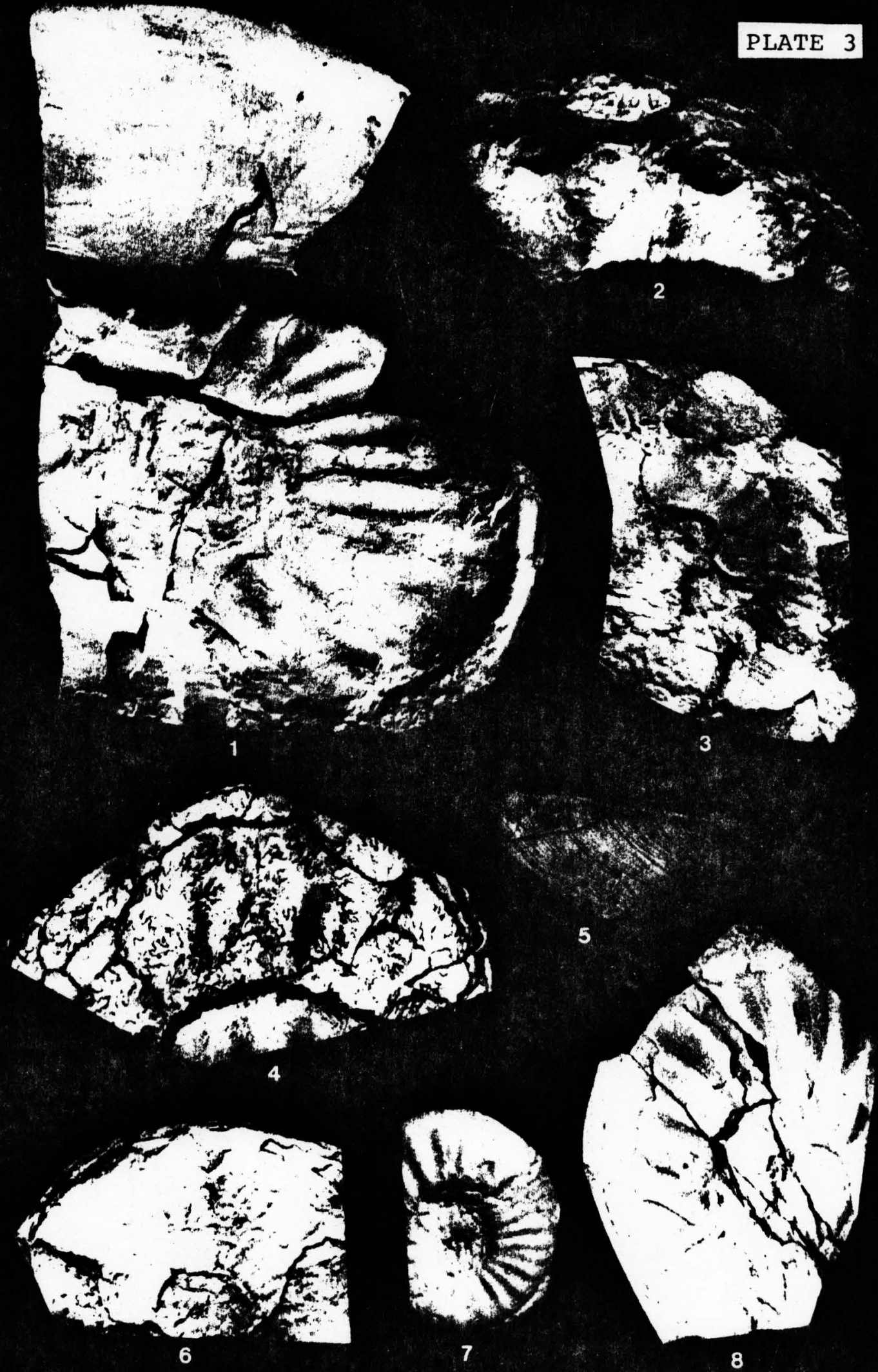
Plate 4

Figures

1. Dorsetensia edouardiana (d'Orbigny).

F3-31-170; 427 (130.1); lower; middle Bajocian (Humphriesianum zone); p. 111.

2, 3. Dorsetensia oregonensis Imlay.

2. F3-31-147; 397 (121); lower; middle Bajocian (Sauzei Zone); p. 112 .

3. F3-31-84; 391 (119.2); as for figure 2 .

4, 7, 8. Dorsetensia romani (Oppel).

4. F3-30-3; 295 (89.9); lower; middle Bajocian (Laeviuscula Zone); p. 115 .

7. F'3-30-345; 381 (116.1); lower; middle Bajocian (Sauzei Zone); p. 115 .

8. F3-31-108; $393(119.8)$; as for figure 7 .

5, 6. Dorsetensia pinguis (Roemer).

5. F5-5-11; $350(106.7)$; lower; middle Bajocian (Sauzei Zone); p. 113.

6. F3-31-86; $390(118.9)$; as for figure 5 .

9, 10. Dorsetensia cf. D. subtecta Buckman.

9. CAS 13430 (see Imlay, 1973).

10. F5-4-90; 290 (88.4); lower; middle Bajocian (Sauzei Zone); p. 116 .

11. Dorsetensia sp. A.

CAS 13442 (see Imlay, 1973). 


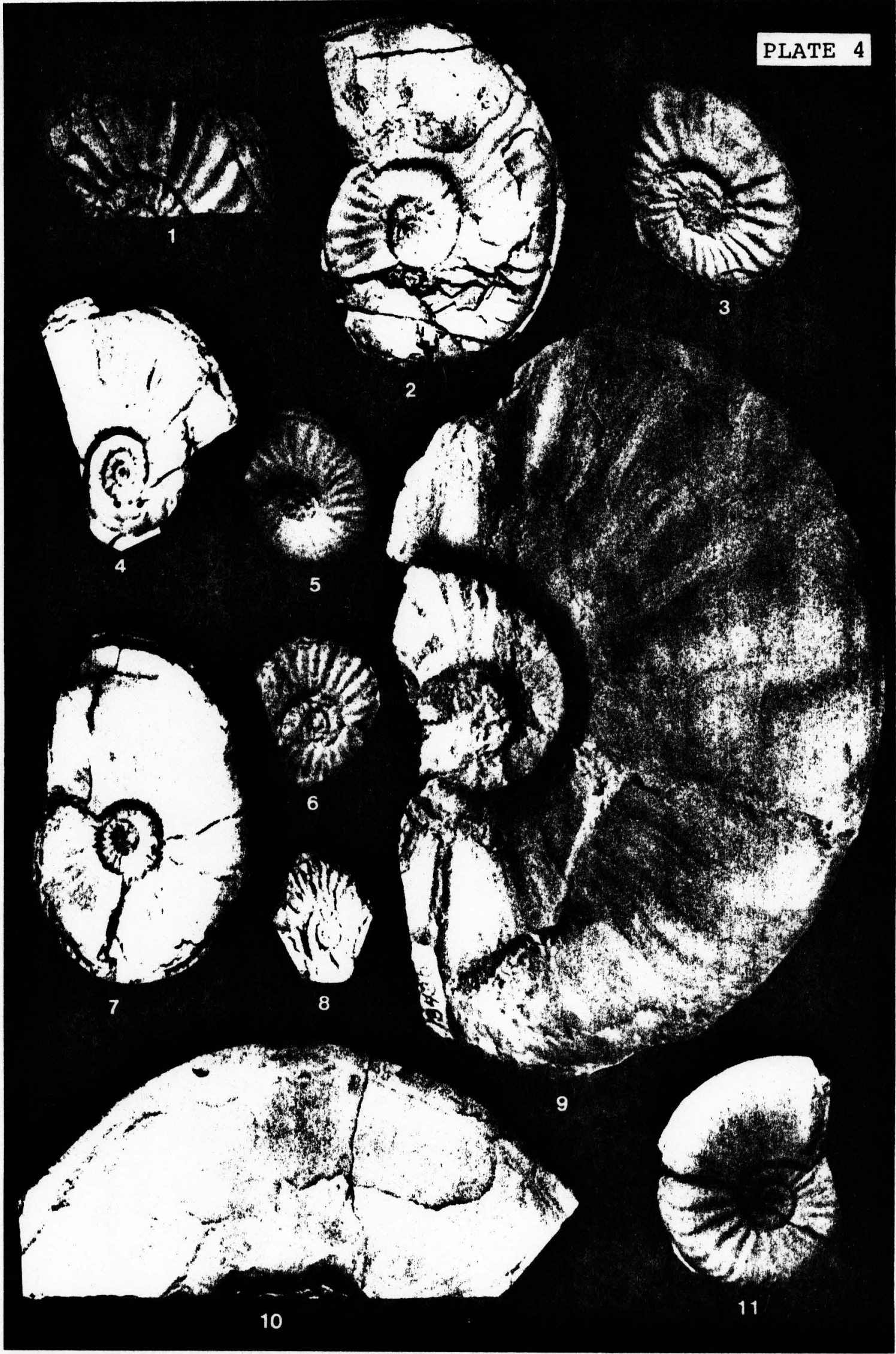


Plate 5

Figures

1, 2. Dorsetensia sp. B.

1. F3-31-149; 396 (120.7); lower; middle Bajocian (Sauzei Zone); p. 119 .

2. Float 5-3-2.

3. Pelekodites Cf. P. zurcheri (Douvillé). F5-5-1; $324(98.8)$; lower; middle Bajocian (Sauzei Zone); p. 123.

4, 5. Pelekodites silviesensis Imlay.

4. F5-5-106; $383(116.7)$; lower; middle Bajocian (Humphriesianum Zone?); p. 121 .

5. F5-4-60; $272(82.9)$; lower; middle Bajocian (Sauzei Zone); p. 121.

6. Pelekodites dobsonensis Imlay. F3-31-35; 387 (118); lower; middle Bajocian (Sauzei Zone); p. 122 .

7. Poecizomorphus varius Imlay. F3-31-185; 428 (130.5); lower; middle Bajocian (Humphriesianum Zone); p. 126 .

8. Strigoceras cf. S. Zanguidum (Buckman). F5-5-11; 350 (106.7); lower; middle Bajocian; p. 127 .

9, 10. Lissoceras hydei Imlay.

9. F3-30-82; 306 (93.3); lower; midale Bajocian (Laeviuscula Zone); p. 128.

10. F3-17-92; 373 (113.7); lower; middle Bajocian (Sauzei Zone); p. 128 .

11, 12. Oppelia subradiata? (J. de C. Sowerby). 11. F5-5-194; 386 (117.7); lower; middle Bajocian (Humphriesianum Zone); p. 129 .

12. F5-5-67; $366(111.6)$; as for figure 11 .

13. Oecotraustes sp.

U. Sn. Loc. A., 2 (Locality E of this report); 450 feet (137.2) below the top of the Snowshoe Formation in the upper member; p. 130. 
14. Normannites (Normannites) orbignyi Bucknan. F3-39-7; 1045 (318.5); micidle; upper Bajocian; p. 131 .

15-17. Normannites cf. N. vigorosus (Imlay).

15. F3-38-49: 1029 (313.6); midale; upper Bajocian; p. 132 .

16. F3-38-4; $1023(311.8)$; as for ficure 15.

17. F3-38-11; as for figure 15 .

18. Normannites sp.

F3-32-7; 487 (148.4); lower;

midale Bajocian (Humphriesianum

Zone); p. 134 . 

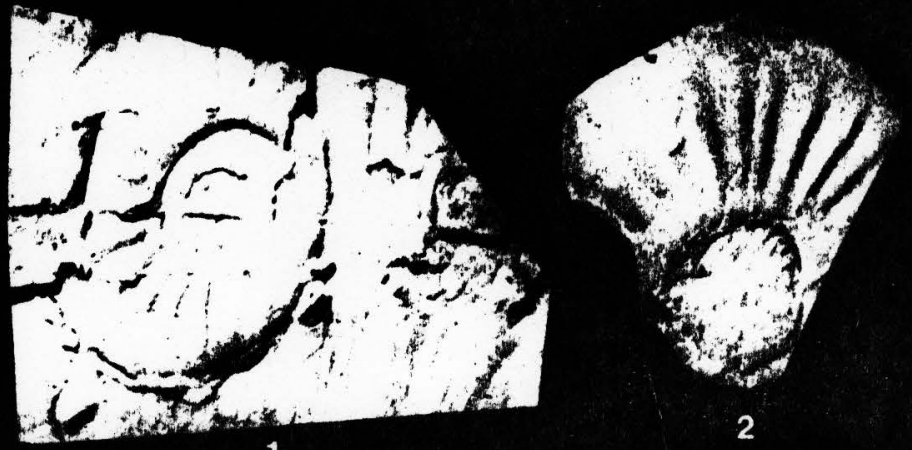

PLATE 5

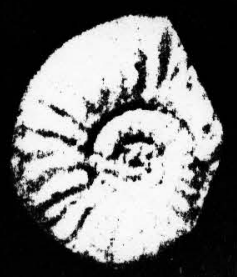

4

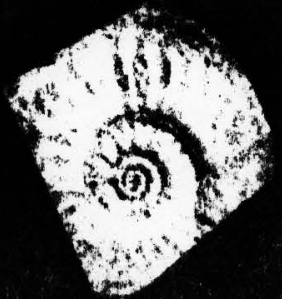

5

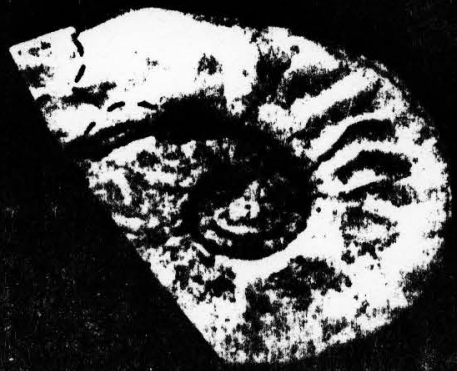

6

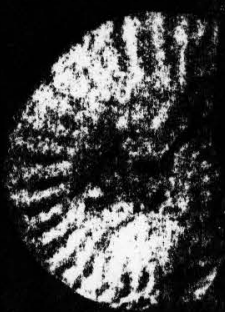

8

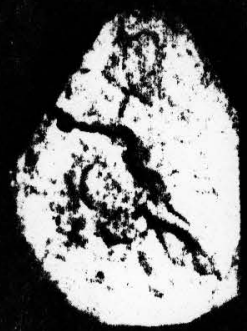

9

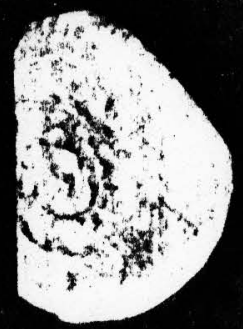

10

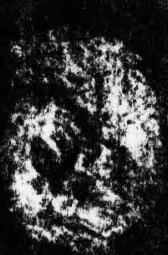

11

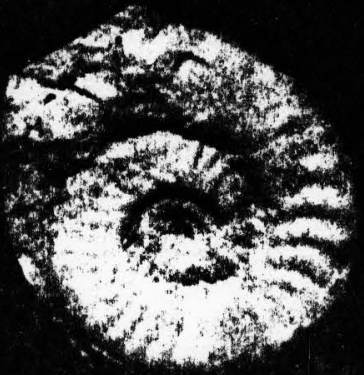

3
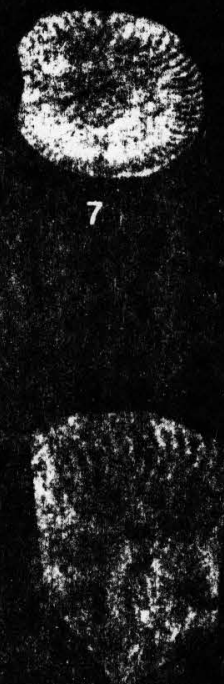

12

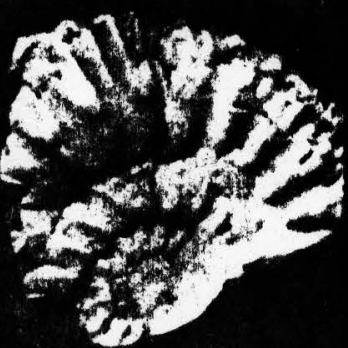

16

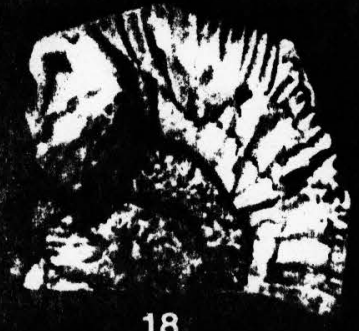




\section{Plate 6}

rigures

1, 3. Stephanoceras nodosum (Quenstedt).

1. F5-5-103; 383 (116.7); lower; middle Bajocian (Humphriesianum Zone); $\mathrm{F} .134$.

3. F3-30-322; $378(115.2)$; lower; midale Bajocian (Sauzei Zone); p. 134 .

2. Stephanoceras sp. A.

F6-1-31; Locality G; Silvies;

midale Bajocian (Humphriesianum zone); p. 136 .

4. Stephanoceras (Skirroceras) juhlei Imlay. F3-31-1; 386 (117.7); lower; midale Bajocian (Sauzei Zone); p. 139 .

5. Stephnanoceras (Skirroceras) aff.

S. (S.) juhlei Imlay.

F3-35-14; 762 (232.3); middle; middle

Bajocian (Humphriesianum Zone);

p. 142 .

6, 8. Stephanoceras spp.

6. F 3-30-377 (1); 382 (116.4); lower; middle Bajocian (Sauzei Zone); p. 137.

8. F3-31-159; 420 (128); as for ficure 6 .

7. Stephanoceras n. sp. ?

F3-38-71; 1026 (312.7); middle;

upper Bajocian; p. 137.

9. Stephanoceras (Skirroceras) kirschneri Imlay. F3-31-265; 447 (136.2); lower; midale Bajocian (Humphriesianum zone); p. 143. 

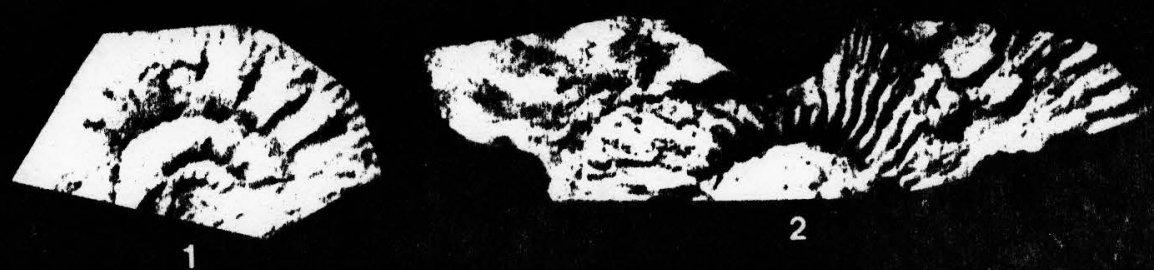

PLATE 6
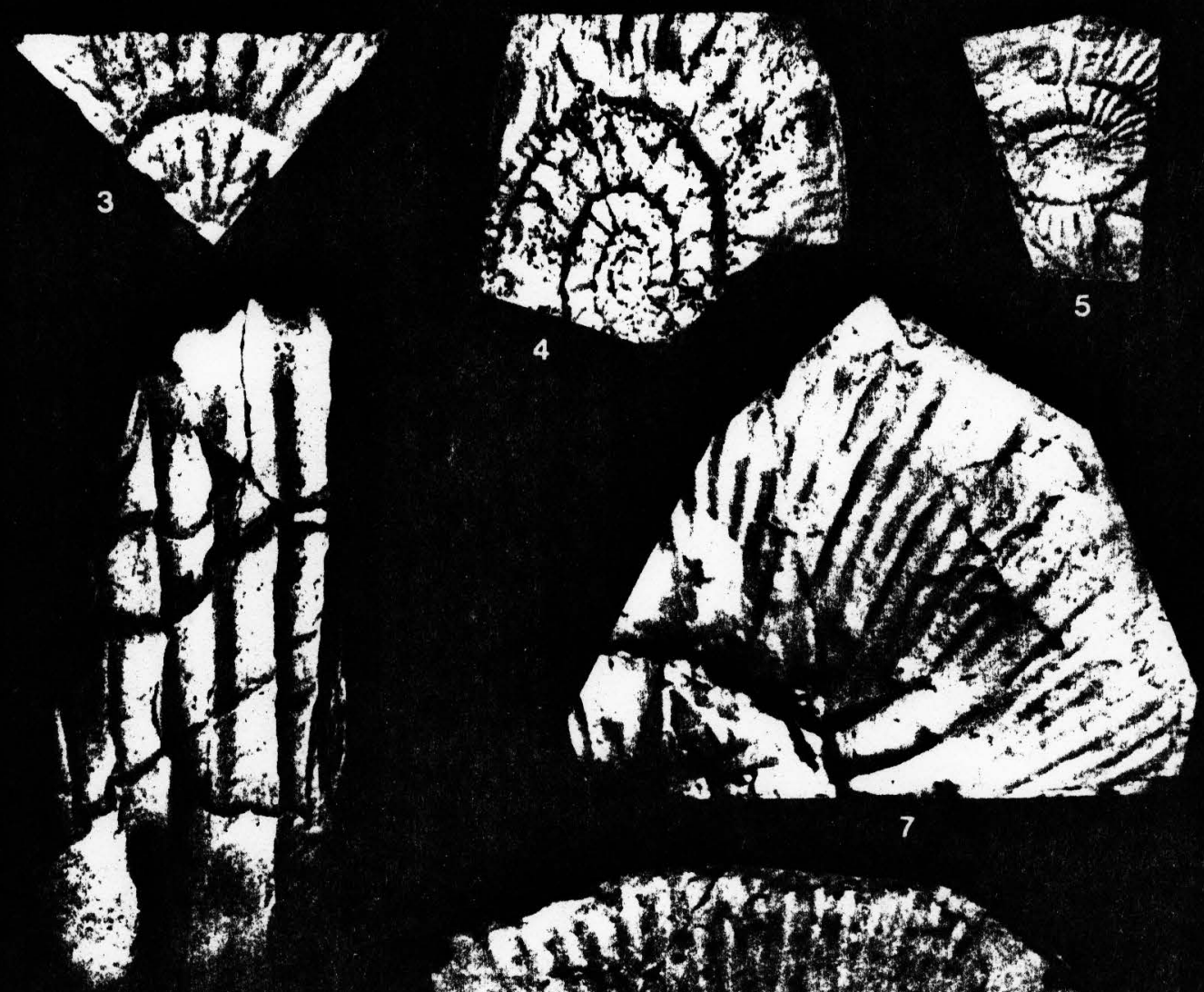

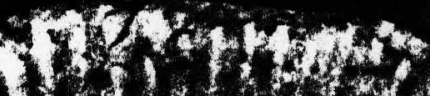

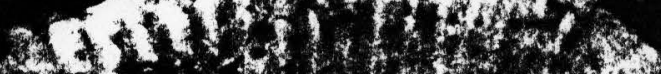

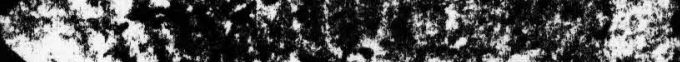

6

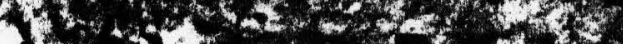

$\therefore$ (1)

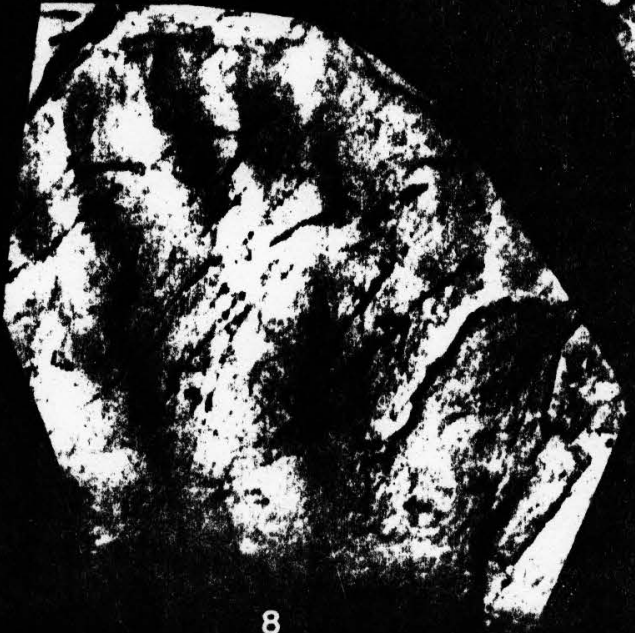

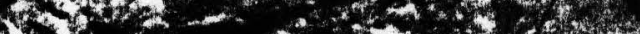

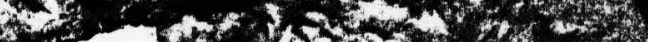

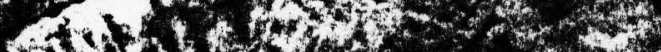

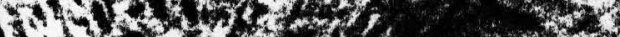

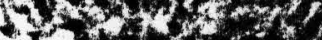

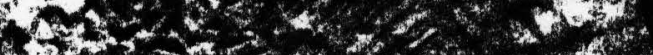

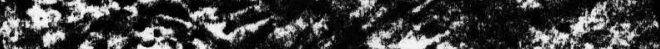

T.t.

$15 x+3 x+2$

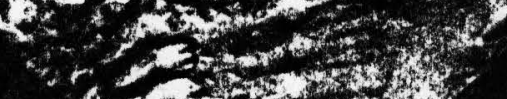

9

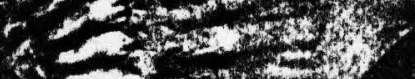

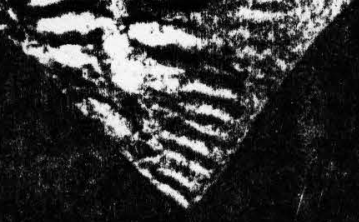


Plate 7

Iigures

1. Stephanoceras (Skirroceras) juhlei Inlay. F1-21-31; 1134 (345.6); niddle; middle Bajocian (Sauzei Zone); p. 139 . 


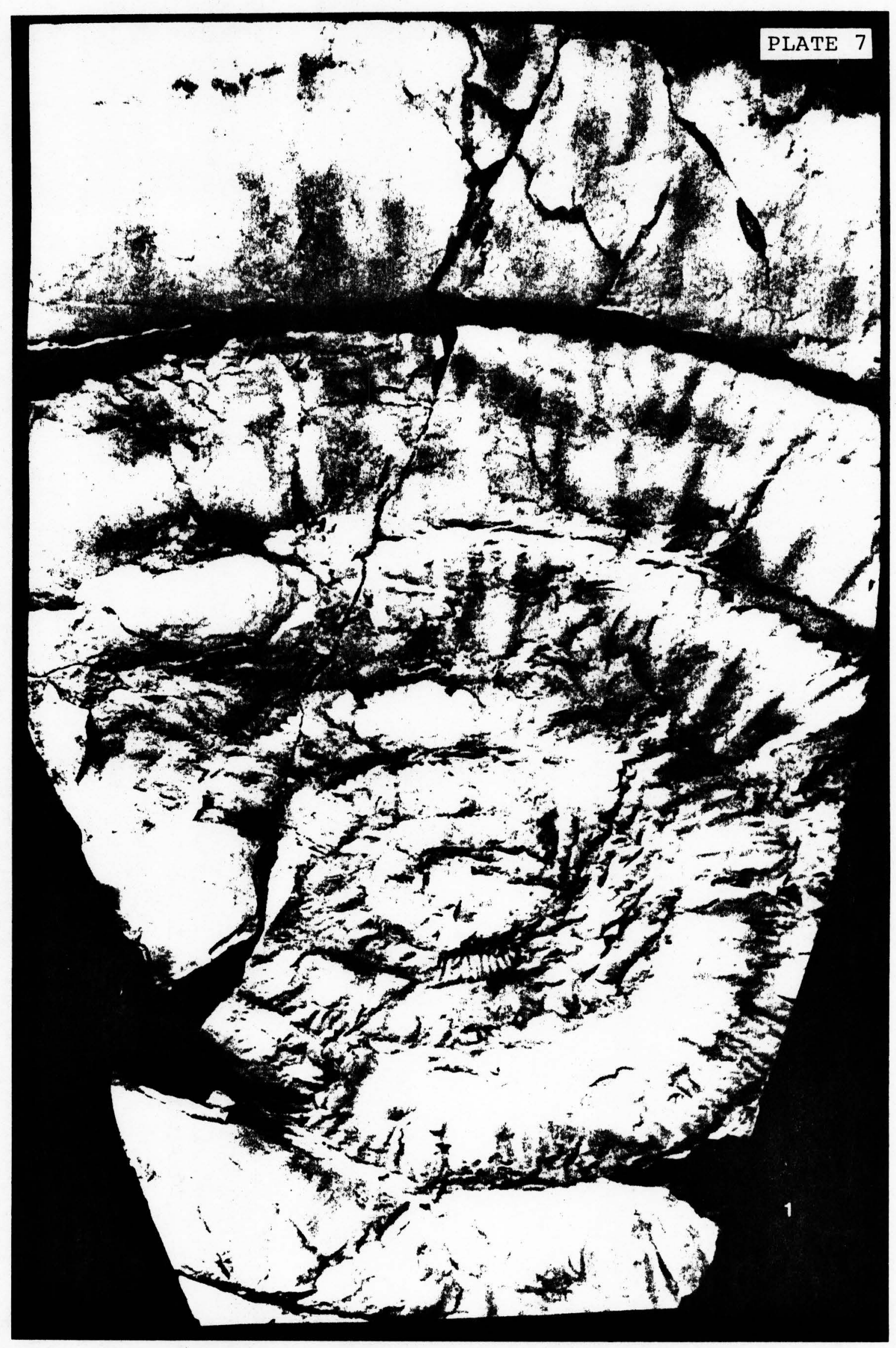


Plate 8

Figures

1. Stemmatoceras aff. S. albertense McLearn. F3-35-40 (4); 768 (234.1); middle; middle Bajocian (Humphriesianum Zone); p. 143 .

2. Stemmatoceras sp. F6-1-2 (ventral view); Locality G; Silvies; middle Bajocian (Humphriesianum Zone); p. 145 .

3, 4. Cadomites ? sp.

3. F3-35-7; $715(217.9)$; middle; midale Bajocian (Humphriesianum Zone); p. 146 .

4. $\mathrm{F} 3-35-7(2)$; as for figure 3 .

5, 6, 8. Lupherites senecaensis Imlay.

5. F6-1-19; Locality G; Silvies; middle Bajocian (Humphriesianum Zone); p. 148 .

6. F6-1-9 (lateral lappet); as for figure 5 .

8. F6-1-1; as for figure 5 .

7. Sphaeroceras sp.

F3-35-4I (3); 770 (234.7); midāle;

micidle Eajocian (Humphriesianum

Zone); f. 152 .

9. Chondroceras alzani (McLearn).

F'3-35-58; 779 (237.4); middle;

middle Bajocian (Humphriesianum

Zone); F. 150 .

10. Buzzatimorphites ? $\mathrm{sp}$.

F5-14-36; 1768 (538.9); upper;

lower Callovian; p. 153.

11-13. Xenocephalites vicarius Imlay.

11. F5-14-6; 1768 (538.9); upper;

lower Callovian; p. 154.

12. F5-14-68 (2); as for figure 11.

13. $15-14-84(2,3)$; as for figure 11 .

14. Lizloettia lizloetensis Crickmay. F5-14-31; 1768 (538.9); upper;

lower Callovian; p. 155. 
rigures

15. Lizloettia mertonyarwoodi ? Crickmay. F5-14-1; 1718 (523.6); upper;

lower Callovian; p. 157.

16. Lizloettia buckmani (Crickmay). F5-14-27; 1768 (538.9); upper; lower Callovian; p. 156. 
4

1

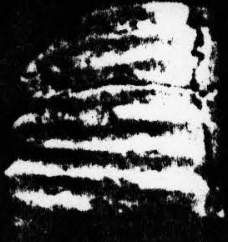

2

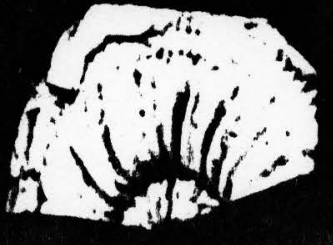

3

PLATE 8

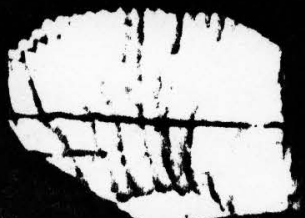

4

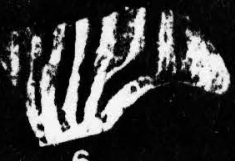

(1)1 1)

21.

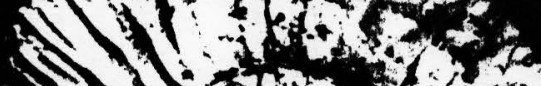

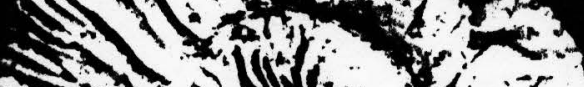

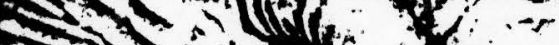

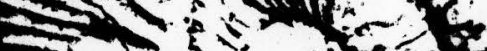

$=1-5$

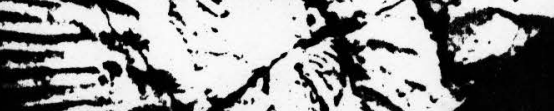

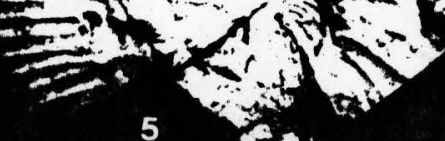

5 is
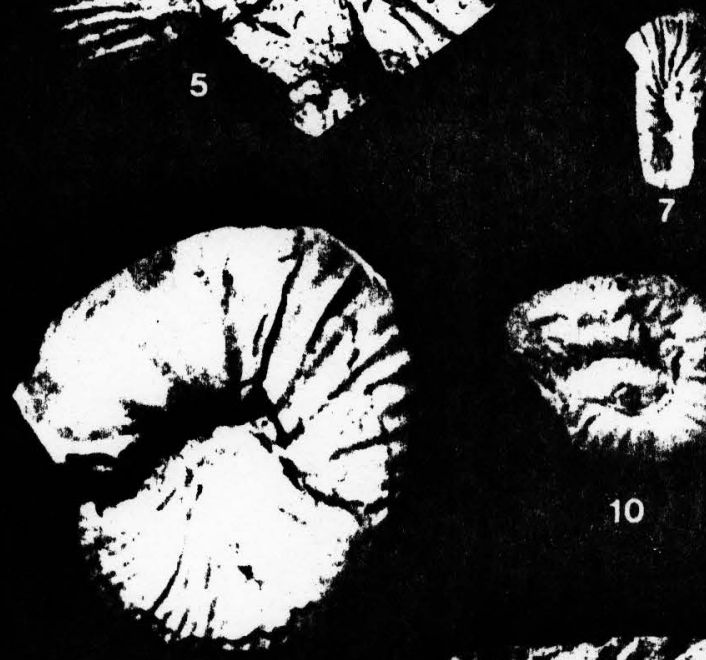

7
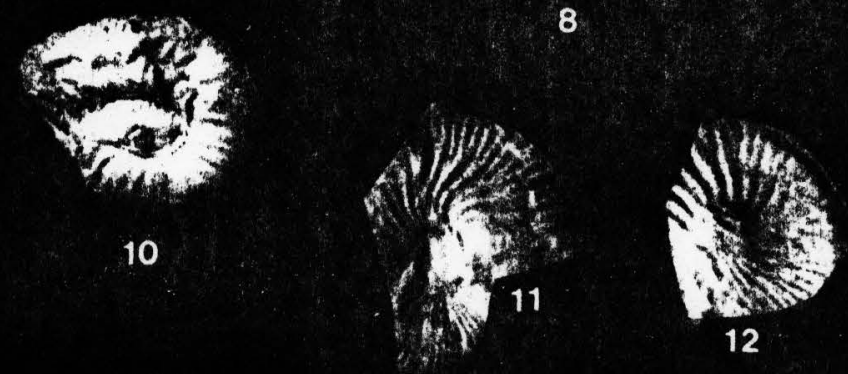

9

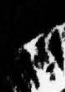

(11) Pin

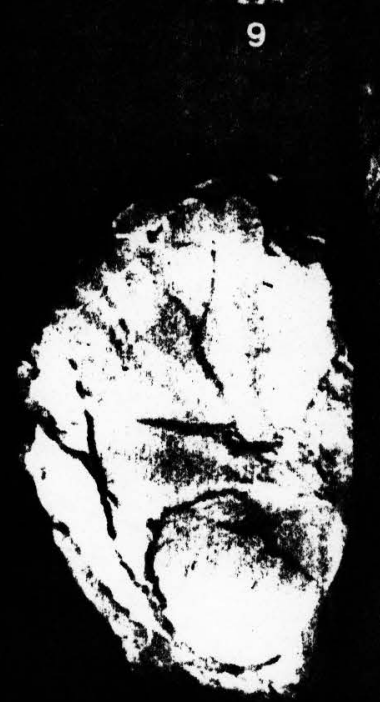
11rotion.

tow

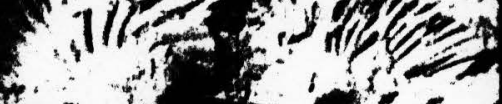

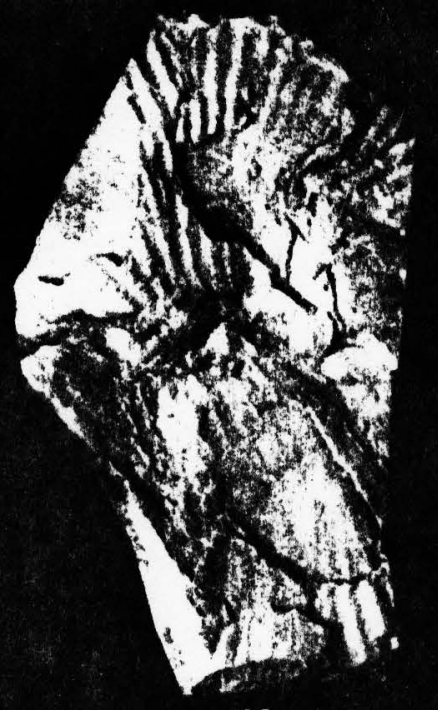


Plate 9

I'igures

1, 2. Kepplerites spinosum (Inilay).

1. U. Sn. I,OC. A (Locality E of this report); float; upper?; lower Callovian; p. 157.

2. Ventral view of an inner whorl of same specimen.

3 , 4. Garantiana?

3. F 3-38-21; 1026 (312.7); niddle; upper Bajocian; p. 158.

4. Ventral view of same specimen.

5. Leptosphinctes cf. L. evolutus Imlay. F3-64-2; 3114 (949.2); upper;

upper Bajocian; p. 160.

6. Procerites ?

F5-13-2; 1551 (472.7); upper;

lower Callovian; p. 161 .

7. Leptosphinctes sp.

F3-63-1; 2089 (CI1); upper;

upper Bajocian; p. 161 .

Q. Ammonite gen. and $\mathrm{sp}$. indet. $\mathrm{B}$.

F1-10-4 (1); 1399 (42.6.4); middle;

p. 163 .

9. Gastropod gen. and sp. indet.

Locality $D$; Silvies?

10. Anmonite gen. and sp. incet. C.

Fl-18-5; 1399 (426.4); middle;

p. 164 .

11. Ammonite gen. and sp. indet. A. Fl-22-2l; 1064 (324.3); middle; middle Bajocian (Sauzei Zone); F. 162 .

12. Camptonectes sp.

F5-5-13; $350(106.7)$; lower;

middle Bajocian (Sauzei Zone). 
APPENDIX A

SECTION AND LOCALITY DESCRIPTIONS

All locality information refers to the United States Department of Agriculture (Forest Service) Izee quadrangle (number 325) unless otherwise stated.

Measured Sections (see fig. 1 and figs. 6 to 10).

Section 1 (Big Flat): From the Big Flat triangulation

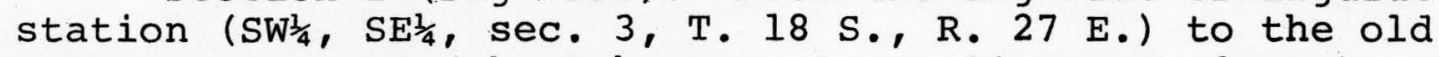

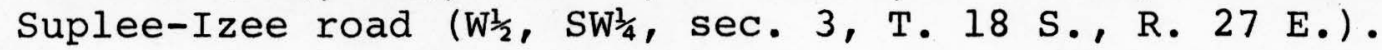

Section 2 (Flat Creek): From the right angled bend in Flat Creek (SW $\frac{1}{4}, S^{\frac{1}{4}}$, sec. 10, T. 18 S., R. 27 E.) along the creek to the $\mathrm{NW}^{\frac{1}{4}}, \mathrm{NW}^{\frac{1}{4}}$, sec. 15, T. $18 \mathrm{~S} ., \mathrm{R}, 27 \mathrm{E}$.

Section 3 (Bunton Hollow): Along the Forest Service road from the headwaters of Rosebud Creek (NE $\frac{1}{4}, \mathrm{SW}_{\frac{1}{4}}$, sec. 1, T. $17 \mathrm{~S} ., R_{0} 28$ E.) to the eastern bank of Lewis Creek (SW $\mathrm{SE}_{\frac{1}{4}}, \mathrm{sec} .6, \mathrm{~T} .17$ S., R. 29 E.).

Section 4 (Sheep Creek Divide): From a road-cut in the headwaters of a tributary of Sheep Creek, southwest

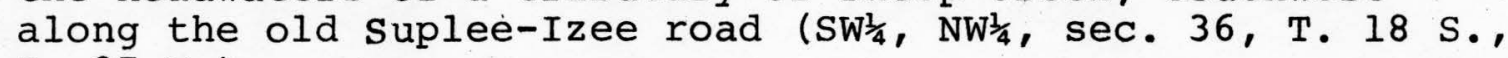
R. 27 E.).

Section 5 (Caps Creek): Along the lower reach of Caps

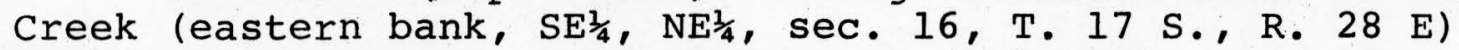
to the eastern bank of Rosebud Creek (NW $\frac{1}{4}, \mathrm{SW}_{\frac{1}{4}}, \mathrm{sec} .15$, T. 17 S., R. 28 E.).

Localities (see fig. 1).

Locality A: In the stream bed of Flat Creek approximately 80 feet (c. 24 meters) upstream from where the first main tributary flowing past the Bush Mill site enters Flat

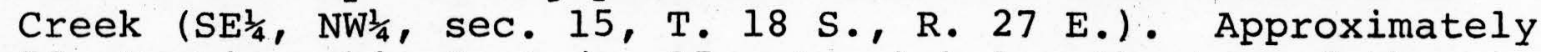
50 stratigraphic feet (c. 15 meters) below the top of the Formation in the middle member. Specimens collected from 
this locality are marked "F2-52". For purposes of the check list (Table II), Localities $A$ and $B$ are treated as one.

\section{Locality B: Lupher's locality L128}

on the east side of Flat Creek, 100' above stream bed, and 250 yards N. $25^{\circ}$ W. from mouth of first main tributary that comes into Flat Creek from the west below Big Flat, probably south central part of NW $\frac{1}{4}$, sec. 15, T. $18 \mathrm{~S}$, R. $27 \mathrm{E}$.

(Imlay, 1973, p. 50). Approximately 60 stratigraphic feet (c. 18 meters) below the top of the Formation in the middle member. For the purposes of the check list (Table II), Localities A and B are treated as one.

Locality C: Lupher's locality L75

on north side of knoll about 100' south of sharp bend in road and $300^{\prime}$ 'south of South Fork Bridge, $\mathrm{SW}^{\frac{1}{4}}$, sec. $30, \mathrm{~T} .17 \mathrm{~S} ., \mathrm{R} .28 \mathrm{E}$.

(Imlay, 1973, p. 50). Approximately 250 feet (c. 76 meters) above the base of the Formation in the lower member.

Locality D: From the crest of the spur on the eastern flank of Schoolhouse Gulch just to the northeast

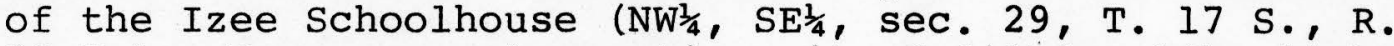
28 E.). From a conglomeratic unit of Silvies-like lithology, an estimated 1,850 stratigraphic feet (c. 560 meters) above the base of the Snowshoe Formation. This unit has been mapped as a marker horizon on the geologic map of Dickinson (1958). Only a few specimens of gastropods (marked Loc. D.) were collected from this locality and it is not, therefore, included in the check list (Table II).

Locality $E:$ On the south bank of a short draw on the

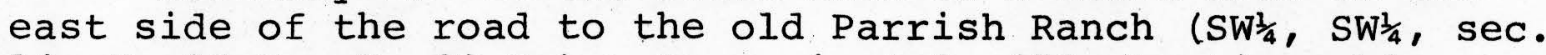
14, T. 17 S., R. 28 E.). Approximately 450 stratigraphic feet (c. 137 meters) below the top of the Formation (upper member) in an area of complex minor folds and faults. Specimens collected from this locality are marked "U. Sn. Loc. A". For the purposes of the check list (Table II), Localities $\mathrm{E}$ and $\mathrm{F}$ are treated as one.

Locality F: Probably the same as Dickinson's locality Dl15. From a large float field approximately 500 feet (c. 152 meters) southeast of Locality $\mathrm{E}$ (SW $\frac{1}{4}, \mathrm{SW}_{\frac{1}{4}}, \mathrm{sec} .14, \mathrm{~T}$. 17 S., R. 28 E.). Approximately 150 stratigraphic feet (c. 46 meters) below the top of the Formation (upper member) in an area of complex minor folds and faults. Specimens. 
collected from this locality are marked "U. Sn. Loc. B". For the purposes of the check list (Table II), Localities $E$ and $F$ are treated as one.

Locality G: In a road cut approximately 150 feet (c. 46 meters) south along the new Forest Service Road (number 1,612) from where the road bridges the Silvies

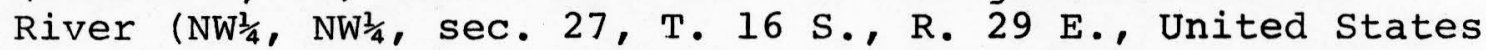
Department of the Interior, Bureau of Land Management map, 30 minute series, Izee). From lutite interbeds in the type area of the Silvies member of the Snowshoe Formation, 80 stratigraphic feet (c. 24 meters) above the base of the Member. Specimens collected from this locality are marked "F6-1". For the purposes of the check list (Table II), Localities $\mathrm{G}$ and $\mathrm{H}$ are treated as one.

Locality $\mathrm{H}$ : Approximately 150 feet (c. 46 meters) south along the new Forest Service Road Cut (road number 1,612) from Locality $G$, just north and opposite where Little Snowshoe Creek enters the Silvies River (township and range as for Locality $G$ above). From a coarse grained graywacke in the type Silvies Member of the Snowshoe Formation, 220 stratigraphic feet ( 67 meters) above the base of the Member. Specimens collected from this locality are marked "F6-2". As only one ammonite was collected (Lupherites senecaensis, Imlay), this locality is combined with Locality $G$ for the purposes of the check list (Table II). 


\section{APPENDIX B}

\section{FORTRAN IV PROGRAM STRAT}

Program Strat is a Fortran VI computer program written by the author for the IBM 1130 computer currently in use at Portland State University (1974 and 1975). Using data obtained from standard compass and tape surveys as described by Compton (1962, p. 239), the program may be used: (a) to obtain stratigraphic thickness figures for constructing a stratigraphic column and (b) to obtain the necessary information that will allow the exact stratigraphic position of a sample (lithologic or fossil) to be calculated in terms of feet above a chosen datum such as a contact.

Variables measured for each leg of the section are shown in fig. 20 .

\section{Mathematics}

Unfortunately, both the mathematics and the program itself are made more complicated by the absence of an arcsine function and a "logical if statement" in the IBM 1130 .

$$
\text { Given: } \quad \begin{aligned}
& A B=\text { SLDI } \\
& \quad A B D=\text { SLA }
\end{aligned}
$$




\begin{tabular}{|c|c|c|c|}
\hline $\begin{array}{l}\text { FORTRAN } \\
\text { NAME }\end{array}$ & DESCRIPTION & $\begin{array}{l}\text { REAL OR } \\
\text { INTEGER }\end{array}$ & $\begin{array}{l}\text { NO. OF } \\
\text { DECIMAL } \\
\text { PLACES }\end{array}$ \\
\hline DIP & $\begin{array}{l}\text { Angle of dip of the rocks (0 to } \\
90 \text { degrees). }\end{array}$ & Real & 0 \\
\hline DDIP & $\begin{array}{l}\text { Direction of dip of the rocks } \\
\text { ( } 0 \text { to } 360 \text { degrees; due north } \\
\text { taken as } 360 \text { degrees). }\end{array}$ & Real & 0 \\
\hline SLA & $\begin{array}{l}\text { Angle of slope between stations } \\
\text { ( } 0 \text { to } 90 \text { degrees). }\end{array}$ & Real & 2 \\
\hline DDSL & $\begin{array}{l}\text { Direction of downslope from } \\
\text { station ( } 0 \text { to } 360 \text { degrees; due } \\
\text { north taken as } 360 \text { degrees). }\end{array}$ & Real & 1 \\
\hline SLDI & $\begin{array}{l}\text { Length of leg, i.e. slope } \\
\text { distance (any linear units may } \\
\left.\text { be used to a maximum of } 10^{4}\right) \text {. }\end{array}$ & Real & 1 \\
\hline IUPDO & $\begin{array}{l}\text { A decision as to whether the } \\
\text { leg continues in the general } \\
\text { stratigraphic direction of the } \\
\text { section ( } i . e \text {. up or down the } \\
\text { succession) or whether it } \\
\text { repeats ground already covered. } \\
\text { zero denotes normal continua- } \\
\text { tion of the section whereas a } \\
\text { non-zero integer indicates } \\
\text { repetition. }\end{array}$ & Integer & -- \\
\hline
\end{tabular}

Figure 20. Variables for Program Strat.

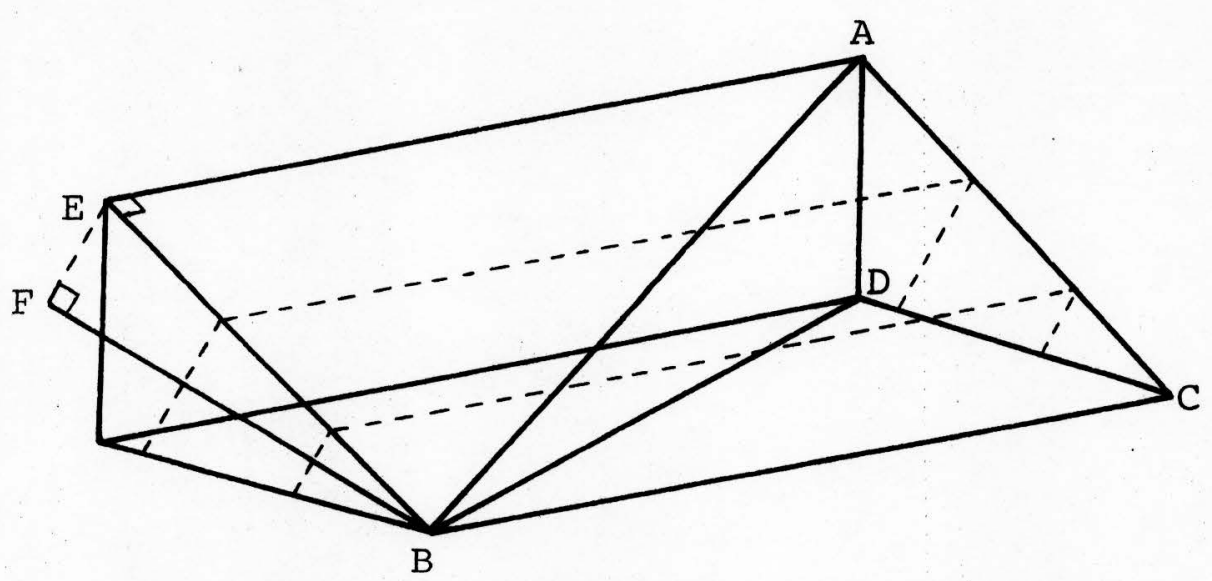

Figure 21. Model illustrating parameters used in Program Strat. 


$$
\begin{aligned}
& \text { Bearing } A \text { to } B=D D S L \\
& \text { Bearing } C \text { to } A=D D I P \begin{array}{l}
\text { (since } A E \text { is the } \\
\text { strike) }
\end{array}
\end{aligned}
$$

Required: Stratigraphic thickness $=\mathrm{FB}$

Method: $\quad|\mathrm{BAC}|=|\mathrm{DDIP}-\mathrm{DDSL}|=$ ANGA

Before making the necessary corrections to the slope angle and the slope (leg) distance, it can be shown that,

\begin{tabular}{|c|c|c|c|}
\hline \multirow[b]{2}{*}{$\begin{array}{l}\text { ANGA (IN } \\
\text { DEGREES) }\end{array}$} & \multirow[b]{2}{*}{ COMMENTS } & \multicolumn{2}{|c|}{ DIP AND SLOPE ARE:- } \\
\hline & & $\begin{array}{l}\text { IN THE SAME } \\
\text { DIRECTION }\end{array}$ & OPPOSED \\
\hline 0 & $\begin{array}{l}\text { No corrections to the } \\
\text { slope angle and distance } \\
\text { are required. }\end{array}$ & $\mathbf{x}$ & \\
\hline$(0,90)$ & $\begin{array}{l}\text { Use the corrections as } \\
\text { shown. }\end{array}$ & $\mathrm{x}$ & \\
\hline 90 & $\begin{array}{l}\text { No thickness has been } \\
\text { measured. }\end{array}$ & - & - \\
\hline$(90,180)$ & $\begin{array}{l}\text { ANGA }=180-\text { ANGA, then } \\
\text { use the corrections as } \\
\text { shown. }\end{array}$ & & $\mathrm{x}$ \\
\hline 180 & No corrections required. & & $\mathrm{x}$ \\
\hline$(180,270)$ & $\begin{array}{l}\text { ANGA }=\text { ANGA }-180 \text {, then } \\
\text { use the corrections as } \\
\text { shown. }\end{array}$ & & $\mathrm{x}$ \\
\hline 270 & $\begin{array}{l}\text { No thickness has been } \\
\text { measured. }\end{array}$ & - & - \\
\hline$(270,360)$ & $\begin{array}{l}\text { ANGA }=360-\text { ANGA, then } \\
\text { use the corrections as } \\
\text { shown. }\end{array}$ & $\mathrm{x}$ & \\
\hline
\end{tabular}
for the various possible values of ANGA, the conditions shown in fig. 22 hold true.

Figure 22. Program response to various values of ANGA. 
Corrections (sub-routine SLOPE)

To correct slope (leg) distance (AC):

$$
\mathrm{AC}=\mathrm{AB} \cdot \cos (\mathrm{ANGA}) \quad \begin{aligned}
& \text { (corrected slope distance } \\
& \text { designated CSLDI) }
\end{aligned}
$$

To correct the slope angle (SLA):

$$
\begin{gathered}
\sin (A B D)=\frac{A D}{\overline{A B}} \quad \begin{array}{l}
\text { therefore, } \\
A D=A B \cdot \sin (A B D)
\end{array} \\
\sin (A C D)=\frac{A D}{\overline{A C}}=\frac{A B \cdot \sin (A B D)}{A B \cdot \cos (A N G A)}=\frac{\sin (A B D)}{\cos (A N G A)} \\
A C D=\arctan \frac{\sin (A C D)}{\operatorname{SQRT}\left(1-\sin (A C D)^{2}\right)} \\
\text { (the corrected slope } \\
\text { angle is designated CSLA) }
\end{gathered}
$$

Once these corrections have been made, the formulae shown in Compton (1962, p. 241) may be used, viz. when the dip and slope are opposed:

If slope angle plus angle of dip is less than 90 degrees, then

$$
F B=A C \cdot \sin (D I P+A C D)
$$

If slope angle plus angle of dip is greater than 90 degrees, then

$$
\mathrm{FB}=\mathrm{AC} \cdot \sin (180-(\mathrm{DIP}+\mathrm{ACD}))
$$

When the dip and slope are in the same direction: If angle of dip is greater than angle of slope, then

$$
\mathrm{FB}=\mathrm{AC} \cdot \sin (\mathrm{DIP}-\mathrm{ACD})
$$

If angle of dip is less than angle of slope, then

$$
F B=A C \cdot \sin (A C D-D I P)
$$


DIMENSION A $(40)$

$\operatorname{READ}(2,72) \quad \mathrm{NTS}$

$\mathrm{K}=0$

DO $71 \mathrm{~J}=1$, NTS

$\operatorname{READ}(2,73)$ N1LEG , N2LEG , NSECT , JUPDO

WRITE $(5,74)$ NSECT

WRITE $(5,75)$

TSTTH $=0.0$

DO 60 I=N1LEG,N2LEG

$\mathrm{K}=\mathrm{K}+1$

$\operatorname{READ}(2,77)$ DIP , DDIP , SLA, DDSL , SLDI , IUPDO

WRITE $(5,78)$ DIP, DDIP , SLA, DDSL, SLDI

$S L A=S L A * .017453$

$\mathrm{DIP}=\mathrm{DIP}$ * 017453

$A N G A=A B S((D D I P-D D S L) * .017453)$

IF (ANGA) $20,17,20$

17 CSLDI $=$ SLDI

$\operatorname{CSLA}=S L A$

GO TO 42

20 IF (ANGA-1.570787) 22,22,21

21 IF (ANGA-1.570789) 24,27,27

22 CALL SLOPE (ANGA, SLDI, SLA, CSLDI, CSLA)

GO TO 42

$24 \mathrm{STTH}=0.0$

CONSC $=0.0$

GO TO 58

27 IF (ANGA-3.141575) 29,29,28

28 IF (ANGA-3.141577) 32,35,35

29 ANGA $=3.141576-\mathrm{ANGA}$

CALL SLOPE (ANGA, SLDI, SLA, CSLDI, CSLA)

GO TO 47

$32 \operatorname{CSLA}=S L A$

CSLDI $=$ SLDI

GO TO 47

35 IF (ANGA-4.712363) $37,37,36$

36 IF (ANGA-4.712365) $24,40,40$

37 ANGA $=$ ANGA -3.141576

CALL SLOPE (ANGA, SLDI, SLA, CSLDI, CSLA)

GO TO 47

40 ANGA $=6.283152-$ ANGA

CALL SLOPE (ANGA, SLDI, SLA, CSLDI, CSLA)

42 IF (DIP-CSLA) $43,24,45$

$43 \mathrm{STTH}=\mathrm{CSLDI}$ * SIN (CSLA-DIP)

GO TO 54

45 STTH=CSLDI* SIN (DIP-CSLA)

GO TO 54

47 IF ( (DIP+CSLA) -1.570787$) \quad 53,53,48$

48 IF ( (DIP+CSLA $)-1.570789) \quad 51,49,49$ 
49 STTH=CSLDI * SIN (DIP +CSLA)

GO TO 54

51 STTH=CSLDI

GO TO 54

$53 \mathrm{STTH}=\mathrm{CSLDI} * \operatorname{SIN}(3.141576-(\mathrm{DIP}+\mathrm{CSLA}))$

54 IF (IUPDO) $55,56,55$

$55 \mathrm{STTH}=\mathrm{STTH} *(-1$.

56 TSTTH=TSTTH + STTH

CONSC $=$ STTH $/$ SLDI

58 WRITE $(5,79)$ I, CONSC, STTH, TSTTH

$A(K)=S T T H$

60 CONTINUE

IF (JUPDO) $62,70,62$

$62 \operatorname{WRITE}(5,80)$

TOT $=0.0$

64 CONTINUE

$\mathrm{TOT}=\mathrm{TOT}+\mathrm{A}(\mathrm{K})$

$\mathrm{M}=\mathrm{N} 1 \mathrm{LEG}+(\mathrm{K}-1)$

WRITE $(5,82)$ M,TOT

$\mathrm{K}=\mathrm{K}-1$

IF (K) $64,71,64$

$70 \mathrm{~K}=0$

71 CONTINUE

72 FORMAT (I2)

73 FORMAT (4 I 4)

74 FORMAT $(1 \mathrm{H} 1,51 \mathrm{X}$, 'SECTION NUMBER ' , I $2, / /)$

75 FORMAT (4X, 'DIP' , 8X, 'DDIP' ,9X, 'SLA', 8X, 'DDSL' , 8X, 'SLDI' , 5X, 6 'LEG' , 5X, 'SCALE' , 7X, 'STRATIGRAPHIC INTERVAL' , 8X, 'TOTAL' )

77 FORMAT (5F6.0,I2)

78 FORMAT (2X,F5.1,7X,F6.1,6X,F6.2,6X,F6.1,6X,F6.1)

79 FORMAT $(60 \mathrm{X}, \mathrm{I3}, 5 \mathrm{X}, \mathrm{F} 6.3,13 \mathrm{X}, \mathrm{F} 8.1,10 \mathrm{X}, \mathrm{F} 10.1)$

80 FORMAT ( 1 HI,' UP SUCCESSION THICKNESSES',

615X, 'LEG' , 6X, 'TOTAL')

82 FORMAT ( $43 \mathrm{X}, \mathrm{I} 2,5 \mathrm{X}, \mathrm{F} 6.1)$

CALL EXIT

END

SUBROUTINE SLOPE (ANGA, SLDI , SLA, CSLDI , CSLA)

TERMI $=\operatorname{COS}($ ANGA $)$

CSLDI $=$ SLDI *TERMI

IF (SLA) $91,89,91$

89 CSLA $=$ SLA

GO TO 93

91 TERM2=SIN (SLA) /TERM1

CSLA =ATAN (TERM2/SQRT (1 -TERM2*TERM2) )

93 CONTINUE

RETURN

END 
Data Input

Cards are used for data input. As here written, Program Strat will deal with up to 99 sections with no limit as to the number of legs composing each section. The first card in the data stack states (using an

I2 format) how many sections are being run.

For each section, the first card contains four variables (using a 4 I4 format).

NILEG, N2LEG: The numbers of the starting and finishing legs which need not necessarily start at 1 but must always be consecutive integers.

NSECT: The number of the section; an integer used purely as a label.

JUPDO: An instruction as to whether the entire section is being run from the base up or vice versa. This is expressed in terms of the integer variable JUPDO which is zero if the section was run from the base of the succession up, and non-zero if it was run from the top down. In the latter case, the stratigraphic thicknesses and the total stratigraphic thickness are written out in the correct order on a separate sheet at the end of the main calculations. Following the initial card for each section is a card for every leg. Each card carries the six variables shown in fig. 20 (using a 5F6.0,I2 format). 
Data Output

The exact stratigraphic position of a fossil may be calculated using the conversion scale for that leg (CONSC in the program) and the preceeding stratigraphic thickness total. This is illustrated in the following examples:

(A)

$\begin{array}{cccc}\text { LEG } & \text { SCALE } & \begin{array}{c}\text { STRATIGRAPHIC } \\ \text { INTERVAL }\end{array} & \text { TOTAL } \\ & & & \\ 1 & 0.5 & 20 & 20 \\ 2 & 0.4 & 200 & 220 \\ 3 & 0.6 & 80 & 300\end{array}$

Assume a normal situation where the section was run from the base of the succession to the top. If a fossil was collected 80 feet along leg 2 , its position would be calculated as follows:

$$
\begin{aligned}
& \text { (Stratigraphic total }+((\text { Position }) \times \text { Scale })) \\
& \text { up to that leg) } \\
& =20+(80 \times 0.4)=52 \text { feet above the base. } \\
& \text { See fig. } 23 \mathrm{~A} .
\end{aligned}
$$

(B)

$\begin{array}{lcrrrr}\text { LEG } & \text { SCALE } & \begin{array}{c}\text { STRATIGRAPHIC } \\ \text { INTERVAL }\end{array} & \text { TOTAL } & \text { LEG } & \text { TOTAL } \\ & & & & & \\ 1 & 0.5 & 20 & 20 & 3 & 80 \\ 2 & 0.4 & 200 & 220 & 2 & 280 \\ 3 & 0.6 & 80 & 300 & 1 & 300\end{array}$

In this situation the section was run from the top of the succession to the base. The position of a fossil collected 80 feet along leg 2 is calculated using the figures in the two columns printed out after the main calculations but here tabulated together for convenience (the two right 


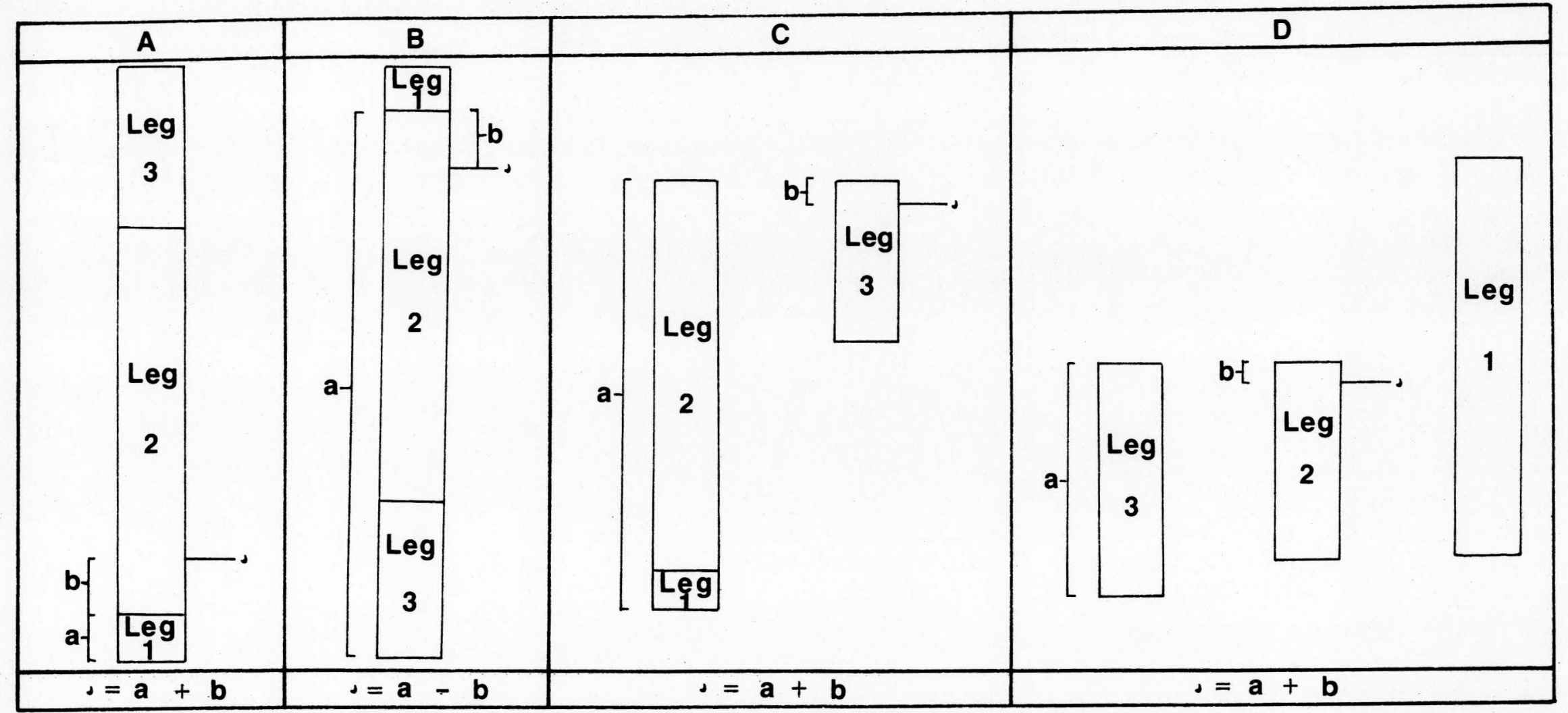

Key: $\quad$ Fossil position. $\left[50\right.$ feet a $=\begin{array}{l}\text { Stratigraphic } \\ \text { total. }\end{array}$

See text for discussion.

$\begin{aligned} \mathbf{b}= & \text { Position of } \\ & \text { fossil along leg } \\ & \text { multiplied by }\end{aligned}$ multiplied

Figure 23. Examples illustrating the calculation of fossil positions using Program Strat. 
hand columns).

$$
\begin{aligned}
& \text { (Stratigraphic total }-((\text { Position }) \times \text { Scale })) \\
& \text { up to that leg) } \\
& =280-(80 \times 0.4)=248 \text { feet above the base. }
\end{aligned}
$$$$
\text { See fig. 23B. }
$$

$\begin{array}{crcr}\text { LEG } & \text { SCALE } & \begin{array}{c}\text { STRATIGRAPHIC } \\ \text { INTERVAL }\end{array} & \text { TOTAL } \\ 1 & 0.5 & 20 & 20 \\ 2 & 0.5 & 200 & 220 \\ 3 & -0.6 & -80 & 140\end{array}$

This example illustrates the procedure to be adopted when it has been necessary to run a let (or legs) back across ground that has already been covered. Notice that the scale is negative. It is a situation where the section has been run from the base up and a fossil has been found 20 feet along leg 3 .

$$
\begin{aligned}
& \begin{array}{l}
\text { (Stratigraphic total } \\
\text { up to that leg })
\end{array} \\
& =220+(20 \times 0.6)=208 \text { feet above the base. } \\
& \text { See fig. } 23 \mathrm{C} .
\end{aligned}
$$

$\begin{array}{cccccr}\text { LEG } & \text { SCALE } & \begin{array}{c}\text { STRATIGRAPHIC } \\ \text { INTERVAL }\end{array} & \text { TOTAL } & \text { LEG } & \text { TOTAL } \\ 1 & 0.5 & 200 & 200 & 3 & 120 \\ 2 & -0.4 & -100 & 100 & 2 & 20 \\ 3 & 0.6 & 120 & 220 & 1 & 220\end{array}$

Finally, it could happen that a section was run from the top of the succession to the base and it was necessary to double back across already covered ground. Using the 
two right hand columns, as for example (2), the position of a fossil collected 40 feet along leg 2 would be calculated as follows:

$$
\begin{aligned}
& \text { (Stratigraphic total }+(\text { (Position) } \times \text { (Scale)) } \\
& \text { up to that leg) } \\
& =120+(40 \times 0.4)=110 \text { feet above the base. }
\end{aligned}
$$

See fig. 23D. 
APPENDIX C

FOSSIL CATALOG NUMBERS

Each fossil collected from a measured section bears a three part catalog number, with a letter prefix that will yield information as to the specimen's geographic and relative stratigraphic position. The initial letter denotes whether the sample was collected for its fossil content (F) or its value as a hand specimen (L). Samples that were not found in situ are preceeded by the word "Float". The first number in the sequence is the section number (see fig. 1). The second number is that of the legs which comprise the section. On Sections 3, 4 and 5 this is a measure of the relative stratigraphic position since the sections were measured from the base of the sequence to the top without repetition. This is not the case on section 1 which was measured from the top to the base and on section 2, which meandered up and down the sequence, across the strike of unit. The third number is unique to that particular specimen and is sequential along that leg.

Where a sample yielded more than one fossil, further numbers in parentheses were added as necessary. External and internal molds, or fragments of the same specimen are 
differentiated using suffixed letters.

For specimen numbers used for each of the Localites

A through $\mathrm{H}$, consult the locality descriptions (Appendix A).

The majority of the specimens and rubber casts are deposited at the Earth Sciences Museum, Portland State University except for selected specimens that are to be deposited in the United States National Museum, Washington, D. C. 